UNIVERSIDADE DE SÃO PAULO

FACULDADE DE ECONOMIA, ADMINISTRAÇÃO E CONTABILIDADE DEPARTAMENTO DE CONTABILIDADE E ATUÁRIA PROGRAMA DE PÓS-GRADUAÇÃo EM CIÊNCIAS CONTÁBEIS

\author{
A PRÁTICA DA CONTROLADORIA NOS MAIORES BANCOS \\ QUE OPERAM NO BRASIL À LUZ DE UMA ESTRUTURA \\ CONCEITUAL BÁSICA DE CONTROLADORIA
}

Bleise Rafael da Cruz

Orientador: Prof. Dr. Iran Siqueira Lima

SÃO PAULO 


\section{Prof. ${ }^{a}$ Dr. ${ }^{a}$ Suely Vilela \\ Reitora da Universidade de São Paulo \\ Prof. Dr. Carlos Roberto Azzoni}

Diretor da Faculdade de Economia, Administração e Contabilidade

Prof. Dr. Fabio Frezatti

Chefe do Departamento de Contabilidade e Atuária

Prof. Dr. Edgard Bruno Cornachione Junior

Coordenador do Programa de Pós-Graduação em Contabilidade 


\title{
A PRÁTICA DA CONTROLADORIA NOS MAIORES BANCOS QUE OPERAM NO BRASIL À LUZ DE UMA ESTRUTURA CONCEITUAL BÁSICA DE CONTROLADORIA
}

\author{
Dissertação apresentada ao Departamento de \\ Contabilidade e Atuária da Faculdade de \\ Economia, Administração e Contabilidade da \\ Universidade de São Paulo como requisito \\ para a obtenção do título de Mestre em \\ Ciências Contábeis.
}

Orientador: Prof. Dr. Iran Siqueira Lima

\section{SÃO PAULO}


FICHA CATALOGRÁFICA

Elaborada pela Seção de Processamento Técnico do SBD/FEA/USP

Cruz, Bleise Rafael da

A prática da controladoria nos maiores bancos que operam no Brasil à luz de uma estrutura conceitual básica de controladoria / Bleise Rafael da Cruz. -- São Paulo, 2009.

$145 \mathrm{p}$.

Dissertação (Mestrado) - Universidade de São Paulo, 2009.

Bibliografia.

1. Controladoria 2. Bancos 3. Instituições financeiras I. Universidade de São Paulo. Faculdade de Economia, Administração e Contabilidade II. Título.

CDD -658.151 
À minha família que sempre me apoiou. 

Em primeiro lugar, agradeço a Deus por ter me concedido força e coragem para concluir este grande desafio em minha vida, não me desamparando nos momentos mais difíceis e me proporcionando grandes vitórias.

Aos meus pais, Maurílio e Leida, o meu muito obrigado por toda a dedicação, colaboração e compreensão nesse período de quase três anos, ajudando-me nos momentos de dificuldades e compartilhando comigo os momentos de alegria.

Ao meu orientador, Professor Dr. Iran Siqueira Lima, por me acompanhar desde a graduação, por aceitar me orientar no mestrado e na construção deste trabalho. Sou muito grato pela oportunidade de aprendizado que me foi proporcionada e pela sua atenção e disposição nesse período.

Aos Professores Drs. Wellington Rocha e Márcio Borinelli, os meus sinceros agradecimentos pelas preciosas sugestões e contribuições, que permitiram o desenvolvimento desta pesquisa e por estarem sempre à disposição para me ajudar em quaisquer dúvidas.

Ao Professor Dr. Cláudio Parisi por ter aceitado participar da banca examinadora e, especialmente, por suas contribuições no exame de qualificação desta dissertação.

Aos Professores Drs., que muito contribuíram para o meu conhecimento no mestrado: Ariovaldo dos Santos, Gilberto de Andrade Martins, Luiz Nelson Carvalho, Luiz João Corrar, Fábio Frezatti e Reinaldo Guerreiro.

Ao Jorge Bispo, não há palavras para agradecer as inúmeras revisões deste entre outros trabalhos, com as valiosas críticas, sugestões e, principalmente, a paciência e a amizade nesse período.

Agradeço, em especial, aos meus amigos Gerlando Lima, Tatiana Lopes e Zé Elias, que sempre me ajudaram nos trabalhos e artigos das diversas disciplinas.

Ao Banco Itaú, pelo suporte fundamental que me foi dado, para que eu conseguisse conciliar minha atividade profissional e acadêmica durante o meu mestrado, em especial a Isabel C. Lopes, Gustavo Piva, Marco Antunes, Marcos A. Machado e Abel P. Martins. Os meus agradecimentos, também, aos demais colegas de trabalho, que me ajudaram a crescer profissionalmente e adquirir um grande conhecimento nesses anos de banco.

Aos meus amigos dos cursos de Mestrado e Doutorado da FEA/USP: Adriana, Aldomar, Ana Luísa, Artur, Bruna, Bruno Souza, Camila, Carlos, Chiqueto, Cristiane, Cynthia, Daniel, Edilmar, Eric, Fabi, Gustavo, Luciane, Márcia, Mauricio, Murcia, Mychelle, 
Ricardo, Yara e outros. Tanto nos momentos difíceis de estudos na Sala 13, quanto nas baladinhas, sempre promovidas pela Ca e My (as baladeiras)... Vocês foram demais! Meus agradecimentos aos competentes e atenciosos colaboradores do EAC/FEA/USP, especialmente à Cris e ao Rodolfo, por todas as informações e auxílios. Também, agradeço aos funcionários da equipe "Melhores e Maiores", que trabalham no FEA 3, pela ajuda fornecida à minha pesquisa.

Ao Prof. Dr. Edgard Cornachione Jr. e aos colaboradores do UPD da Fipecafi, em especial ao Fabio Kobata, por terem viabilizado o questionário on-line desta dissertação, no site da Fipecafi.

O meu muito obrigado aos participantes desta pesquisa, que disponibilizaram seu valioso tempo, respondendo às entrevistas ou aos questionários. Sem vocês, seria impossível a conclusão deste trabalho.

A todos os meus amigos e a todos aqueles que, de alguma forma, contribuíram para o resultado final desta dissertação. 


\section{RESUMO}

A melhoria de processos e práticas de gestão tornou-se essencial aos bancos que operam no Brasil, em presença da rápida evolução das atividades econômicas e do mercado de crédito. Diante disso, a Controlaria, bem como as informações por ela disponibilizadas, ganha mais espaço e importância nas instituições financeiras. Nesse sentido, este trabalho teve como principal objetivo verificar se, e em que medida, as práticas de Controladoria dos maiores bancos que operam no Brasil se refletem em uma Estrutura Conceitual Básica de Controladoria (ECBC). Dessa forma, realizou-se uma revisão da ECBC proposta por Borinelli (2006), com uma complementação das funções e atribuições da Controladoria voltadas para instituições financeiras, de acordo com literatura específica sobre esse assunto. Também foi realizada uma pesquisa empírica, a qual se utilizou de entrevistas e questionários, para investigar a aplicação da teoria na prática de Controladoria dos maiores bancos que operam no Brasil, bem como uma análise da aderência dessas práticas à ECBC. No que diz respeito aos achados deste trabalho, quanto às funções gerais da Controladoria atribuídas pela ECBC, verificou-se que as funções de Contabilidade Societária, Contabilidade Fiscal, Gestão das Informações e Atendimento a Usuários Externos, são funções típicas da área de Controladoria nos bancos pesquisados, o que está aderente às recomendações feitas pela ECBC. Entretanto, as funções de Riscos, Controles Internos e Finanças não foram apresentadas pelos bancos pesquisados como desempenhadas pela área de Controladoria, sendo essas inconsistentes com a sistematização da ECBC. Além das funções gerais, este trabalho, igualmente, investigou o papel da Controladoria em processos específicos nas instituições financeiras. As respostas obtidas mostraram que, para os processos de Orçamento, Mensuração, Análise e Controle de Custos, bem como no Planejamento Tributário, a Controladoria é considerada como a área responsável ou coordenadora. Porém, para os processos de Planejamento Estratégico, Análises de Ambientes e Viabilidades, Avaliação de Desempenho e Controle de Riscos, a Controladoria não é considerada como responsável ou coordenadora desses processos e, em muitos casos, apenas fornece apoio/suporte informacional, não aderindo à ECBC. Não obstante, optou-se, ainda, por estratificar os dados obtidos entre diferentes grupos de instituições, o que permitiu realizar uma comparação da prática de Controladoria entre os grupos distintos. $\mathrm{O}$ que se encontrou, nessas estratificações, foi que a prática de Controladoria de alguns grupos parece ser mais aderente aos elementos que integram a ECBC, do que em outros grupos, sem que, entretanto, algum grupo pudesse refletir, completamente, esses elementos na prática. Por fim, conclui-se que os resultados encontrados evidenciaram que as práticas de Controladoria dos maiores bancos que operam no Brasil refletem, parcialmente, os elementos que integram uma Estrutura Conceitual Básica de Controladoria. 


\begin{abstract}
Improving management practices and processes has become an essential need for banks operating in Brazil, due to the fast-paced evolution of the economic activities and the credit market. In this context, Controllership, as well as the information it provides, has gained increased importance and prominence within financial institutions. In this sense, the main goal of this paper is to verify if and to what extent Controllership practices adopted by major banks in Brazil reflect a Basic Conceptual Structure of Controllership (Estrutura Conceitual Básica de Controladoria - ECBC). To that end, a revision of the ECBC proposed by Borinelli (2006) was carried out, including Controllership functions and duties aimed at financial institutions, as per the specific literature on this topic. An empirical research was also conducted through interviews and questionnaires in order to investigate and analyze how Controllership practices in major banks with operations in Brazil reflect the theory and adhere to the ECBC. The findings of this paper regarding general Controllership functions laid out by the ECBC reveal that Corporate Accounting, Tax Accounting, Information Management and External User Service are typical activities for the Controllership area in the banks investigated, which complies with the ECBC recommendations. On the other hand, functions regarding Risks, Internal Controls and Finances were found not to integrate the activities performed by the Controllership area in the banks investigated, which is inconsistent with the concepts systematized under the ECBC. In addition to the general functions, this paper also investigates the role Controllership plays in specific processes within financial institutions. The answers given reveal that Controllership is considered to be the area that leads and coordinates processes as Budgeting, Measurement, Costs Analysis and Control, as well as Tax Planning. However, Controllership is not considered to be the area that leads and coordinates processes regarding Strategic Planning, Environment and Viability Analyses, Performance Assessment and Risk Control, simply providing information support in many cases and thereby not adhering to the ECBC. Furthermore, there was an attempt to stratify the data obtained into different groups of institutions, which enabled a comparison of the Controllership practices across the groups. These categories showed that the Controllership practices of some groups seem to be more consistent with the ECBC elements than others, which does not indicate that any group could fully reflect these elements in practice. Finally, the results support the conclusion that Controllership practices in major banks operating in Brazil partially reflect the elements that comprise the Basic Conceptual Structure of Controllership.
\end{abstract}




\section{SUMÁRIO}

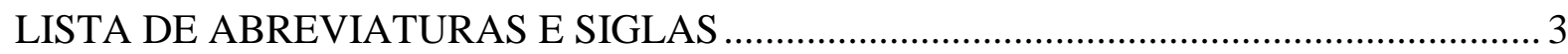

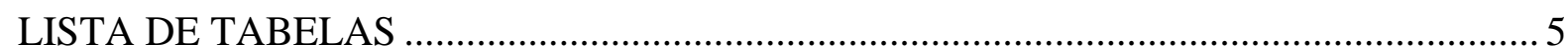

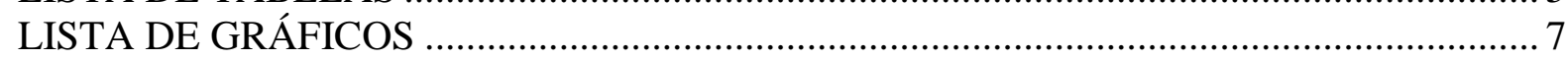

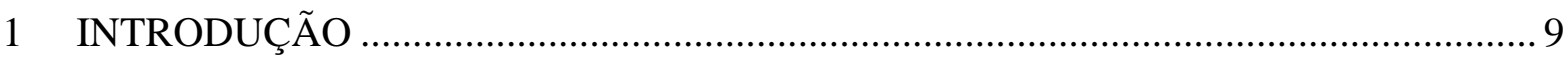

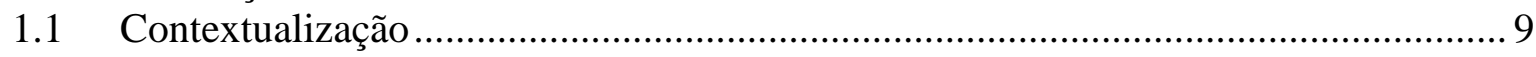

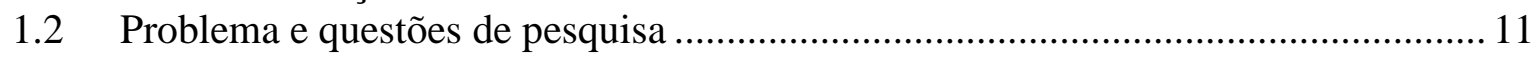

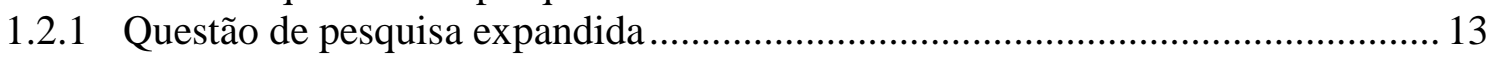

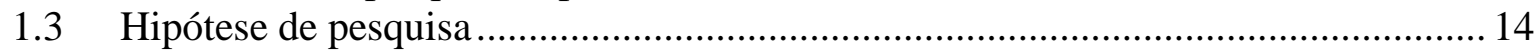

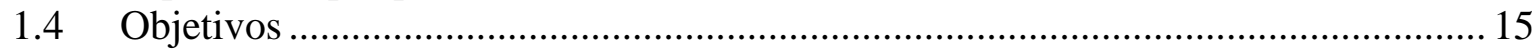

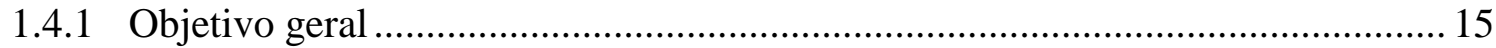

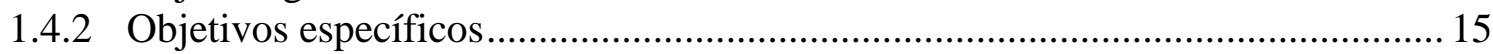

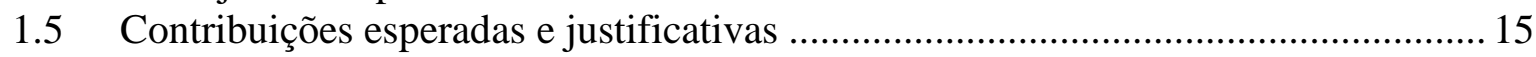

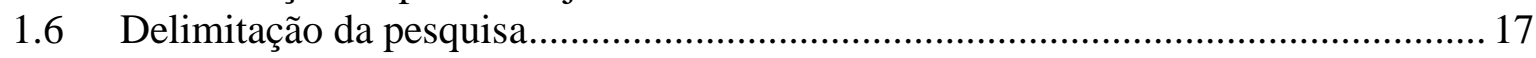

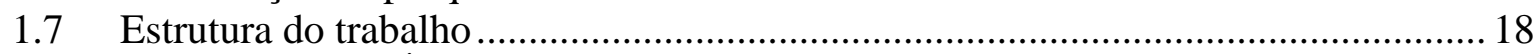

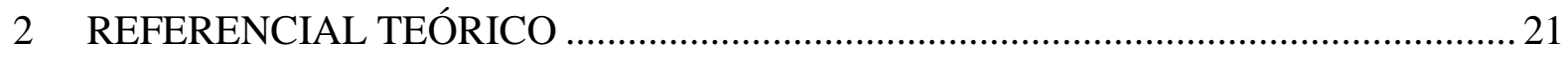

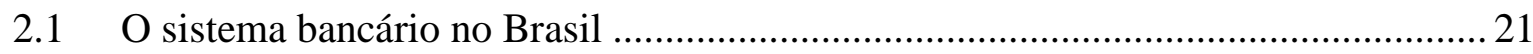

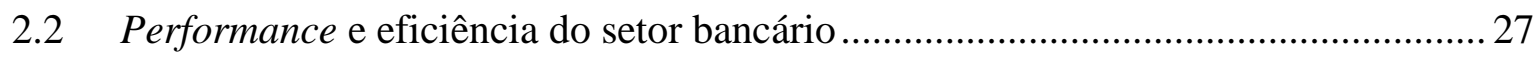

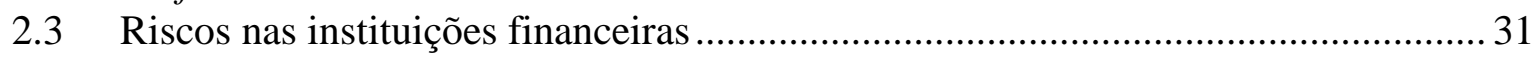

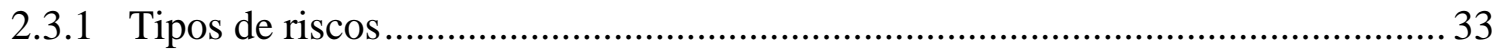

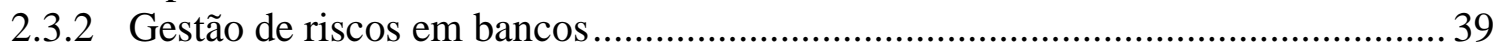

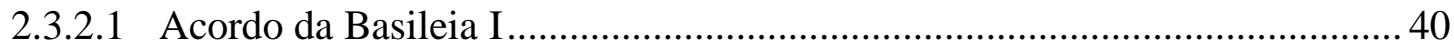

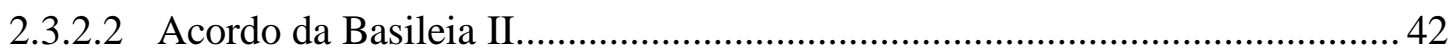

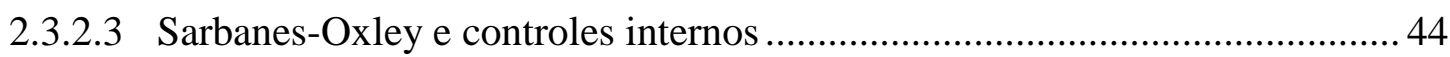

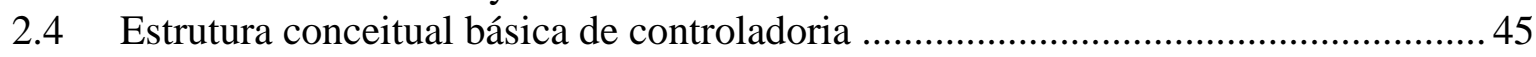

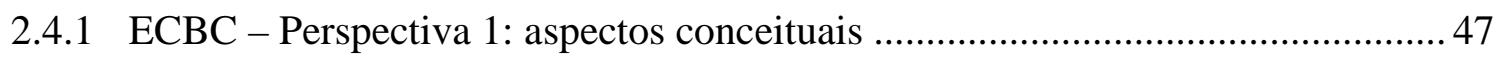

2.4.2 ECBC - Perspectiva 2: aspectos procedimentais ............................................ 48

2.4.2.1 Atividades e funções da controladoria no processo de gestão ....................... 51

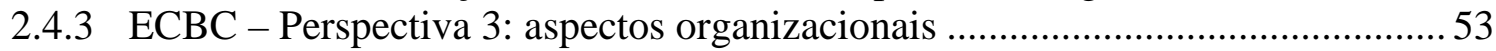

2.4.4 Funções e atribuições da controladoria em bancos ........................................... 56

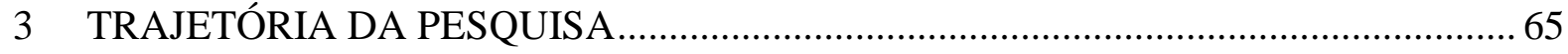

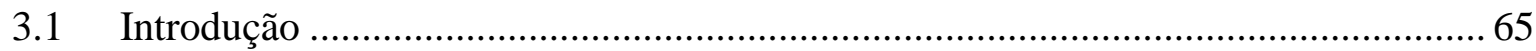

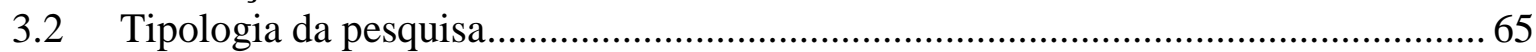

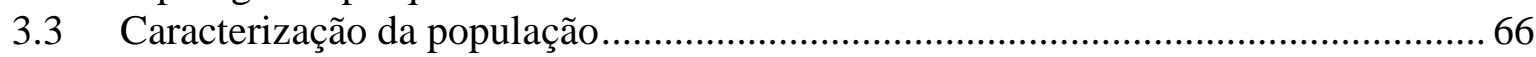

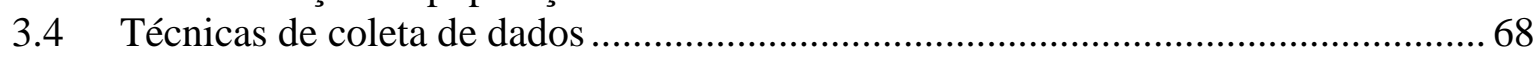

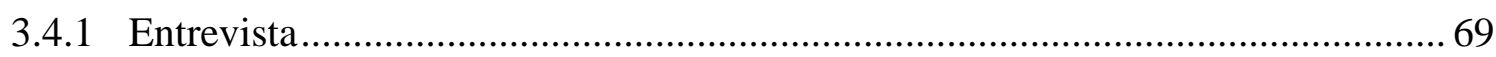

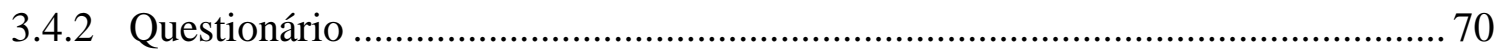

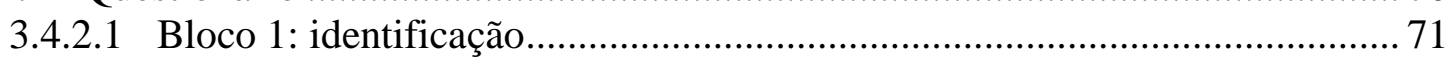

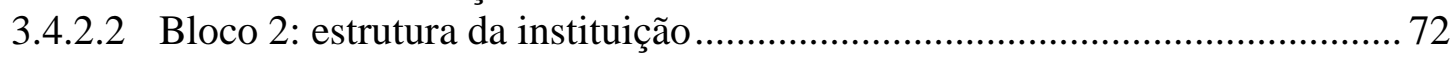

3.4.2.3 Bloco 3: identificação da unidade organizacional que exerce funções

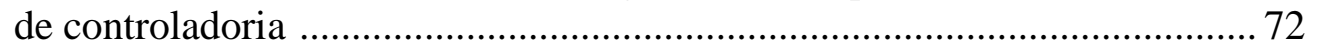

3.4.2.4 Bloco 4: identificação do profissional da principal unidade de

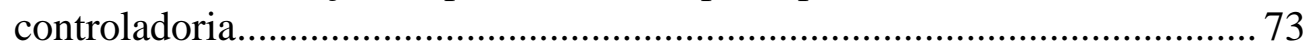

3.4.2.5 Bloco 5: estrutura da controladoria na instituição...................................... 73

3.4.2.6 Bloco 6: funções, atribuições e atividades da controladoria ......................... 74

3.4.2.7 Bloco 7: papel desempenhado pela controladoria em processos

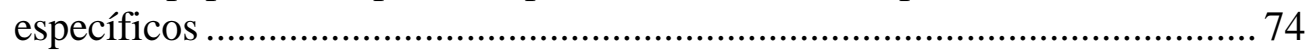

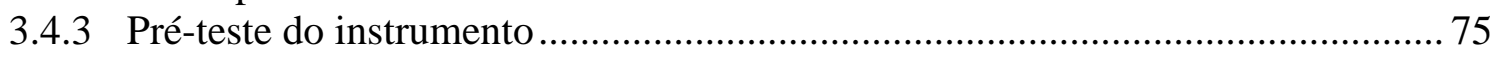




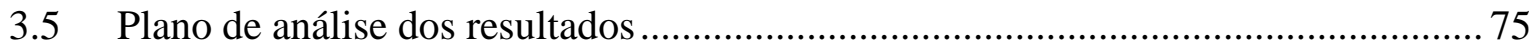

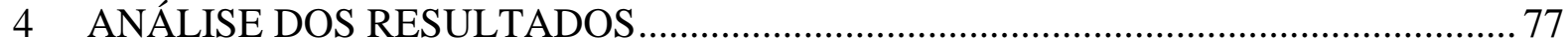

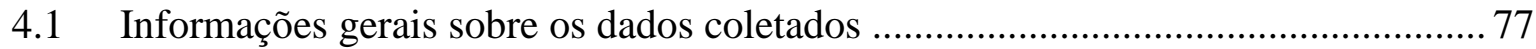

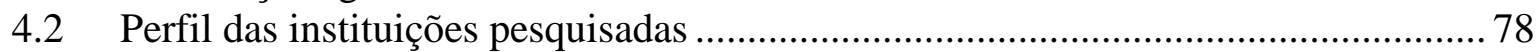

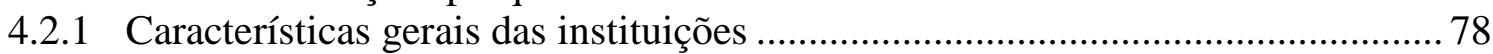

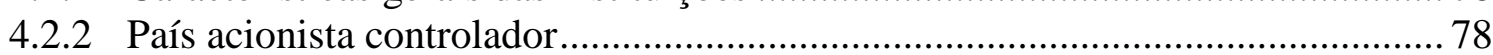

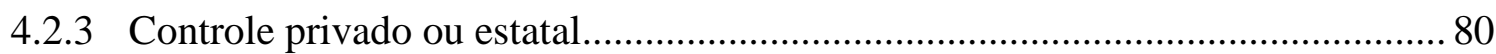

4.3 Análise e interpretação das práticas de controladoria nos bancos pesquisados ......... 80

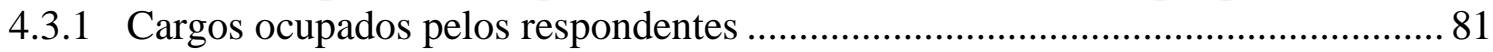

4.3.2 Identificação da unidade organizacional que exerce funções de controladoria ... 83

4.3.3 Identificação do profissional da principal unidade de controladoria .................. 88

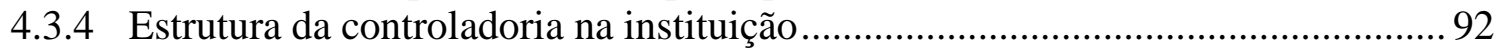

4.3.5 Funções, atribuições e atividades da controladoria ............................................ 94

4.3.6 Papel desempenhado pela controladoria em processos específicos ..................... 104

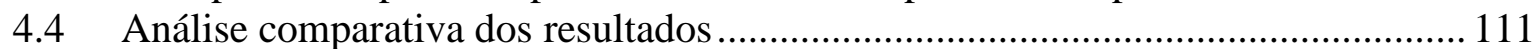

4.4.1 Estratificação 1: sete maiores bancos participantes e demais bancos ................. 112

4.4.2 Estratificação 2: bancos de capital nacional e de capital estrangeiro ................... 116

4.4.3 Estratificação 3: bancos privados e bancos estatais ........................................ 120

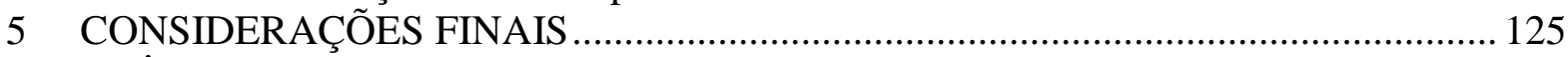

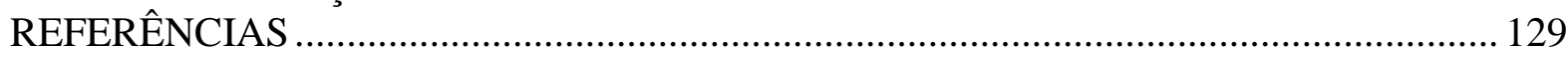

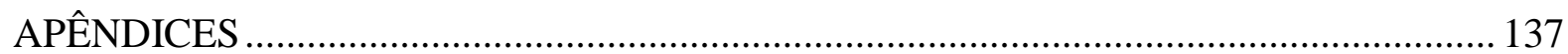


LISTA DE ABREVIATURAS E SIGLAS

\author{
ABC: Activity Based Costing \\ BACEN: Banco Central do Brasil \\ BIS: Bank for International Settlements \\ CDB: Certificado de Depósito Bancário \\ CEO: Chief Executive Officer \\ CFO: Chief Financial Office \\ CGPC: Conselho de Gestão de Previdência Complementar \\ CMN: Conselho Monetário Nacional \\ CNSP: Conselho Nacional de Seguros Privados \\ CVM: Comissão de Valores Mobiliários \\ ECBC: Estrutura Conceitual Básica de Controladoria \\ FEBRABAN: Federação Brasileira de Bancos \\ FGTS: Fundo de Garantia do Tempo de Serviço \\ INSS: Instituto Nacional de Seguridade Social \\ MBA: Master of Business Administration \\ PL: Patrimônio Líquido \\ RDB: Recibo de Depósito Bancário \\ ROA: Retorno Sobre o Ativo \\ ROE: Retorno Sobre o Patrimônio Líquido \\ SFN: Sistema Financeiro Nacional \\ SUSEP: Superintendência de Seguros Privados \\ SPC: Secretaria de Previdência Complementar \\ TI: Tecnologia da Informação
}





\section{LISTA DE TABELAS}

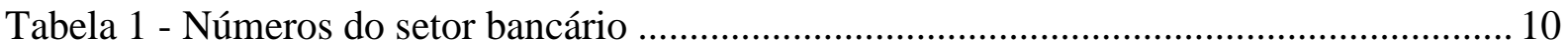

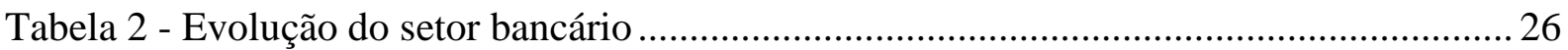

Tabela 3 - Exemplo de fatores de risco ......................................................................... 42

Tabela 4 - Resumo das atividades de controladoria mais citadas, segundo a literatura........... 49

Tabela 5 - Principais funções da controladoria para bancos ................................................59

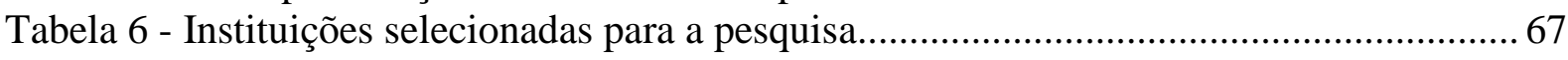

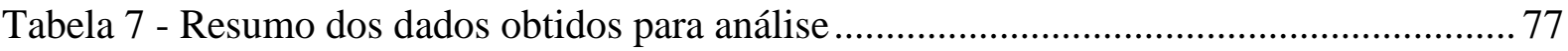

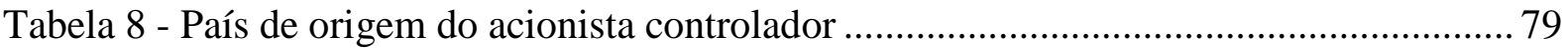

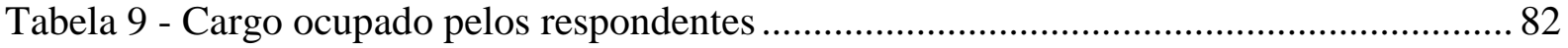

Tabela 10 - Denominação da unidade que exerce as funções de controladoria ........................ 84

Tabela 11 - Cargo do responsável pela unidade organizacional de controladoria .................... 85

Tabela 12 - Agrupamento do cargo do esponsável pela unidade organizacional

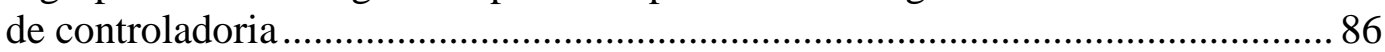

Tabela 13 - Quantidade de órgãos denominados controladoria ............................................. 87

Tabela 14 - Segmentação da controladoria por produtos ou serviços do banco ....................... 87

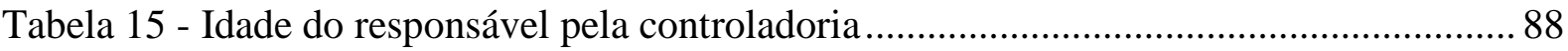

Tabela 16 - Formação de graduação do responsável pela controladoria...................................89

Tabela 17 - Formação de pós-graduação do responsável pela controladoria............................ 90

Tabela 18 - Tempo do colaborador responsável pela controladoria na empresa e na função.. 90

Tabela 19 - Responsável pela controladoria: contratado ou transferido para a função............ 92

Tabela 20 - Unidades formalmente constituídas na controladoria ......................................... 93

Tabela 21 - Outras unidades formalmente constituídas na controladoria ............................... 94

Tabela 22 - Atividades da função contabilidade societária .................................................95

Tabela 23 - Atividades da função contabilidade fiscal ....................................................... 96

Tabela 24 - Atividades da função riscos e controles internos .................................................. 98

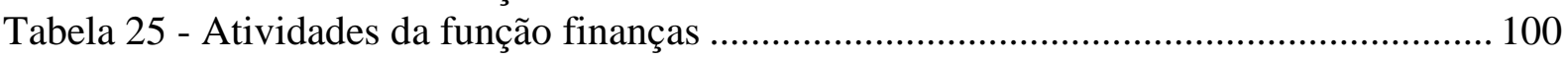

Tabela 26 - Atividades da função gestão das informações ................................................... 101

Tabela 27 - Atividades da função atendimento a usuários externos ...................................... 102 



\section{LISTA DE GRÁFICOS}

Gráfico 1 - Número de bancos no período de 1996 a 2007...................................................... 25

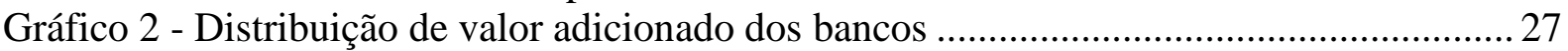

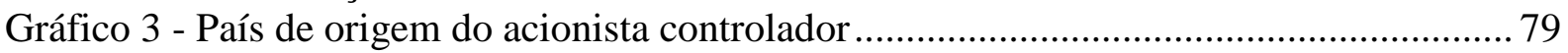

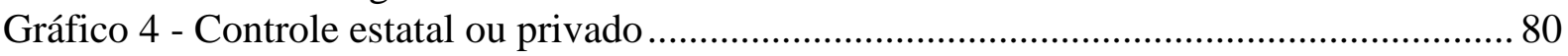

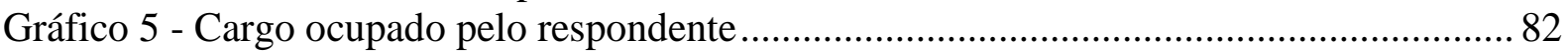

Gráfico 6 - Existência de unidade denominada controladoria ............................................... 83

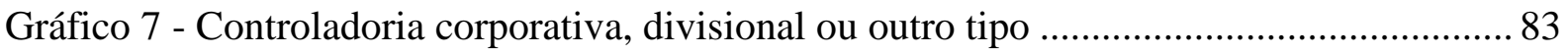

Gráfico 8 - Denominação da unidade que exerce as funções de controladoria........................ 84

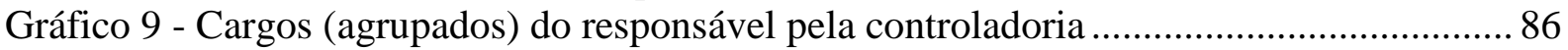

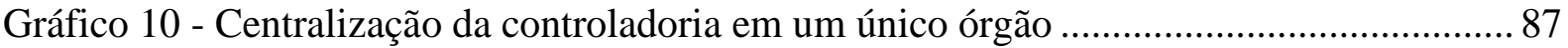

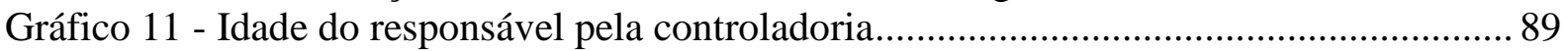

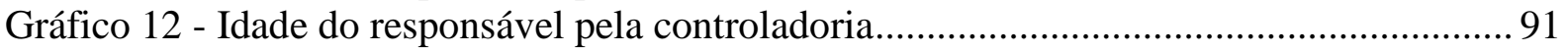

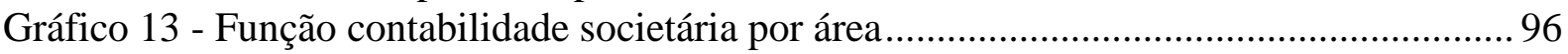

Gráfico 14 - Função contabilidade fiscal por área .............................................................. 97

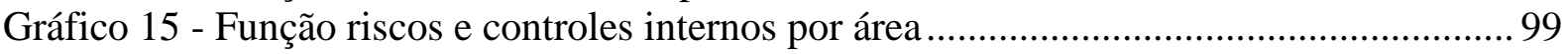

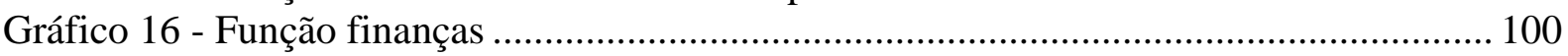

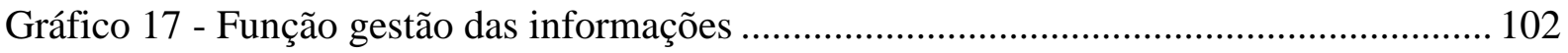

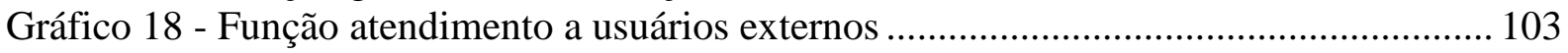

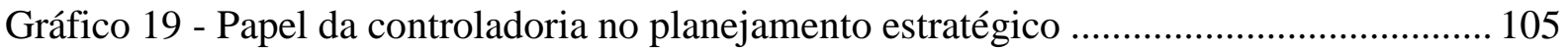

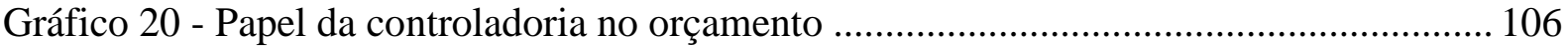

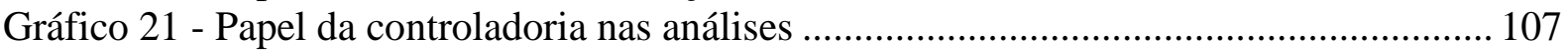

Gráfico 22 - Papel da controladoria na avaliação de desempenho........................................ 108

Gráfico 23 - Papel da controladoria na mensuração, análise e controle de custos.................. 109

Gráfico 24 - Papel da controladoria no planejamento tributário .......................................... 110

Gráfico 25 - Papel da controladoria no controle de riscos .................................................. 111

Gráfico 26 - Funções gerais da controladoria nos 7 maiores bancos pesquisados.................. 114

Gráfico 27 - Funções gerais da controladoria nos demais bancos ....................................... 115

Gráfico 28 - Funções gerais da controladoria nos bancos de capital nacional....................... 117

Gráfico 29 - Funções gerais da controladoria nos bancos de capital estrangeiro ................... 119

Gráfico 30 - Funções gerais da controladoria nos bancos privados ...................................... 121

Gráfico 31 - Funções gerais da controladoria nos bancos estatais ........................................ 123 



\section{INTRODUÇÃO}

\subsection{Contextualização}

As atividades econômicas, no Brasil, apresentam-se em uma rápida evolução nos últimos anos. Constantemente, surgem novas formas de organizações e novos tipos de negócios, atrelados a instrumentos financeiros cada vez mais arrojados. Com isso, as empresas precisam de novas e melhores práticas de gestão, melhoria nos seus processos e agilidade nas informações para si própria e para seus stakeholders. Dessa forma, a Controladoria ganha uma presença cada vez maior dentro das organizações, adaptando-se aos novos modelos de gestão e atendendo às necessidades dos usuários de suas informações.

Devido a essa crescente importância, o papel da Controladoria nas organizações é alvo de muita discussão. Diversos estudos apresentam análises sobre suas funções, atividades, responsabilidades e enquadramento dentro das empresas. (NASCIMENTO; REGINATO, 2007; CATELLI, 2001; KANITZ, 1976; NAKAGAWA, 1993; MOSIMANN; FISCH, 1999). O trabalho de Kanitz (1976) estabelece que a Controladoria representa uma evolução da Contabilidade, sendo um sistema cuja função é avaliar e controlar o desempenho das diversas divisões da empresa. Já Mosimann e Fisch (1999) abordam a Controladoria como um corpo de doutrinas e conhecimentos relativos à gestão econômica, podendo ser visualizada como um órgão administrativo ou uma área do conhecimento humano.

A produção científica no Brasil sobre Controladoria apresenta uma diversidade de conceitos entre vários trabalhos e autores. Algumas obras discutem custos, planejamento, controles internos sem apresentar, claramente, os conceitos e funções da Controladoria. Muitos trabalhos focam a Controladoria na Contabilidade Gerencial, organizada para monitorar atividades intraorganizacionais. Como exemplo, uma lacuna, nos trabalhos nacionais, é a não apresentação de funções como geração de informações para os agentes externos.

Tendo em vista que a maior parte das pesquisas sobre Controladoria propõe modelos para sua utilização, apresenta funções e discute sobre controles internos, percebe-se que, ainda, há um processo de evolução de modelos e teorias sobre o assunto, com um crescimento gradativo no desenvolvimento de trabalhos práticos, voltados para as rotinas reais das organizações. Dessa 
forma, torna-se importante unir a teoria e a prática, para consolidar o arcabouço teórico e analisar sua aplicabilidade, verificando como as companhias se utilizam da Controladoria na sua rotina de trabalho.

O trabalho desenvolvido por Borinelli (2006) buscou sistematizar o conhecimento sobre Controladoria, por meio de um levantamento de obras existentes sobre o tema, elencando as principais atividades e funções da Controladoria mencionada em cada trabalho. $\mathrm{O}$ autor desenhou um arcabouço teórico denominado Estrutura Conceitual Básica de Controladoria, doravante chamado de ECBC, e investigou a realidade das práticas de Controladoria das 100 (cem) maiores empresas privadas que operam no Brasil, segundo a Revista Exame - Melhores \& Maiores.

O ranking apresentado pela revista não inclui as instituições financeiras, por apresentarem características diferentes dos demais setores da indústria nacional. O fato de terem operações e números muito díspares das outras empresas, a inclusão dessas instituições poderia, no mínimo, ocasionar a perda do grau de comparabilidade e prejudicar o objetivo principal da pesquisa. Sendo assim, essas entidades não estão incluídas no estudo realizado por Borinelli (2006).

Verifica-se, pelos dados divulgados, que o setor financeiro brasileiro está assumindo uma posição cada vez mais importante para a economia e para a sociedade. A partir da década de 90 esse setor apresentou um grande crescimento, com o surgimento dos mais variados produtos e realização de operações cada vez mais arrojadas. Segundo relatório da FEBRABAN - Federação Brasileira de Bancos, divulgado no primeiro semestre de 2008, o Patrimônio Líquido dos bancos atingiu o montante de R \$ 185,9 bilhões em 2006, com um montante de 102,6 milhões de contas correntes. A Tabela 1 mostra alguns indicadores que podem reforçar tais afirmativas.

Tabela 1 - Números do setor bancário

\begin{tabular}{l|r|r|r|r}
\multicolumn{1}{c|}{ Item } & \multicolumn{1}{c|}{$\mathbf{2 0 0 3}$} & \multicolumn{1}{c|}{$\mathbf{2 0 0 4}$} & \multicolumn{1}{c|}{$\mathbf{2 0 0 5}$} & \multicolumn{1}{c}{$\mathbf{2 0 0 6}$} \\
\hline Ativos Totais Médios (em R\$ milhões) & 7.093 & 7.710 & 9.581 & 11.951 \\
\hline Patrimônio Líquido Médio (em R\$ milhões) & 882 & 964 & 1.093 & 1.447 \\
\hline Quantidade de dependências bancárias & 51.252 & 52.702 & 57.724 & 61.083 \\
\hline Fonte: Banco Central do Brasil
\end{tabular}

Fonte: Banco Central do Brasil 
No cenário atual, os bancos estão imersos em um ambiente altamente competitivo, sujeitos a instabilidades provocadas por situações políticas e econômicas, com suas operações dominadas pela informatização e um setor cada vez mais regulamentado. Com a atuação em diversos ramos do setor financeiro, os bancos estão sujeitos à regulamentação dos mais diversos órgãos nacionais e internacionais, tal como a Comissão de Valores Mobiliários (CVM), o Banco Central do Brasil (BACEN) e a Securities and Exchange Commission (SEC), além dos órgãos fiscais e reguladores a que estão sujeitos todas as empresas. Toda essa regulamentação e fiscalização acarretam grandes investimentos de recursos em controles internos.

Devido à importância dos bancos na economia nacional e à grande variedade de suas operações, a prática da Controladoria, nessas organizações, torna-se algo complexo e de difícil entendimento. Diversos estudos, no Brasil, apresentam análises sobre a Controladoria para instituições financeiras. Entretanto, os trabalhos com uma pesquisa empírica completa são escassos, sendo que, em sua grande maioria, focam seus estudos em funções específicas da Controladoria, tal como: auditoria interna, controles internos, avaliação de desempenho ou gestão econômica. (CARVALHO, 1995; GUERREIRO et al., 1997; FARIAS, 1998; BRITO, 2000; CHAGAS, 2000; PINHEIRO, 2000).

\subsection{Problema e questões de pesquisa}

Segundo Marconi e Lakatos (2005, p. 116), a teoria precisa ajustar-se aos fatos e, caso isso não ocorra, deve-se reformular essa teoria ou até mesmo rejeitá-la. Portanto, torna-se importante o desenvolvimento de trabalhos que apresentem um relacionamento entre a prática existente no mercado e a teoria científica. O sucesso dessa teoria depende do nível de sua aplicação na prática e de como será o seu comportamento ao ser colocada em uso.

A definição de funções e atividades da Controladoria é discutida em quase todos os trabalhos sobre esse tema. Para Nakagawa (1994, p. 44), a função pode ser considerada como “[...] uma agregação de atividades que têm um propósito em comum, como: compras, vendas, produção, marketing, finanças, segurança, qualidade etc." Para Borinelli (2006), a definição de atividades e funções apresentadas por Nakagawa (1994), é adequada para o estudo da ECBC, sendo a função um conjunto de atividades com propósitos comuns. 
As pesquisas mencionadas na seção anterior sobre Controladoria para instituições financeiras buscam entender a sua função e suas atividades dentro das entidades. Algumas tentam apresentar modelos teóricos para aplicação nesse ambiente, o perfil que se espera de um controller e atribuições da área. O problema é que estão focadas no aspecto normativo e, assim mesmo, divergem no conceito de Controladoria. Com isso, retrata-se uma fragilidade do arcabouço teórico sobre as discussões de Controladoria, dificultando a execução de trabalhos empíricos sobre o tema. Outras realizam estudos de uma função específica do papel da Controladoria, tal como gestão de resultados ou avaliação de desempenho, insuficientes para retratar a prática de uma forma geral.

Os trabalhos de Carvalho (1995), Pinheiro (2000) e Chagas (2000) contemplam análises da Controladoria em instituições financeiras, mas todos apresentando focos de estudos diferentes. Apesar da existência de alguns trabalhos sobre o tema, a divergência de informações encontradas nesses estudos desperta inquietações a respeito da prática da Controladoria nas instituições financeiras, principalmente sobre suas funções e como ela se materializa nessas entidades.

Carvalho (1995, p. 65) considera que “[...] a gestão econômica constitui o foco da preocupação da Controladoria [...]”. A partir dessa aceitação, o autor aborda, de maneira abrangente, os principais aspectos relacionados a essa visão de gestão econômica utilizada pela Controladoria para instituições financeiras organizadas sob a forma de bancos múltiplos. O trabalho foca a Controladoria como um órgão que exerce funções voltadas para a otimização dessa gestão, envolvendo sistemas de informações gerenciais para a tomada de decisões e auxílio às demais áreas na gestão de resultados.

O trabalho de Pinheiro (2000) aborda a atuação da Controladoria na definição, construção e no gerenciamento do modelo de avaliação de resultados e desempenhos, para que possa auxiliar no processo de tomada de decisões. Nesse trabalho, são apresentados os modelos para avaliação de resultados institucionais e como a Controladoria participa desse processo.

Chagas (2000), por sua vez, optou por ser mais abrangente, com foco nos aspectos gerais da Controladoria nas instituições bancárias com atuação no Brasil, abordando o perfil dos profissionais responsáveis pela área de Controladoria, as estruturas organizacionais, bem como as atribuições exercidas e as ferramentas utilizadas. $\mathrm{O}$ autor conclui sobre as funções 
que envolvem a Controladoria nessas entidades, considerando-as como um processo de feedback educativo, com um contínuo aprendizado da própria empresa e do seu ambiente.

O trabalho de Borinelli (2006) apresenta uma consolidação dos aspectos teóricos da Controladoria, verificando a aplicação dessa teoria na prática. Dessa forma, o autor desenvolveu um exercício científico formal, crítico e com uma pesquisa empírico-teórica estruturada. O objetivo desse trabalho foi verificar se, e em qual medida, os elementos que integram a ECBC refletem as práticas de Controladoria das 100 (cem) maiores empresas privadas que operam no Brasil. Uma limitação do estudo é o fato de não apresentar as instituições financeiras dentre as empresas analisadas.

Para Kerlinger (1980, p. 33-35), o problema científico é uma questão que precisa de discussão, investigação e decisão. Para o autor, os problemas científicos devem ser testados empiricamente. Ao considerar as características peculiares das instituições financeiras e a inexistência de um trabalho com semelhante forma de estudo, surge a necessidade do desenvolvimento de uma pesquisa dessa mesma natureza, procurando aplicar um exercício científico, por meio de uma estrutura empírico-teórica, verificando as maneiras como essas instituições refletem as práticas de Controladoria.

Dessa forma, com a finalidade de solucionar a situação-problema exposta acima, esta pesquisa apresenta a seguinte questão a ser discutida:

À luz de uma Estrutura Conceitual Básica de Controladoria, quais são os elementos que refletem a prática dos maiores bancos que operam no Brasil?

\subsubsection{Questão de pesquisa expandida}

Para que se possa responder à questão de pesquisa com maior propriedade, uma das alternativas é expandi-la em questões com detalhes específicos, com a finalidade de que essas possam contribuir para um melhor entendimento da questão geral. Além disso, as respostas obtidas para essas questões formam o caminho a ser seguido pelo trabalho e orientam os tópicos a serem discutidos. Logo, as questões expandidas a serem respondidas são as seguintes: 
i. Quais elementos devem integrar uma Estrutura Conceitual Básica de Controladoria para contemplar Instituições Financeiras?

ii. Quais são as práticas de Controladoria dos maiores bancos que operam no Brasil?

iii. Qual é o nível de aderência dos elementos da Estrutura Conceitual Básica de Controladoria nos maiores bancos que operam no Brasil?

\subsection{Hipótese de pesquisa}

Definido o problema e as questões de pesquisa, sobre o reflexo dos elementos que integram uma ECBC com as práticas de Controladoria pelos maiores bancos que operam no Brasil, uma provável solução é esperada. Martins e Theóphilo (2007, p. 31) expressam que:

\footnotetext{
A abordagem metodológica hipotético-dedutiva - comum nos estudos da área de humanidades pede o enunciado de hipóteses que no desenvolvimento do trabalho serão testadas e comprovadas através do suporte do referencial teórico e análises dos resultados de avaliações quantitativas e qualitativas das informações, dados e evidências conseguidas.
}

Conforme Gil (2002, p. 31), a hipótese pode ser a solução de um problema, sendo uma “[...] expressão verbal suscetível de ser declarada verdadeira ou falsa." Seguindo essa visão, apresenta-se a seguinte hipótese de pesquisa, que se caracteriza como uma provável solução ao problema de pesquisa já discutido anteriormente:

\section{As práticas de Controladoria dos maiores bancos que operam no Brasil refletem os elementos que integram uma Estrutura Conceitual Básica de Controladoria.}

Martins (1994, p. 32) afirma que, somente após a caracterização da situação-problema e da definição criteriosa da questão de pesquisa, se podem definir os objetivos de pesquisa. Dessa forma, após apresentar a questão de pesquisa, a questão expandida e a hipótese de pesquisa, a próxima seção tem por finalidade proporcionar os objetivos deste trabalho. 


\subsection{Objetivos}

Após a definição da questão de pesquisa e da hipótese para testar o problema, apresentam-se, nesse tópico, os objetivos da pesquisa. De acordo com Gil (2002, p. 111), “Os objetivos gerais são pontos de partida, indicam uma direção a seguir, mas, na maioria dos casos, não possibilitam que se parta para a investigação. Logo, precisam ser redefinidos, esclarecidos, delimitados. Daí surgem os objetivos específicos da pesquisa.”

Inicialmente, tem-se o Objetivo Geral, com uma visão global e abrangente sobre o tema. $\mathrm{Na}$ sequência, os Objetivos Específicos, atentando-se às características individuais do Objetivo, com um detalhamento mais específico, servindo de etapas para se alcançar o Objetivo Geral.

\subsubsection{Objetivo geral}

O objetivo geral desta pesquisa é verificar se, e em que medida, as práticas de Controladoria dos maiores bancos que operam, no Brasil, refletem uma Estrutura Conceitual Básica de Controladoria.

\subsubsection{Objetivos específicos}

Entre os objetivos específicos deste trabalho, têm-se:

i. Revisar os conceitos propostos por Borinelli (2006) para uma ECBC.

ii. Complementar a ECBC com foco em instituições financeiras.

iii. Investigar se ocorre uma aplicação da teoria da Controladoria, na prática, nos maiores bancos que operam no Brasil.

iv. Verificar a aderência dos maiores bancos que operam no Brasil à ECBC.

\subsection{Contribuições esperadas e justificativas}

Para que tenha aceitação, um trabalho científico deve apresentar suas justificativas. Conforme já evidenciado, a atividade bancária, no Brasil, está em crescente expansão, sendo um setor importante na economia do país, não só pelos aspectos quantitativos, mas pelo reflexo que 
ocasiona nos demais setores. O porte dessas empresas e a importância desse segmento justificam trabalhos acadêmicos que estudem suas formas de organização e outras características. Assim, a escolha desse segmento, como um objeto de estudo, pode ser benéfica em termos acadêmicos e empresariais.

Como já relatado, os trabalhos existentes, nessa área, têm abordagem e enfoques diferentes, voltados para a apresentação de modelos e elencando as funções da Controladoria. Poucos trabalhos científicos abordam a Controladoria, em seus diversos aspectos, aplicada aos Bancos. Com a falta dessas pesquisas que contemplem uma visão científica do relacionamento entre a Controladoria e sua aplicação nas práticas dos bancos, espera-se que este trabalho contribua para essa linha de estudos, apresentando uma relação científica e crítica desse relacionamento.

Outra justificativa é o reduzido número de trabalhos com enfoque sobre a prática da Controladoria em bancos, que contemplem uma visão capaz de dar respostas às questões de pesquisa aqui formuladas. O que se percebe é a falta de estudos capazes de reunirem uma plataforma teórica da Controladoria, com um estudo empírico nos bancos que operam no Brasil, tentando buscar as verdadeiras práticas de Controladoria dessas Instituições.

No meio acadêmico, o trabalho justifica-se por investigar a realidade de uma teoria na prática de um segmento de empresas no mercado. Dessa forma, este estudo apresenta uma Estrutura Conceitual Básica de Controladoria aplicada a bancos, num aspecto geral, com uma pesquisa empírico-teórica estruturada, não buscando demonstrar algumas características específicas como gestão de riscos ou avaliação de desempenho, mas, sim, com o objetivo de verificar a aderência dos bancos a essa estrutura, diferenciando-se dos demais trabalhos.

Para o mercado como um todo, este trabalho torna-se importante por apresentar a prática da Controladoria pelos maiores bancos que operam no Brasil, permitindo às companhias o conhecimento da realidade dessa prática e mensurar sua importância. Apesar da grande diferença entre o setor financeiro e os demais, principalmente nos seus indicadores, demonstrar a Controladoria praticada num ambiente sujeito a forte regulamentação pode servir de exemplo para outros setores, que poderão adotar melhores práticas nas suas atividades. 
As crescentes exigências dos órgãos reguladores das instituições financeiras, tal como CVM e BACEN, podem exigir certa melhoria nas atividades relacionadas à Controladoria dos Bancos. Para essas instituições financeiras, o estudo poderá ser utilizado como uma fonte para comparação do seu próprio método praticado de Controladoria, com relação às demais instituições e, até mesmo, identificar pontos que deverão ser incrementados.

\subsection{Delimitação da pesquisa}

Por tratar-se de um estudo que abrange diversos segmentos e com a finalidade de alcançar o objetivo proposto anteriormente, deve-se delimitar esta pesquisa. Segundo Martins e Teóphilo (2007, p. 5), um tema para estudo deve ser definido, ou seja, “[...] delimitar o assunto evitando-se enfoque genérico ou muito abrangente, tomando-se cuidado para não escolher um tema tão delimitado cuja solução se aproxime de resultados óbvios." Para os autores, ao ter um enfoque específico, foge-se das generalidades e repetições.

Para isso, esta pesquisa limitou-se a analisar a aplicação de uma Estrutura Conceitual Básica de Controladoria na prática dos maiores bancos que operam no Brasil, não se optando por estudar uma única fase da Controladoria nessas entidades, como, por exemplo, somente suas atividades ou funções. Este trabalho se propõe a estudar os diversos aspectos da Controladoria, baseando-se no estudo de Borinelli (2006, p. 37), que estrutura seu trabalho em “[...] três diferentes dimensões ou perspectivas da Controladoria: aspectos conceituais propriamente ditos (o que é Controladoria), aspectos procedimentais (quais são as suas atividades e funções) e aspectos organizacionais (como se aplica nas organizações).”

Não é foco deste trabalho, apresentar ou propor um modelo de Controladoria para os bancos que operam no Brasil. Deve-se deixar claro que não é o enfoque deste estudo oferecer soluções para as entidades que não aplicam o modelo teórico da Controladoria na prática. Não se analisam, também, possíveis ferramentas para a aplicação da Controladoria nas instituições ou formas alternativas para a aplicação da teoria.

A plataforma teórica desta pesquisa está apoiada na ECBC apresentada por Borinelli (2006), com uma revisão e crítica do seu conteúdo e, principalmente, com a adição de características para instituições financeiras na estrutura. Não está, no escopo deste trabalho, um 
levantamento histórico de conceitos da Controladoria, bem como uma discussão sobre a Controladoria ser uma ciência ou não.

Considerando-se o grande número de bancos no mercado nacional, houve a necessidade de delimitar a quantidade a ser pesquisada. Dentro do universo de bancos, foram selecionados os 50 (cinquenta) maiores bancos públicos e privados, por patrimônio, que operam no Brasil, de acordo com o ranking da edição Melhores e Maiores da Revista Exame, publicada em julho de 2008, com dados relativos a 2007. Dentre os bancos escolhidos, alguns são de capital aberto no Brasil, com ações negociadas na Bolsa de Valores de São Paulo (BOVESPA). Dessa forma, essas instituições destacam-se por terem boas práticas de Governança Corporativa e níveis de exigências dos órgãos regulamentadores praticamente iguais.

Dos 50 (cinquenta) bancos selecionados, a maioria deles é de controle acionário brasileiro, mas há, nessa seleção, um significativo número de bancos europeus e americanos. Desses bancos estrangeiros, não se procurou verificar a prática da Controladoria na matriz, mas, sim, na filial localizada no Brasil. Cabe destacar que, dentre os bancos de controle acionário brasileiro, alguns deles são de controle estatal.

Deve-se atentar para o fato que a base utilizada, neste trabalho, é do ano de 2007, conforme a publicação da Revista Exame, porém, as entrevistas e o envio dos questionários para essas instituições, foram realizados nos anos de 2008 e 2009. Durante esse período, ocorreram algumas mudanças com os bancos presentes na base de dados, tais como: fechamento de bancos, fusão e aquisições entre essas instituições. Portanto, apesar de utilizar uma base de dados de 2007, a pesquisa empírica deste trabalho apresenta a prática da Controladoria nesses bancos nos anos de 2008 e 2009.

\subsection{Estrutura do trabalho}

Este trabalho está organizado em cinco capítulos, direcionando a pesquisa a um encadeamento lógico. Inicia-se por essa introdução, em que consta uma breve contextualização dos trabalhos sobre Controladoria de uma forma geral e os relacionados às Instituições financeiras. Nessa introdução, apresenta-se: a questão de pesquisa, as hipóteses, os objetivos, as justificativas e as delimitações da pesquisa. 
O segundo capítulo trata da Plataforma Teórica que se inicia com uma revisão do arcabouço teórico da Controladoria. Faz-se uma revisão dos principais conceitos, funções e atividades da Controladoria existentes nas principais literaturas nacionais e estrangeiras. Mostram-se os estudos sobre Controladoria voltados para instituições financeiras e os trabalhos que buscam demonstrar como é a Controladoria na prática das empresas.

Na sequência, tem-se o capítulo de Metodologia do Trabalho, o qual apresenta a população e amostra utilizada pela pesquisa e os critérios usados para a seleção dos bancos pesquisados. As técnicas aplicadas para a obtenção das informações para a pesquisa foram questionários estruturados e entrevistas. Dessa forma, explicam-se, nessa seção, os motivos para a utilização de tais técnicas, bem como o proceder metodológico para colher os dados.

O capítulo 4 é dedicado a revelar os resultados da pesquisa, mediante questionários e entrevistas. Será apresentado o tratamento para as informações colhidas, bem como a interpretação das respostas das entrevistas e questionários respondidos. Procura-se, nesse capítulo, alinhar o arcabouço teórico revisado no capítulo dois com as informações obtidas na pesquisa, analisando, empiricamente, como a Controladoria é praticada nos maiores bancos que operam no Brasil.

Por fim, apresentam-se as considerações finais do trabalho: aborda-se o estudo como um todo e analisam-se as respostas encontradas para as questões propostas, com aceitação ou não da hipótese de pesquisa. Também, nessa seção, discutem-se as sugestões para possíveis pesquisas futuras. 



\section{REFERENCIAL TEÓRICO}

\subsection{O sistema bancário no Brasil}

Essa seção tem como objetivo fazer uma breve apresentação da estrutura do Sistema Financeiro Nacional (SFN), bem como as características do sistema bancário brasileiro. O SFN foi estruturado e regulado pela Lei de Reforma Bancária de 1964, Lei do Mercado de Capitais de 1965 e Lei de Criação dos Bancos Múltiplos de 1988. De acordo com a Lei da Reforma Bancária n. 4.595/64, as instituições financeiras são caracterizadas como “[...] pessoas jurídicas públicas ou privadas, que têm como atividade principal ou acessória a coleta, intermediação ou aplicação de recursos financeiros próprios ou de terceiros, em moeda nacional ou estrangeira, e a custódia de valor de propriedade de terceiros."

Segundo Andrezo e Lima (2007, p. 37), a Lei n. 4.595/64 “[...] reconfigurou completamente o SFN ao criar agentes normativos e determinar a área de competência de cada um." Além disso, a referida lei criou o Conselho Monetário Nacional (CMN) e o Banco Central do Brasil, determinando as competências de cada um, sendo o CMN o órgão responsável por formular e coordenar as políticas de moeda e do crédito e, o BACEN, o órgão responsável por sua execução e fiscalização.

A Constituição Federal de 5 de outubro de 1988 alterou o sistema que vinha funcionando desde 1964, incluindo, pela primeira vez, o Sistema Financeiro Nacional na Constituição Federal Brasileira. Sendo assim, Andrezo e Lima (2007, p. 164) definem que "O mercado financeiro foi considerado um sistema, ou seja, um conjunto de agentes que interagem entre si."

Para o bom funcionamento do mercado financeiro, tem-se uma regulação por entidades que integram o SFN. Lima et al. (2006, p. 16) elencam essas entidades, com as seguintes características:

a) Conselho Monetário Nacional (CMN): criado em 1964, sua função é exclusivamente deliberativa, sendo responsável por emitir diretrizes gerais para o bom funcionamento do SFN. Possui funções como: adaptar o volume dos meios de pagamento às reais 
necessidades da economia, regular valor interno e externo da moeda e o equilíbrio do balanço de pagamentos, orientar a aplicação dos recursos das instituições financeiras, entre outros.

b) Banco Central do Brasil (BACEN): autarquia, também, criada em 1964, com funções clássicas de emitir moeda e promover sua estabilidade interna e externa. Além disso, é responsável por manter a estabilidade do sistema financeiro nacional, regulamentando, supervisionando e fiscalizando as instituições financeiras.

c) Comissão de Valores Mobiliários (CVM): criada em 1976, com amplas atribuições no mercado de valores mobiliários, regulamentando, desenvolvendo, controlando e fiscalizando o setor. É sua função, igualmente, assegurar o funcionamento eficiente e regular dos mercados de bolsa e balcão e proteger os titulares de valores mobiliários.

d) Conselho Nacional de Seguros Privados (CNSP): foi criado em 1966, para fixar diretrizes e normas da política de seguros privados. Ficam sob sua responsabilidade: regular a constituição, organização, funcionamento e fiscalização das sociedades seguradoras, sociedades de capitalização, entidades de previdência privada aberta, resseguradoras e corretoras.

e) Superintendência de Seguros Privados (SUSEP): criada, também, em 1966, é responsável pela regulamentação e fiscalização do mercado de seguro, previdência privada aberta e capitalização.

f) Conselho de Gestão de Previdência Complementar (CGPC): foi criado, em 1978, para regular, normatizar e coordenar as atividades das entidades fechadas de previdência complementar.

g) Secretaria de Previdência Complementar (SPC): também criada em 1978, com competências como: fiscalizar, supervisionar, coordenar, orientar e controlar as atividades relacionadas com a previdência complementar fechada, examinando e aprovando os estatutos das entidades fechadas de previdência complementar. 
Segundo Assaf Neto (2006, p. 45):

As instituições financeiras podem ser classificadas em dois tipos: bancárias ou monetárias e não bancárias ou não monetárias. As instituições financeiras conhecidas por bancárias são aquelas a quem se permite a criação de moeda por meio do recebimento de depósito a vista [...]

No mercado financeiro brasileiro, predominam os bancos, que centralizam a oferta e a procura de capitais e atuam como parte na intermediação financeira.

Os bancos executam múltiplas funções que, em alguns casos, não se enquadrariam como funções de área financeira. Essas entidades estão sob a supervisão, regulamentação e fiscalização do BACEN, sendo classificadas de acordo com as atividades que exercem (FORTUNA, 2005, p. 27):

- Bancos Comerciais: a principal atividade é o recebimento de depósitos à vista em contas de movimento. Essas instituições podem efetuar empréstimos de curto e longo prazo a pessoas físicas e jurídicas, e, ainda, atuam na cobrança bancária mediante pagamento de taxas.

- Bancos de Desenvolvimento: sua principal função é o apoio financeiro às iniciativas econômicas regionais, por meio de empréstimos e financiamentos, em médio e longo prazos. São instituições regionais, estaduais ou federais, sob a forma de sociedade anônima.

- Bancos de Investimento: fornecem apoio financeiro às empresas por meio de financiamento para o suprimento de capital fixo ou de giro das empresas. Esse tipo de banco não pode manter conta-corrente e captam recursos por emissão de CDB e RDB, ou pela venda de cotas de fundos de investimentos por ele administrado.

- Bancos Múltiplos: esse tipo de instituição surgiu, em 1988, com a finalidade de racionalizar a administração das instituições financeiras. Operam, simultaneamente, carteiras de banco comercial, de investimento, de crédito imobiliário, de crédito, financiamento e investimento, de arrendamento mercantil e de desenvolvimento. Para que se caracterize como múltiplo, o banco deve possuir pelo menos duas das carteiras mencionadas, sendo, obrigatoriamente, uma delas comercial ou a de investimentos. 
- Bancos Cooperativos: em 1995, o BACEN autorizou a constituição de bancos comerciais (fechados), com participação, exclusivamente, de cooperativas de crédito singulares. Dessa forma, as cooperativas de crédito passam a ter seus próprios bancos, utilizando-se das funções comuns de um banco comercial.

- Caixas Econômicas: integram o Sistema Brasileiro de Poupança e Empréstimo e o Sistema Financeiro de Habitação. Têm atividades parecidas com as dos bancos comerciais, podendo captar depósitos à vista e efetuar operações de serviços. Operam crédito direto ao consumidor, financiando bens de consumo duráveis. Uma de suas principais atividades é a centralização do recolhimento e administração dos recursos oriundos do FGTS.

A configuração do SFN, modelada a partir de 1964, sofreu uma grande mudança em sua estrutura a partir da Resolução 1524, de 21/09/1988. Com tal norma, parte-se de instituições especializadas, restritas a uma faixa de operações, para as chamadas instituições "universais". Com a criação dessa modalidade, chamada "Bancos Múltiplos", a legislação permitiu que essas instituições pudessem praticar todos os serviços financeiros.

Segundo o BACEN, em dezembro de 1988, estavam em funcionamento 104 bancos comerciais e 5 caixas econômicas. O quadro inflacionário, desde a década de 60 , foi favorável ao crescimento dos bancos. Essas entidades souberam tirar bom proveito dessa época, acumulando capital, crescendo tecnológica e financeiramente. Após a aprovação da Resolução 1524 de 1988, ocorreu uma grande expansão, fazendo com que o número de bancos mais que dobrasse em dezembro de 1994. Mas a partir de 1995, começa uma reestruturação do sistema bancário brasileiro, conforme explica Arienti (2007, p. 598):

\footnotetext{
A introdução do Plano Real e a conseqüente queda dos índices de inflação levaram os bancos a se adaptarem ao novo ambiente macroeconômico. O ajuste inicial por parte do sistema bancário foi feito através do aumento da oferta de crédito. Contudo, a partir de 1995, com a perspectiva da instauração de uma crise bancária, iniciou-se a reestruturação do setor bancário brasileiro, através da internacionalização, do saneamento do setor e da adesão ao Acordo da Basiléia.
} 
O Gráfico 1 mostra a queda do número de bancos, no período de 1996 a 2007.

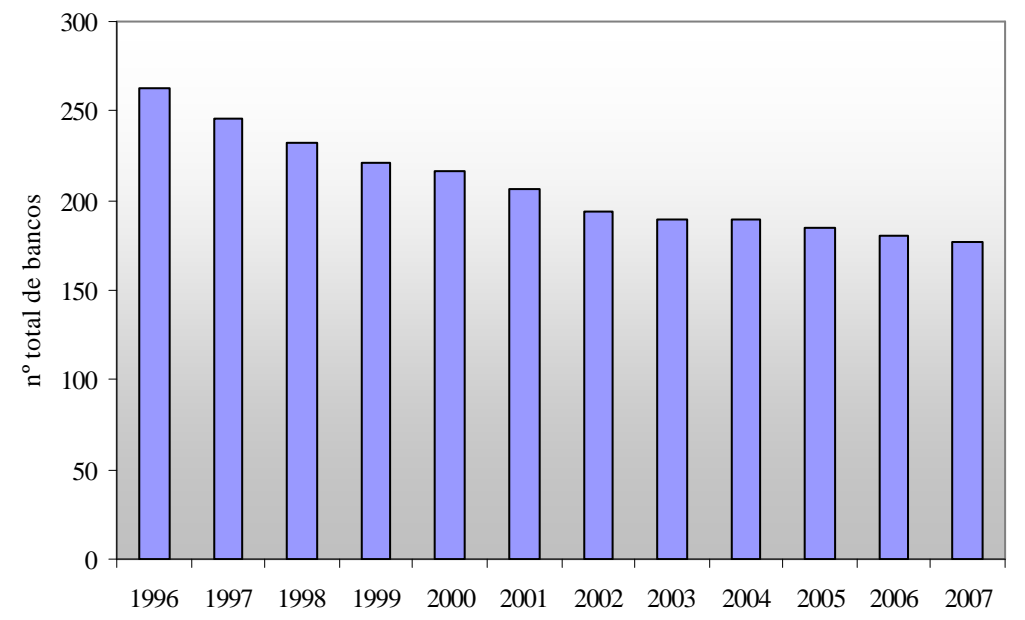

Gráfico 1 - Número de bancos no período de 1996 a 2007 Fonte: Banco Central do Brasil

Essa redução do número de bancos em operação é fruto de uma tendência de consolidação no mundo, conforme argumentam De Paula e Marques (2004, p. 1):

A consolidação bancária - entendida como o processo resultante de uma fusão ou uma aquisição, seja dentro de um setor da indústria financeira ou entre setores, que em geral reduz o número de instituições e aumenta o tamanho destas, assim com o grau de concentração de mercado - é um fenômeno que vem ocorrendo em vários países do mundo.

Os autores mencionam que esse processo de consolidação está ocorrendo com frequência no Brasil, desde 1995, em decorrência da estabilização dos preços, da entrada de bancos estrangeiros no país e da privatização de bancos estaduais.

A globalização da economia, atrelada à redução dos índices inflacionários, passou a exigir o desenvolvimento de novos produtos e grande adaptação à tecnologia, o que revelou a falta de eficiência de alguns bancos. Além disso, novas regras nacionais e internacionais acabaram por liquidar algumas dessas instituições, que não conseguiram se adaptar às novas exigências regulatórias.

Além disso, a partir da criação dos bancos múltiplos em 1988, a estrutura do sistema bancário brasileiro foi alterada significativamente por outros fatores, como menciona Batistella (2005, p. 14), sendo: “[...] redução da participação do estado no setor bancário, principalmente através de processos de privatizações e, também, maior participação dos grupos estrangeiros 
no âmbito do sistema financeiro nacional [...]." Outro fator relacionado à redução do número de bancos é a formação de conglomerados financeiros, com atuação em vários segmentos do mercado, que conforme Assaf Neto (2006, p. 51):

\begin{abstract}
As principais justificativas geralmente apresentadas para essa política de concentração são a de reduzir, via economia de escala, o custo operacional e, conseqüentemente, o custo final do dinheiro, e elevar a eficiência administrativa e produtividade das instituições, capacitando-as a atuar em contextos de maior competitividade.
\end{abstract}

A evolução patrimonial dos bancos é relevante no mercado nacional. Esse item tem se mostrado otimista, partindo do montante de $\mathrm{R} \$ 121,1$ bilhões em 2003, com constante crescimento e atingindo $\mathrm{R} \$ 233,9$ bilhões no ano de 2007. Da mesma forma, cresce o número de empregos gerados pelo setor, apesar de uma breve redução de 2003 para 2004, houve aumentos a partir desse ano, apresentando um total de 431 mil colaboradores em 2007. Como forma de melhorar a prestação de serviços para a sociedade, a rede de atendimento, também, mantém um crescimento constante, com uma variação positiva de aproximadamente $70 \%$ entre 2003 e 2007, atingindo todos os municípios brasileiros. A Tabela 2 apresenta os dados com base no Relatório Anual de 2007 da FEBRABAN, demonstrando o crescimento do setor.

Tabela 2 - Evolução do setor bancário

\begin{tabular}{l|r|r|r|r|r}
\multicolumn{1}{c|}{ Item } & \multicolumn{1}{c|}{$\mathbf{2 0 0 3}$} & \multicolumn{1}{c|}{$\mathbf{2 0 0 4}$} & \multicolumn{1}{c|}{$\mathbf{2 0 0 5}$} & \multicolumn{1}{c|}{$\mathbf{2 0 0 6}$} & \multicolumn{1}{c}{$\mathbf{2 0 0 7}$} \\
\hline Patrimônio Líquido (R\$ bi) & 121,1 & 137,6 & 153,2 & 186,2 & 233,9 \\
\hline Total de Colaboradores (mil) & 389,1 & 382,0 & 403,0 & 425,0 & 431,0 \\
\hline Rede de atendimento & 87.715 & 98.727 & 123.993 & 134.114 & 147.857 \\
\hline
\end{tabular}

Fonte: Relatório Anual 2007 - FEBRABAN

O Gráfico 2, a seguir, demonstra o percentual de participação de cada setor, na distribuição do valor adicionado dos bancos. O primeiro setor é o de Recursos Humanos, que engloba salários e honorários, encargos sociais, benefícios e participações. Esse setor saltou de uma participação no valor adicionado dos bancos de $\mathrm{R} \$ 33,3$ bilhões em 2004, para $\mathrm{R} \$ 45,5$ bilhões em 2007. O segundo é o Governo, contemplando despesas tributárias, imposto de renda e contribuição social, e contribuição do INSS sobre salário, que de uma média de R $\$ 20$ bilhões em 2004, passou para R \$33,2 bilhões em 2007. Por fim, o terceiro setor é o que foi distribuído Líquido para Acionistas, somando os dividendos distribuídos, os lucros retidos e os prejuízos. Esse último setor teve um aumento significativo, passando de $\mathrm{R} \$ 23,3$ bilhões em 2004 para R \$ 58,2 bilhões em 2007: um crescimento maior que $100 \%$. 


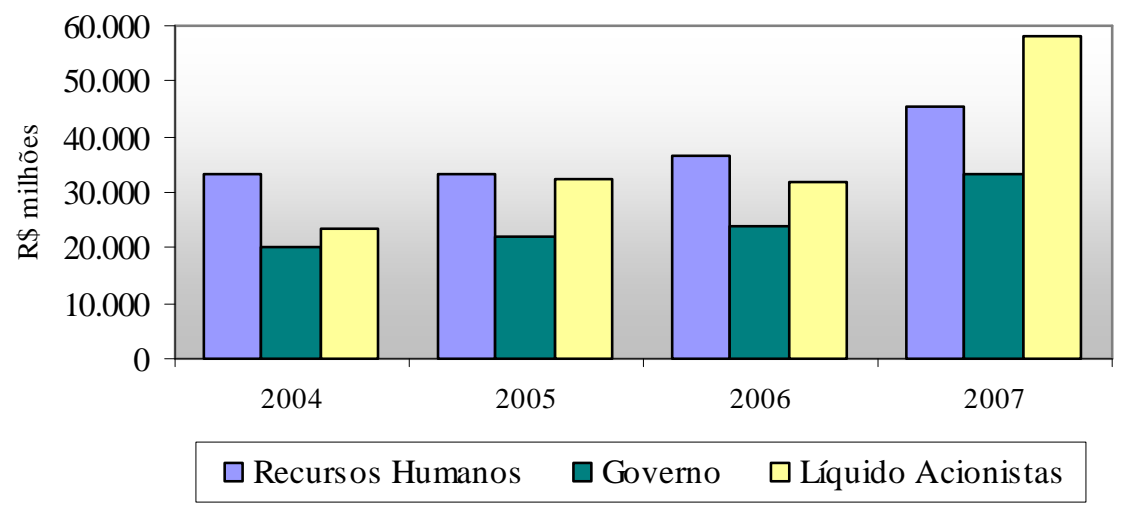

Gráfico 2 - Distribuição de valor adicionado dos bancos Fonte: Relatório Anual 2007 - FEBRABAN

\subsection{Performance e eficiência do setor bancário}

Nos últimos anos, o setor bancário vem apresentando um alto nível de rentabilidade. A sociedade brasileira está acostumada a observar os altos índices de lucratividade do setor, juntamente com o crescimento dessas instituições. Os bancos, com sua criação constante de novos produtos e operações, conseguem se adaptar e se manter com um crescimento elevado em ambientes de turbulências econômicas como é o caso do mercado brasileiro. $\mathrm{O}$ último relatório divulgado pela FEBRABAN, no primeiro semestre de 2008, demonstra que, no ano de 2007 , houve um crescimento de 9,3\%, em relação ao ano anterior, no número de contas correntes que totalizaram 112,1 milhões. A rentabilidade média do PL dos 50 maiores bancos (segundo Revista Exame de Julho/2008) ficou na casa dos 16\% no ano de 2007.

A performance de um banco está relacionada com a sua capacidade de gerenciar os riscos, gerando valor a partir de recursos de terceiros. Para Carvalho (1993, p. 4), "Similar aos negócios não-financeiros, um banco obtém fundos dos investidores e dos proprietários, gasta fundos com matéria-prima, mão-de-obra e capital, e espera recuperar fundos que excedam os valores despendidos." O autor, ainda, defende que “[...] o objetivo básico de um banco deverá ser maximizar o valor do investimento de seus proprietários." 
Para Brandão et al. (2005, p. 3):

\begin{abstract}
A performance das empresas no setor bancário pode depender de várias questões: fatores econômicos que levam todo o setor a uma maior rentabilidade, fatores legais, políticos, que também poderiam influenciar todo o setor, influência das estratégias escolhidas, e ainda estratégias de marketing que estruturam as relações da empresa com o mercado e passam imagem e informações para o mesmo.
\end{abstract}

Dessa forma, diversos fatores podem estar relacionados ao aumento de receitas de produtos e prestação de serviços dos bancos, não só, apenas, sua capacidade interna de gerenciamento de custos.

Alguns bancos adotam como estratégia na tentativa de obter maior performance, a expansão num determinado setor financeiro, por exemplo. O trabalho de Hirtle e Stiroh (2006, p. 1101) aponta que "Os bancos norte-americanos, particularmente os maiores, estão expandindo drasticamente suas operações de banco de varejo nos últimos anos." Para os autores, esse foco em varejo pode ser visto pela contínua expansão dos setores bancários e as recentes motivações de grandes fusões. Os resultados desse trabalho sugerem que o setor de varejo para bancos apresenta um baixo retorno para a amostra selecionada, porém essas operações de varejo são capazes de reduzir o risco das grandes instituições, já que essas estavam acostumadas com outras operações de grandes riscos.

Para Tabak et al. (2005, p. 2), “A indústria bancária, quando comparada às demais indústrias, apresenta características peculiares que a distinguem na avaliação de performance, eficiência e resultados, bem como são mais específicos a regulamentação e os registros contábeis." Para os autores, acompanhar a performance dos bancos é uma constante preocupação "[...] não apenas para depositantes, mas também para investidores, analistas de mercado, pesquisadores, gestores administrativos, órgãos reguladores e instituições governamentais [...].”

A performance de uma instituição financeira pode estar, também, diretamente relacionada à estrutura de cargos dos executivos. O trabalho de PI e Timme (1993, p. 528) examinou a relação entre performance e a estrutura de administradores de uma amostra de bancos norteamericanos. Os autores concluíram que as instituições em que os CEOs eram, também, o presidente do conselho tinham menos performance do que aquelas que não tinham essa estrutura. 
Para a avaliação da performance ou eficiência de uma instituição, as pesquisas podem ser realizadas por análises de índices. Conforme Matarazzo (2003, p. 148), "Os índices servem de medida dos diversos aspectos econômicos e financeiros das empresas." O autor salienta, igualmente, que "O importante não é o cálculo de grande número de índices, mas de um conjunto de índices que permita conhecer a situação da empresa, segundo o grau de profundidade desejada da análise.” Dessa forma, diversos indicadores podem mensurar a performance de uma instituição. Não se pode restringir mensuração de performance apenas por índices baseados nos resultados contábeis, tal como Retorno sobre o Patrimônio (ROE) ou Retorno sobre o Ativo (ROA). Para os bancos, algumas de suas operações podem não aparecer nas demonstrações contábeis, mas tais operações têm o poder de influenciar fortemente em sua performance.

Um dos indicadores utilizados para medir a eficiência de uma instituição financeira é o Índice de Eficiência Operacional. Segundo Assaf Neto (2007, p. 321), “Quanto menor se apresentar o índice, mais elevada se apresenta a produtividade, ou seja, o banco demonstra a necessidade de uma menor estrutura operacional para manter suas atividades." Tal índice é calculado da seguinte forma:

$$
\text { IE Operacional }=\frac{\text { Despesas Operacionais }}{\text { Receitas de Intermediação Financeira }}
$$

O trabalho de Neves Jr. et al. (2007) aborda o Índice de Eficiência Operacional para instituições financeiras. Os autores analisaram o resultado desse índice nos 50 maiores bancos brasileiros, de acordo com a classificação do ranking BACEN, utilizando uma base histórica de 2001 a 2005. Ao aplicar métodos estatísticos, a pesquisa concluiu que "[...] aparentemente o grau de explicação da Eficiência Operacional pode ser determinado por fatores externos como a conjuntura econômica [...]." Apesar de o trabalho apresentar um índice calculado por dados financeiros das instituições, o resultado encontrado deixa certa subjetividade para conclusões, pois com as variáveis financeiras dos bancos, utilizadas para calcular o índice, não foi possível fazer um relacionamento com a eficiência operacional.

Além de medir a performance, alguns índices são de extrema importância, pois fornecem algumas informações sobre a posição financeira da entidade. Um índice destacado por Gitman (2004, p. 46) é o Índice de Liquidez Corrente. O autor explica que "A liquidez de uma 
empresa é medida por sua capacidade de cumprir as obrigações e curto prazo à medida que vencem. Corresponde à solvência da posição financeira geral da empresa - a facilidade com que pode pagar suas contas.” Dessa forma, esse Índice de Liquidez Corrente é utilizado para analisar a capacidade da empresa de saldar suas obrigações de curto prazo. Em instituições financeiras, essa capacidade torna-se uma obrigação, regulamentada e com índices predeterminados pelo Banco Central do Brasil.

$$
\text { Índice de Liquidez Corrente }=\frac{\text { Ativo Circulante }}{\text { Passivo Circulante }}
$$

Outros índices apresentado por Gitman (2004, p. 56) são os índices de valor de mercado. O autor menciona que "Os índices de valor de mercado relacionam o valor de mercado da empresa, medido pelo preço corrente da ação, a certos valores contábeis.” Dessa forma, é possível entender o quanto a instituição representa para os investidores. Esses índices " [...] tendem a refletir, em termos relativos, a avaliação de todos os aspectos do desempenho passado e do esperado para o futuro pelos acionistas."

Gitman (2004) destaca dois índices de valor de mercado que são muito utilizados. O primeiro é o índice preço/lucro, mostrando quanto o investidor está disposto a pagar por unidade de lucro da empresa. É muito utilizado para indicar a apreciação dos proprietários sobre o valor da ação. Sendo assim, esse índice pode refletir o grau de confiança que os investidores têm sobre o futuro desempenho da organização.

$$
\text { Índice } \mathrm{P} / \mathrm{L}=\frac{\text { Preço por Ação }}{\text { Lucro por Ação }}
$$

O segundo índice é preço/valor patrimonial, que expressa o valor de mercado da empresa em termos de seu patrimônio líquido. É calculado como valor de mercado (Preço) dividido pelo valor patrimonial por ação da empresa.

$$
\text { Índice P/VPA }=\frac{\text { Preço }}{\text { Valor Patrimonial por Ação }}
$$


Tendo em vista o grande poder de influência das variáveis externas à instituição, Ferreira e Farina (2005) realizaram um trabalho que discute como as características básicas do mercado podem influir na estrutura do setor e, consequentemente, na forma de atuação das instituições que dele participam. Para os autores, regiões com um grande grupo de clientes possuem um grande número de instituições, com isso, uma competição intensa, pagando taxas mais baixas. Em regiões com demandas menores, os bancos não se instalam, pois os possíveis lucros não são suficientes para cobrir os custos de instalação. O trabalho mostra que os bancos analisam um fator externo (tamanho do mercado) para se instalar e competir com seus concorrentes. Os autores finalizam com "As conclusões deste trabalho enfatizam que a redução dos spreads e o aumento do volume de crédito concedido pelo setor bancário passam pelo acesso a informações fidedignas sobre os potenciais clientes."

Outra forma de analisar desempenho, alternativa às análises de índices contábil-financeiros é mediante a utilização de técnicas não paramétricas. O trabalho de Macedo et al. (2005) utiliza a técnica conhecida como Análise Envoltória de Dados (DEA). Essa pesquisa busca um índice de performance relativa que seja capaz de conjugar indicadores financeiros de liquidez, de custo, de risco e de rentabilidade na análise de desempenho organizacional. Segundo os autores, "Os resultados desse estudo propõem uma nova percepção sobre a performance financeira de bancos que não se encontram disponíveis aos gestores e ao mercado em geral através dos balanços e tradicionais análises de índices financeiros.” Ainda, enfatizam que:

[...] a partir de informações que não estariam disponíveis pelas técnicas convencionais, os resultados da análise envoltória de dados podem proporcionar melhores condições de competitividade aos bancos, principalmente quando interpretadas e usadas com os conhecimentos e julgamentos próprios da alta administração sobre as operações de seus bancos.

A próxima seção faz uma breve apresentação sobre os riscos nas instituições financeiras, que são os principais fatores para os resultados de performance nessas entidades.

\subsection{Riscos nas instituições financeiras}

Damodaran (1999, p. 35), ao tratar sobre riscos em sua obra, começa afirmando que "Risco, em termos tradicionais, é visto como algo negativo." Para o autor, risco é uma mistura entre perigo e oportunidade. Numa visão financeira, o autor define o risco como a distribuição de 
retornos atuais sobre os retornos esperados e, um teste-chave em finanças, é "“[...] assegurar que quando um investidor está exposto ao risco, este será apropriadamente remunerado por assumir tal risco."

Capelletto e Corrar (2008, p. 7) apresentam um conceito que vai além de perigo ou chance, ao afirmarem que "O risco é uma variável determinante da evolução humana, pois a sua ausência implica a certeza de resultados e restrição à construção de conhecimentos." Os autores complementam o conceito de risco, mencionando que "a concepção atual de risco tem origem nos números que permitem quantificar o valor incerto, antes abstrato, produzido por determinada ação."

Perigo ou chance não constituem um sentido restrito para risco. Para Ross et al. (2000, p. 295), “A parte não antecipada do retorno, ou seja, a que resulta de surpresas, é o verdadeiro risco de um investimento.” Jorion (1998, p. 3) define o risco ligado ao resultado inesperado, ao afirmar que "risco pode ser definido como a volatilidade de resultados inesperados, geralmente associada ao valor de ativos ou passivos de interesse."

Corroborando os autores acima, Gitman (2004, p. 184) afirma que o risco é a possibilidade de que os resultados realizados possam ser diferentes dos esperados. Para o autor, "[...] a palavra risco é usada como sinônimo de incerteza e refere-se à variabilidade dos retornos associados a um ativo."

Trapp (2004, p. 25) deduz que “[...] o risco das empresas pode ser definido como um evento, esperado ou não, eu pode causar impacto no capital ou ganhos de uma instituição.” Dessa forma, justifica-se a grande dificuldade de uma entidade em mensurar riscos, pois esse pode partir de um evento não esperado, ocasionado por fatores advindos de um ambiente externo e fora de controle da empresa.

Nessa mesma linha, Goulart (2003, p. 74) menciona que "O risco existe quando há probabilidade de experimentar retornos diferentes do que se espera." Todavia, o autor destaca que "[...] as definições tendem a enfocar as chances de resultados negativos, ou seja, aqueles que podem representar prejuízo ou serem inferiores ao esperado." Assim, mensurar o risco pode ter o significado de encontrar a probabilidade de ter um resultado negativo no retorno de um investimento. 
O que todos procuram é aumentar o retorno e evitar ao máximo os riscos existentes. Para Brealey et al. (2008, p. 722), "Para adicionar valor, as empresas devem assumir riscos. Mas elas tentam evitar esses riscos, que não carregam nenhum ganho compensatório." Os autores mencionam que as empresas estão expostas a uma lista de incertezas, tal como mudanças no fluxo de caixa, mudanças nos custos de matéria-prima, tecnologia e uma infinidade de outras incertezas que acarretam riscos.

A definição de riscos, encontrada na literatura, é válida para qualquer tipo de entidade, porém, com diferentes características. Os bancos diferenciam-se de outras entidades, por suas características peculiares e operações que envolvem grandes riscos. Segundo Carvalho (1993, p. 11):

\footnotetext{
As proporções entre ativos e passivos em bancos são freqüentemente diferentes se comparadas com negócios não financeiros, uma vez que bancos tendem a ter importâncias limitadas em ativos fixos (como edifícios) e capital dos acionistas, sendo os ativos e passivos extremamente elevados a curto prazo $[\ldots]$
}

Nas operações atuais, com o envolvimento dos mais diversos tipos de instrumentos financeiros, novos tipos de riscos surgiram devido à grande variabilidade de operações realizadas e à enorme volatilidade dessas operações. Bollerslev et al. (1992, p.62) afirmam que a "volatilidade é uma variável-chave que permeia a maioria dos instrumentos financeiros e que exerce um papel central em diversas áreas de finanças.” Desse modo, já é de se esperar uma maior atenção aos riscos por parte das instituições financeiras.

Devido à grande complexidade das operações realizadas, atualmente, pelos bancos, essas entidades gastam uma grande atenção e investimento financeiro aos riscos envolvidos nos processos. Áreas são criadas dentro das instituições com a finalidade de controle e monitoramento dos riscos. Além da evolução nas operações, outros fatores contribuíram para uma atenção especial aos riscos bancários. Entre esses fatores, destacam-se as fraudes e falhas ocorridas a partir da década de 90 no mundo todo.

\subsubsection{Tipos de riscos}

$\mathrm{Na}$ seção anterior, diversos estudos foram revisados na tentativa de apresentar uma definição para risco. Existem algumas divergências nas definições e, conforme Damodaran (1999, p. 
40), “[...] essas divergências podem ser causadas por inúmeras razões, e essas razões podem ser classificadas em duas categorias [...].” Dessa maneira, Damodaran (1999), corroborado por Ross et al. (2000, p. 296), dividem os riscos em duas grandes categorias:

I. Risco Sistemático: também conhecido como risco de mercado, é aquele que afeta um grande número de ativos. Gitman (2004, p. 200) classifica o risco sistemático como risco não diversificável. Para o autor, esse risco "[...] é atribuível a fatores de mercado que afetam todas as empresas e não pode ser eliminado por meio de diversificação.” Alguns exemplos dados são: "Guerra, inflação, incidentes internacionais e eventos políticos."

II. Risco Não Sistemático: também conhecido como risco específico, afeta apenas um único ou um pequeno grupo de ativos. Classificado por Gitman (2004, p. 200) como risco diversificável e que:

[...] apresenta a parte do risco de um ativo associado a causas aleatórias e que pode ser eliminada com a diversificação da carteira. É atribuível a eventos relacionados especificamente à empresa, tais como greve, ações judiciais, decisões de agências reguladoras e perda de um cliente importante.

Saunders (2000, p. 99-109) não segue uma divisão em grandes grupos, mas, sim, um detalhamento dos tipos básicos de riscos enfrentados pelas instituições financeiras. Abaixo são apresentados, resumidamente, os riscos elencados pelo autor.

\section{A. Risco da variação de taxa de juros}

Os bancos atuam com uma maior sensibilidade às taxas de juros que as demais empresas de outros segmentos. Os seus ativos e passivos estão muito atrelados à qualidade e maturidade dos empréstimos e fundos captados, respectivamente. Os riscos da variação da taxa de juros para uma instituição financeira pode estar em simples operações, como a de adquirir títulos primários com características de prazos e liquidez distintas das apresentadas pelos títulos secundários que são vendidos. Esse descasamento expõe a entidade ao risco de variação de taxa de juros. 


\section{B. Risco de mercado}

O risco de mercado compreende a possibilidade de perda financeira devido a movimento nos preços de mercado e, até mesmo, nas oscilações de taxas de juros, afetando as posições de ativos e passivos mantidos pelas instituições. Brito (2000, p. 69) afirma que "O risco de mercado pode representar perda econômica diante das flutuações desfavoráveis das variáveis dos ativos relacionados, as quais estão presentes, particularmente, em mercados de juros, ações, câmbio e índices." Numa instituição financeira esse risco existe, por exemplo, quando essa negocia ativos e passivos (e derivativos), assumindo uma posição a descoberto, comprada ou vendida, e os preços variam em direção oposta à esperada. A grande volatilidade de ativos pode aumentar os fatores para esse risco. Dessa forma, a instituição precisa de controles que limitem as posições das operações.

\section{Risco de crédito}

Esse risco pode existir quando há uma baixa qualidade do tomador de crédito e esse pode não honrar o pagamento de títulos devidos, comprometendo o fluxo de caixa da instituição. Desse modo, os bancos precisam, constantemente, monitorar e se informar sobre a carteira de crédito em seus ativos. Brito (2000, p. 68) caracteriza esse tipo de risco "[...] pela perda da totalidade do principal acrescido dos juros contratuais. O risco de não recebimento dá-se pelo não cumprimento da obrigação de pagar, por parte do devedor." $\mathrm{O}$ autor, ainda, afirma que "Na atividade bancária, este tipo de risco apresenta-se de forma intensa, uma vez que, nas transações bancárias, o direito de receber sempre é de uma das partes." Assim, o risco sempre passa pela instituição financeira, que está intermediando as operações.

\section{Risco de operações fora do balanço}

Esse tipo de risco está relacionado às operações que não são registradas em balanço, tais como: avais, garantias, cartas-fiança, contratos futuros, operações com opções ou swaps, entre outras. Uma atividade fora do balanço existe quando ocorre uma operação, mas que a instituição não tem a posse de um direito ou a emissão de uma obrigação. Dessa forma, essas atividades fora de balanço podem afetar a forma futura do balanço, pois criam ativos e passivos condicionais a eventos que irão ocorrer. Bennett (1986, p. 19) apresenta alguns exemplos de operações fora do balanço e afirma que "Apesar deles não aparecerem reconhecidos como ativo ou passivo no balanço do banco, essas contingências exigem o envolvimento de taxas de juros, créditos e riscos de liquidação." Dessa maneira, essas operações apresentam um grande potencial de riscos para os bancos. 


\section{E. Risco tecnológico e operacional}

Os bancos realizam pesados investimentos em tecnologia, porém há um risco tecnológico quando esses investimentos não refletem nas reduções esperadas de custos, em termos de economia de escala ou escopo. Um ambiente amplo e muitas vezes inseguro, como a Internet, pode deixar o banco vulnerável, principalmente com relação às informações dos clientes. Já o risco operacional, relaciona-se com uma falha dos sistemas existentes, quando esses deixam de funcionar adequadamente.

\section{F. Risco de câmbio}

Os bancos procuram expandir-se, com uma intensificação da globalização de suas operações, porém operações com moedas estrangeiras podem expor a instituição ao risco de câmbio, pois pode ocorrer uma liquidação à taxa de câmbio diferente da esperada quando se assumiu a posição. Glaum (1990, p. 66) define Risco de Câmbio como “[...] a probabilidade de mudanças, para melhor ou pior, no valor da moeda funcional de um ativo, passivo ou no curso de um fluxo de caixa, causado por uma mudança não esperada na taxa de câmbio futura."

Cornell e Shapiro (1983) apresentam dois componentes para a exposição ao risco de câmbio. O primeiro é a exposição transacional, sendo a possibilidade de incorrer em ganhos ou perdas cambiais numa data futura, em transações já realizadas em moeda estrangeira. O segundo é a exposição operacional, que é resultado das flutuações do valor da moeda em conjunto com os ajustamentos de preços, afetando o fluxo de caixa da entidade. Dessa forma, Merlotto, Pimenta Júnior e Rosifini Júnior (2008, p. 3) concluem que "[...] o risco de exposição ao câmbio não depende somente do montante das transações internacionais que uma companhia realiza, mas também do grau de exposição a influências externas a que as economias dos países em que atua estão sujeitas."

\section{G. Risco soberano}

Semelhante ao risco de crédito, porém mais sério, ocorre quando estrangeiros podem deixar de honrar seus pagamentos ao banco. Esse risco é externo à instituição financeira, sendo relacionado ao risco-país, com sua capacidade de pagamento dos compromissos externos. Um dos fatores mais comuns que contribui para que isso aconteça é quando o governo do país proíbe o pagamento (ou impõe limites), por motivos de insuficiência de reservas ou motivos políticos. 


\section{H. Risco de liquidez}

Esse risco existe quando os titulares dos passivos da instituição exigem dinheiro imediato da instituição e essa não possui recursos financeiros suficientes para honrar esse compromisso. $\mathrm{O}$ que ocorre é um descasamento entre o ativo e o passivo da instituição financeira. Como, por exemplo, se todos os titulares de poupança de um banco exigirem a retirada do dinheiro. Dessa forma, a entidade fica forçada a obter recursos adicionais ou a liquidar ativos para atender às exigências de retirada de fundos. Corroborando essa afirmação, Capelletto e Corrar (2008, p. 9) informam que "A falta de liquidez obriga a rápida realização de ativos e provoca a queda nos preços, desvalorizando ativos iguais ou semelhantes detidos por outras instituições." Tal ação pode ocasionar uma "corrida bancária”, o que apresenta grandes preocupações para as autoridades monetárias do país.

\section{Risco de insolvência}

O Risco de Insolvência resume-se à insuficiência de recursos próprios ou internos de uma instituição financeira para cobrir perdas incorridas em função de um ou mais riscos de alguma natureza descrita anteriormente. Desse modo, quanto maior o Risco de Insolvência de uma instituição, menor suas chances de conseguir sobreviver a um dos riscos anteriormente mencionados.

Para Trapp (2004, p. 31), além dos riscos elencados por Saunders (2000, p. 99-109), existem outros tipos de riscos que podem afetar uma instituição financeira. A autora menciona: o risco legal, o risco de reputação ou imagem, o risco sistêmico, o risco humano, o risco de liquidação e, finalmente, o risco operacional.

O risco legal é de grande relevância para os bancos que operam no Brasil. De acordo com Santos (2007, p. 15), “[...] as instituições financeiras brasileiras sofrem impactos significativos derivados do ambiente legal." O autor explica que "[...] grande parte do risco legal já é apresentada na forma de provisões para devedores duvidosos. Neste último caso o que se vê é um outro efeito do nosso sistema legal, que é criar, em alguns casos, um ambiente favorável à inadimplência." Assim, o sistema legal em que os bancos estão inseridos no Brasil, influencia não só os aspectos relacionados à provisão, mas, também, o desenvolvimento do crédito bancário. Para Santos (2007, p. 23), “[...] a tarefa de definir risco legal é complexa. Isto decorre do fato do risco legal ser inerente a praticamente qualquer operação de uma instituição financeira." 
Os riscos de reputação ou imagem são aqueles que podem afetar, negativamente, a imagem da instituição perante seus clientes, o que pode acarretar prejuízos nos negócios. Pode-se ter esse risco, quando problemas de outros riscos já ocorreram, por exemplo, problemas operacionais. Já os riscos sistêmicos decorrem de problemas externos à entidade, que podem afetar todo o sistema no qual ela está inserida, transmitindo dificuldade para todos. Para Capelletto e Corrar (2008, p. 7), “[...] o crescente número de operações financeiras e a maior interdependência dos mercados fizeram com que o sistema financeiro internacional assumisse a função de principal propagador de riscos.” Para os autores, “[...] todos os países participantes do sistema se tornaram suscetíveis às fragilidades verificadas em outros países." Para Chen (1999), uma forma de conter esses problemas, no sistema bancário, seria a imposição de uma disciplina no mercado, com depositários ou outros credores dos bancos compartilhando a responsabilidade do monitoramento do setor bancário.

O risco humano é difícil de ser mensurado, pois está relacionado à tomada de decisões humana nos processos, sendo totalmente subjetivo. Esse risco, conforme Trapp (2004, p. 32), envolve, também, “[...] recrutamento, treinamento, motivação e retenção de pessoal.” O Risco de Liquidação citado por Trapp (2004, p. 31) é o próprio Risco de Liquidez já mencionado e explicado por Saunders (2000, p. 99-109), ou seja, quando ocorrem problemas no sistema de pagamentos.

Outro risco de grande importância para estudos em bancos é o risco operacional. Lima e Lopes (1999, p. 104) relacionam o risco operacional com deficiências tecnológicas, ao afirmarem que "[...] os riscos operacionais estão relacionados à capacidade dos sistemas de uma organização de processarem as informações de forma precisa e dentro de um horizonte de tempo adequado." Já a definição dada pelo Banco Central, pela Resolução n. 3.380, vai além dessas deficiências, apresentando uma lista de eventos que possam levar ao risco operacional, conforme:

\footnotetext{
$\S 2$ - Entre os eventos de risco operacional, incluem-se:

I - fraudes internas;

II - fraudes externas;

III - demandas trabalhistas e segurança deficiente do local de trabalho

IV - práticas inadequadas relativas a clientes, produtos e serviços

$\mathrm{V}$ - danos a ativos físicos próprios ou em uso pela instituição

VI - aqueles que acarretem a interrupção das atividades da instituição;

VII - falhas em sistemas de tecnologia da informação;

VIII - falhas na execução, cumprimento de prazos e gerenciamento das atividades na instituição.
} 
Conforme Trapp (2004, p. 106), "Os riscos operacionais ainda são pouco analisados, acompanhados e controlados pelas instituições financeiras, mesmo internacionalmente, estando em seus primórdios no que tange à identificação, à avaliação, ao registro e ao controle [...]." Dessa maneira, os riscos operacionais passam a ter uma importância, gradativamente, maior, principalmente, por causa de descoberta de fraudes, falências e outros problemas em bancos, ocasionados por falta de controles e práticas irregulares.

\subsubsection{Gestão de riscos em bancos}

A importância da gestão dos riscos em bancos teve um grande crescimento nos últimos anos. Segundo Goulart (2003, p. 9), “[...] órgãos internacionais e bancos centrais de diversas nações têm publicado documentos que tratam do tema, abordando as características que devem possuir os sistemas de gestão de risco das instituições financeiras [...].” O autor, também, destaca a importância que esses órgãos dão à divulgação de informações financeiras das instituições, periodicamente.

Para Brito (2000, p. 23), “A gestão do risco é o processo por meio do qual as diversas exposições ao risco são identificadas, mensuradas e controladas." O autor defende, ainda, que tal gestão “[...] é fundamental para que a instituição financeira compreenda os riscos assumidos, dimensionando-os e adequando-os aos seus objetivos relacionados ao riscoretorno."

Os bancos precisam ter uma estrutura que seja capaz de satisfazer seus credores, com uma remuneração sustentável e satisfatória e, ao mesmo tempo, que atenda seus objetivos de lucros. Brito (2000, p. 50) destaca que “[...] no ambiente em que as instituições financeiras interagem, os riscos apresentam diversas formas e variadas características. Todos os players buscam conjugar a maximização do retorno com a minimização do risco.” Assim, a gestão dos riscos é fundamental na obtenção dos retornos desejados.

Trapp (2004, p. 106) enfatiza que:

As instituições financeiras têm se especializado na gestão dos seus riscos, tanto porque atuam em um ambiente instável com variáveis que apresentam grande volatilidade, ou porque, conseqüentemente, os órgãos reguladores estão impondo padrões mínimos de identificação, medição e controle. 
Sendo assim, não são apenas as necessidades internas para alcançar lucros e boas rentabilidades que incentivam as instituições a terem uma adequada gestão de riscos, mas, também, os órgãos reguladores do setor.

As novas operações realizadas pelas instituições financeiras podem trazer novos tipos de riscos, mas algumas servem para sua mitigação que existiam anteriormente. Dessa forma, Brito (2000, p. 50) explica que "Muitos riscos de difícil identificação e mensuração que faziam parte das transações antes desta década passaram a ser conhecidos e neutralizados por meio de estruturas de Hedging, evitando grandes perdas aos agentes." O autor exemplifica essas operações com os instrumentos derivativos, muito utilizados a partir da década de 90 para a proteção de riscos de mercado.

Com a evidente quantidade de riscos que envolvem as instituições financeiras, tornou-se necessário o desenvolvimento de uma padronização global para o controle dos riscos dessas instituições, com a finalidade de fortalecer o sistema financeiro internacional. Por isso, surge, em 1988, o primeiro acordo com a finalidade de minimizar os riscos de insolvência dos bancos no mundo todo, conhecido por "Acordo de Basileia".

\subsubsection{Acordo da Basileia I}

Em dezembro de 1974, criou-se o Comitê de Supervisão Bancária da Basileia, com o objetivo de promover boas práticas bancárias, espalhando-as pelo mundo todo. Esse comitê está subordinado ao Bank for International Settlements (BIS), sediado na Suíça. Em 1988, a fim de minimizar os riscos de liquidez e insolvência dos bancos no mundo, o Comitê aprovou um acordo sobre exigências de capital mínimo dos bancos, que ficou conhecido como "Acordo da Basileia”. Para Andrezo e Lima (2007, p. 206), "Esse acordo tinha como objetivo padronizar as normas sobre solidez dos bancos, de modo a minimizar os riscos de insucesso bancário e permitir análise comparativa entre os bancos no plano internacional."

No Brasil, a adoção do Acordo de Basileia foi feita por meio da Resolução CMN n. 2.099/94, que trata da metodologia sobre níveis mínimos de capital previstos no Acordo. Antes dessa Resolução, Andrezo e Lima (2007, p. 207) mencionam que “As regras brasileiras até então existentes não faziam qualquer diferenciação quanto aos níveis de risco dos bancos." Para os 
autores, a Resolução "[...] passou a exigir a compatibilização do capital com o grau de risco dos ativos da instituição financeira."

Dessa forma, a Resolução CMN n. 2.099 de 1994 deu início, no Brasil, a uma regulamentação com o objetivo de proteger o sistema financeiro e seus investidores, estando alinhada ao Acordo de Basileia. Com isso, os bancos, operando no Brasil, passam a ter uma maior solidez e aceitação de investidores internacionais. A Resolução é formada por quatro anexos, discutidos a seguir, que tratam das regras para funcionamento e manutenção das instituições financeiras.

O primeiro anexo trata da autorização para funcionamento, transferência de controle societário e reorganização. As regras desse anexo foram revogadas pela Resolução CMN n. 3.040/02, que prevê que a constituição está submetida à demonstração de capacidade econômico-financeira compatível com o porte, natureza e objetivo do empreendimento. $\mathrm{O}$ anexo II aborda os limites mínimos de capital realizado e patrimônio líquido, sendo que esses limites variam de acordo com o tipo e modalidade operacional das instituições. O terceiro anexo trata da instalação e do funcionamento de dependências no país, regulamentando os tipos de dependências, como, por exemplo, os postos de atendimentos, autorizados a funcionar para as instituições.

O quarto e último anexo é a essência do Acordo de Basileia, tratando do Patrimônio Compatível com o Grau de Risco dos Ativos. De acordo com a Resolução CMN n. 3.040/02, a metodologia, originalmente, apresentada para cálculo era a seguinte:

Art. 2o $\mathrm{O}$ cálculo do valor de patrimônio líquido referido no artigo anterior obedecerá à seguinte fórmula:

PLE $=0,08$ (APR), onde:

PLE = patrimônio líquido exigido em função do risco das operações ativas;

APR = Ativo ponderado pelo risco = total do produto dos títulos do Ativo Circulante e Realizável a Longo Prazo (código 1.0.0.00.00-7 do COSIF) pelos fatores de risco correspondentes + produto do Ativo Permanente (código 2.0.0.00.00-4 do COSIF) pelo fator de risco correspondente + produto dos títulos de Co-obrigações e Riscos em Garantias Prestadas (código 3.0.1.00.00-4 do COSIF) pelos fatores de risco correspondentes.

Verrone (2007, p. 33) sintetiza que:

Basiléia I estabeleceu que o capital mínimo necessário para cobrir os riscos e preservar a capacidade de pagamento das instituições financeiras deveria corresponder a $8 \%$ (oito porcento) da 
soma de seus ativos. Cada ativo, no entanto, seria computado em função de um peso variável de acordo com seu respectivo risco, compondo assim o APR - Ativo Ponderado Pelo Risco.

Andrezo e Lima (2007, p. 211) mencionam que "A ponderação dos ativos é feita com base nos fatores de riscos das operações, classificados de acordo com uma tabela." A Tabela 3, a seguir, apresenta exemplos dos fatores de riscos para cálculo do ativo ponderado.

Tabela 3 - Exemplo de fatores de risco

\begin{tabular}{|c|c|}
\hline Ativo & $\begin{array}{l}\text { Fator de Risco para cálculo } \\
\text { do ativo ponderado } \\
\end{array}$ \\
\hline $\begin{array}{l}\text { Reserva bancária, caixa, operações ativas de responsabilidade ou com } \\
\text { garantia do Tesouro Nacional e depósitos no BACEN }\end{array}$ & $\begin{array}{l}0 \% \\
\text { (risco nulo) }\end{array}$ \\
\hline $\begin{array}{l}\text { Depósitos bancários, aplicações em ouro e cheques enviados à } \\
\text { compensação }\end{array}$ & $\begin{array}{l}20 \% \\
\text { (risco reduzido) }\end{array}$ \\
\hline $\begin{array}{l}\text { Operações ativas de responsabilidade ou com garantia de outras } \\
\text { instituições financeiras (exemplo: aplicações em CDI) e aplicações em } \\
\text { moedas estrangeiras no exterior }\end{array}$ & $\begin{array}{l}50 \% \\
\text { (risco reduzido) }\end{array}$ \\
\hline $\begin{array}{l}\text { Empréstimos e financiamentos, operações de arrendamento e de câmbio, } \\
\text { aplicações em ações e ativo permanente }\end{array}$ & $\begin{array}{l}100 \% \\
\text { (risco normal) }\end{array}$ \\
\hline $\begin{array}{l}\text { Créditos Tributários decorrentes de imposto de renda e contribuição } \\
\text { social }\end{array}$ & $300 \%$ \\
\hline
\end{tabular}

Fonte: Adaptado de Andrezo e Lima (2007, p. 212)

O trabalho desenvolvido por Casella e Bispo (2007) procurou verificar o impacto do Acordo de Basileia I nos Bancos localizados no Brasil. Os resultados obtidos pelos autores evidenciam que houve impacto do Acordo de Basileia I nos principais índices de lucratividade e rentabilidade dos bancos. Dessa forma, é possível concluir que o Acordo de Basileia I teve impacto financeiro negativo nos bancos localizados no Brasil.

\subsubsection{Acordo da Basileia II}

Apesar da contribuição dada para a estabilidade do sistema financeiro mundial, o Acordo de Basileia I não foi o suficiente para conter novas crises que abalaram a estrutura desse sistema. Dessa maneira, após um período de discussões e a publicação de versões para consulta em 1999, em 2001 e em 2003, surge, no ano de 2004, a nova estrutura do Acordo de Basileia, doravante chamada de Basileia II. (MENDONÇA, 2004). 
Para Xavier (2003, p. 90), a principal mudança do acordo Basileia II, “[...] diz respeito à possibilidade dos bancos desenvolverem seus próprios modelos internos para adequação do capital. O acordo de 1988 vedava tal possibilidade [...]". Desse modo, deve haver um controle da qualidade desses modelos, que segundo o autor, “[...] deverá ser exercido em conjunto, tanto pelo órgão supervisor quanto pelos demais participantes do mercado [...]."

A Basileia II está baseada em uma estrutura que foi construída em três pilares. O trabalho de Mendonça (2004, p. 31-36) detalha cada um desses pilares, que serão apresentados resumidamente abaixo:

A. Pilar 1 - Os requerimentos mínimos de capital: a taxa mínima de capital foi mantida, não podendo ser menor do que $8 \%$. Para fins de cálculo da taxa de capital, além dos riscos de crédito e de mercado que constavam no original, introduziu-se o risco operacional. Para a mensuração desses riscos, foram introduzidas três formas distintas para cálculo.

B. Pilar 2 - Processo de revisão da supervisão: para garantir a sustentabilidade do Pilar 1, os órgãos de supervisão devem realizar uma avaliação do sistema de alocação de capital dos bancos, para assegurar que a posição de capital seja consistente com o perfil e as estratégias de riscos. As autoridades podem exigir que os bancos operem acima dos índices mínimos de capital, impondo um novo valor percentual. Cabe aos supervisores intervirem caso o banco fique abaixo do necessário para suportar os riscos assumidos.

C. Pilar 3 - Disciplina de mercado: a principal ideia desse pilar é desenvolver regras que estimulem e requeiram uma maior abertura de informações quanto ao perfil de riscos e o nível de capitalização dos bancos, fazendo com que os agentes participantes do mercado passem a fazer essa exigência das instituições.

Assim, a Basileia II, por meio do Pilar 3, passa a exigir um disclosure maior das instituições financeiras, com um padrão assegurado pelos órgãos reguladores do setor. $\mathrm{O}$ trabalho desenvolvido por Doornik et al. (2007) objetivou avaliar o nível de aderência do sistema financeiro brasileiro aos requerimentos de disclosure da Basileia II. Para isso, os autores analisaram a transparência das demonstrações contábeis dos dez principais bancos brasileiros, no período de 2003 a 2005. O estudo concluiu que o grau de transparência das demonstrações 
contábeis publicadas pelos principais bancos brasileiros a partir de 2001, de acordo com os critérios de divulgação estabelecidos pelo Comitê no Acordo de Basileia 2, ainda não atendem às recomendações internacionais, satisfatoriamente.

\subsubsection{Sarbanes-Oxley e controles internos}

Após os escândalos contábeis das companhias Enrol e Wordcom, em 2001, surge uma lei sancionada pelo presidente dos Estados Unidos em julho de 2002: a Lei Sarbanes-Oxley. Essa lei afeta, principalmente, a forma de divulgação das informações e situação econômicofinanceira das empresas, impondo a criação de controles internos eficazes. As empresas que negociam ações no mercado norte-americano são obrigadas a seguir essa lei, o que afeta um grupo de empresas no Brasil. A CVM e o BACEN divulgaram normas que seguem a lei Sarbanes-Oxley, exigindo, principalmente, controles internos eficientes para assegurar boas práticas de Governança Corporativa.

Quanto aos controles internos, o COSO (Comittee of Sponsoring Organizations of the Treadway Commission) instituiu, em 1992, um modelo denominado Internal Control Integrated Framework, atualizado em 1994 e conhecido hoje por COSO 1. O comitê, ainda, define controle interno como um processo, operado pelo conselho de administração ou outras pessoas. Esse processo é feito para promover, com uma segurança aceitável, a eficácia e eficiência das informações, a confiabilidade das informações financeiras e compliance às leis e regulamentos aplicáveis ${ }^{1}$.

Santos (2004, p. 61) relaciona o conceito de Controles Internos aos conceitos fundamentais, resumidos abaixo:

- $\quad$ O controle interno é um processo, não sendo um evento ou circunstância. Os controles internos são mais eficazes quando são construídos dentro da estrutura da organização, tornando-se parte da sua essência;

- Os controles internos são conduzidos por pessoas. Dessa forma, deve-se desenvolver uma cultura de controles desde mais elevados níveis hierárquicos até as unidades operacionais básicas;

\footnotetext{
${ }^{1}$ Definição disponível em: <WWW.coso.org>. Acesso em: 14/09/2008.
} 
- O controle interno deve incorporar métricas e métodos de mensuração que possibilitem avaliar o desempenho e os riscos que cercam as atividades da organização. Deve estar voltado para atender os objetivos estratégicos da empresa;

- O controle não é apenas para apurar se metas foram atingidas, mas, também, para verificar a relação de causa e efeito do desempenho apresentado e sua conexão com os riscos assumidos.

Muito se discute a respeito dos Controles Internos como uma área que atua dentro da Controladoria de uma instituição. Esse assunto será tratado nos próximos capítulos, no relacionamento das atividades e funções da Controladoria em Instituições Financeiras.

\subsection{Estrutura conceitual básica de controladoria}

O trabalho desenvolvido por Borinelli (2006) buscou, partindo-se de uma análise crítica e argumentativa sobre os textos de Controladoria, organizar, sistematicamente, a ECBC. O constructo formado para organizar a ECBC partiu do entendimento do conceito de teoria, suas funções e objetivos, bem como todos os critérios que denotam a construção de uma teoria. Desse modo, o autor organizou a ECBC em três abordagens, conforme denominações abaixo:

- Perspectiva 1: mostra "o que é” a Controladoria, enquanto ramo do conhecimento.

- Perspectiva 2: aborda os aspectos procedimentais, o "como funciona" da Controladoria.

- Perspectiva 3: como a Controladoria se materializa nas organizações.

Essa metodologia de abordar a controladoria em perspectivas segue a definição de Controladoria proposta por Catelli (2001, p. 344), ao salientar que "A Controladoria não pode ser vista como um método, voltado ao como fazer." O autor aponta que:

[...] devemos cindi-la em dois vértices: o primeiro como ramo do conhecimento responsável pelo estabelecimento de toda base conceitual, e o segundo como órgão administrativo respondendo pela disseminação de conhecimento, modelagem e implantação de sistemas de informações. 
O trabalho de Borinelli (2006) expandiu esse conceito, abrindo-o nas três perspectivas apresentadas. A Figura 1, a seguir, é uma estruturação criada por Borinelli (2006), com o objetivo de demonstrar a integração entre as três perspectivas analisadas. Para Borinelli (2006, p. 97), “[...] a ilustração, em forma de cubo, contemplando as três abordagens, evidencia que a Controladoria pode ser estudada ou compreendida de diferentes maneiras, dependendo da perspectiva com que se olha."

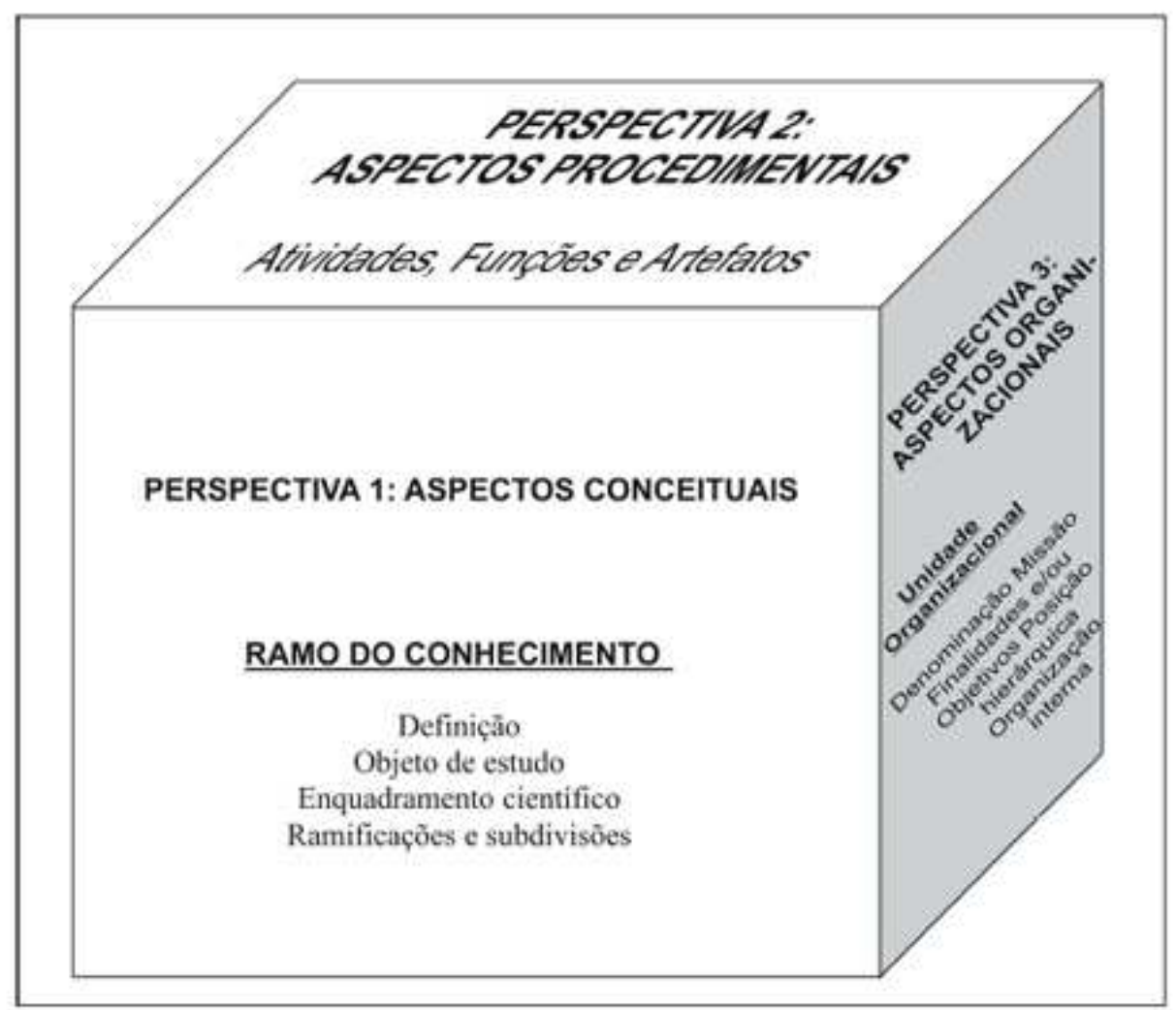

Figura 1 - Visão esquemática das perspectivas de estudo da controladoria Fonte: Borinelli (2006, p. 97)

As próximas seções dedicam-se a exibir, detalhadamente, cada perspectiva da ECBC elaboradas por Borinelli (2006). A Perspectiva 1 (Aspectos Conceituais) não será foco de um estudo aprofundado para este trabalho, tendo em vista que o principal objetivo é verificar a prática da Controladoria pelos bancos que operam no Brasil. Para atender esse objetivo, tornase necessário um estudo mais aprofundado da Perspectiva 2 (Aspectos Procedimentais), devido a certas características das instituições financeiras que podem diferenciar as funções e atividades da Controladoria com relação às demais empresas. Dessa forma, a seção que aborda a Perspectiva 2 terá uma análise complementar, voltada para instituições financeiras, para que se possam entender melhor as respostas obtidas na pesquisa de campo. 


\subsection{1 $\quad$ ECBC - Perspectiva 1: aspectos conceituais}

Ao caracterizar a perspectiva 1 como aspectos conceituais, procura-se obter resposta para a pergunta "o que é?" a respeito da Controladoria, porém, conforme relatado por Borinelli (2006, p. 101), não será um trabalho fácil, pois, segundo o autor, “[...] já nessa empreitada encontram-se as primeiras dificuldades, uma vez que não se tem consenso entre os autores [...]."

Borinelli (2006, p. 105), após um extenso levantamento da literatura que aborda Controladoria, bem como suas considerações e críticas, chega a uma definição para Controladoria tal como "[...] um conjunto de conhecimentos que se constituem em bases teóricas e conceituais de ordens operacional, econômica, financeira e patrimonial, relativas ao controle do processo de gestão organizacional." A definição proposta pelo autor deixa opções de interpretações para o conceito, uma vez que o processo de gestão organizacional pode ser diferente dentre as mais diversas formas de organizações existentes.

Além da definição de Controladoria, um ponto importante a ser analisado é o seu objeto de estudo. Dessa maneira, procura-se encontrar seu campo de aplicação ou o enfoque de suas atividades e funções. Verifica-se que não há consenso entre os autores sobre o objeto de estudo da Controladoria.

Borinelli (2006, p. 106-109) realiza um levantamento da literatura a respeito dos objetos de estudo da Controladoria. Dentre os divergentes conceitos encontrados e diferentes pontos de vista, o autor deduz que "[...] o objeto de estudo da Controladoria são as organizações, ou seja, o modelo organizacional como um todo [...]." Assim, o autor divide o objeto de estudo da Controladoria em três focos de atuação: O Modelo de Gestão, o Modelo de Decisão e o Modelo de Informação. Para o autor, esses três modelos conduzem ao processo de formação do resultado.

Para Carvalho (1995, p. 62), a Controladoria, enquanto campo de conhecimentos, “[...] está preocupada, fundamentalmente, com a gestão econômica do empreendimento, medindo-se a utilidade das teorias e modelos que se propõe usar por sua contribuição à garantia da eficácia dessa gestão [...]." Desse modo, o autor limita o objeto de estudo da Controladoria ao resultado econômico das firmas. Os bancos são considerados entidades dentro do universo de organizações mencionadas por Borinelli (2006) no parágrafo anterior, sendo seu conceito de 
objeto de estudo da Controladoria muito mais amplo que Carvalho (1995) e adequado para compor a ECBC e a pesquisa empírica deste trabalho.

Deve-se ressaltar, entretanto, que a definição de Controladoria na ECBC apresentada por Borinelli (2006), apesar de ter um conceito amplo, foi baseada em um levantamento bibliográfico em que o próprio autor mencionou não haver consenso entre as definições. Como não há uma consolidação teórica sobre a Controladoria, sua definição pode ser alvo de críticas entre pesquisadores. Apresentar uma definição de Controladoria não está entre os objetivos deste trabalho e, sendo assim, adota-se a definição apresentada por Borinelli (2006) em sua ECBC. A próxima seção trata dos aspectos procedimentais da Controladoria, que, dentre as três perspectivas estudadas, é o foco de maior atenção para esta pesquisa.

\subsubsection{ECBC - Perspectiva 2: aspectos procedimentais}

Após apresentar, brevemente, os aspectos conceituais da Perspectiva 1, elaborada por Borinelli (2006), nesse tópico, que trata dos Aspectos Procedimentais da Controladoria, pretende-se discutir quais são as atividades, funções e artefatos de que a Controladoria se utiliza para se materializar nas instituições. Para atingir objetivos específicos do presente trabalho, torna-se necessário uma visão crítica dessa Perspectiva 2, que inclui uma análise das funções e atividades da Controladoria focadas nas características das entidades bancárias.

O que se propõe, nesse capítulo, não é compreender quais as funções e atividades realizadas pela Controladoria dos bancos, mas, sim, apresentar as funções e atividades típicas da Controladoria elencadas na ECBC, com uma visão voltada às atividades dos bancos. Tendo em vista o extenso trabalho de Borinelli (2006) para pesquisar os diferentes textos que discutem controladoria com suas funções e atividades, na Tabela 4, a seguir, relacionam-se as atividades mais citadas, segundo a literatura consultada pelo autor. Essa pesquisa teve um total de 28 (vinte e oito) autores nacionais e 19 (dezenove) estrangeiros pesquisados. 
Tabela 4 - Resumo das atividades de controladoria mais citadas, segundo a literatura

\begin{tabular}{|c|c|c|}
\hline \multirow{2}{*}{ Atividades } & \multicolumn{2}{|c|}{ Autores em \% } \\
\hline & Brasileiros & Estrangeiros \\
\hline Gerenciar o Departamento de Contabilidade & 29 & 21 \\
\hline Desenvolver e gerenciar o sistema contábil de informação & 14 & 32 \\
\hline Implementar e manter todos os registros contábeis & 21 & 58 \\
\hline Elaborar demonstrações contábeis & 25 & 58 \\
\hline Atender aos agentes de mercado (preparar informações) & 36 & 47 \\
\hline Realizar o registro e controle patrimonial (ativos fixos) & 14 & 32 \\
\hline Gerenciar impostos (registro, recolhimento, supervisão etc.) & 25 & 37 \\
\hline Desenvolver e gerenciar o sistema de custos & 29 & 42 \\
\hline Realizar auditoria interna & 25 & 26 \\
\hline Desenvolver e gerenciar o sistema de informações gerenciais & 82 & 11 \\
\hline Prover suporte ao processo de gestão, com informações & 79 & 63 \\
\hline Coordenar os esforços dos gestores das áreas (sinergia) & 39 & 11 \\
\hline $\begin{array}{l}\text { Elaborar, coordenar e assessorar na elaboração do planejamento da } \\
\text { organização (agrupadas) }\end{array}$ & 36 & 32 \\
\hline $\begin{array}{l}\text { Elaborar, coordenar, consolidar e assessorar na elaboração do } \\
\text { orçamento das áreas (agrupadas) }\end{array}$ & 29 & 58 \\
\hline $\begin{array}{l}\text { Desenvolver, acompanhar e assessorar o controle do } \\
\text { planejamento/orçamento (agrupadas) }\end{array}$ & 39 & 47 \\
\hline Desenvolver políticas e procedimentos contábeis e de controle & 11 & 37 \\
\hline
\end{tabular}

Fonte: Borinelli (2006, p. 133)

$\mathrm{Na}$ Tabela 4, é possível observar que a literatura nacional apresenta como atividade mais citada da Controladoria o desenvolvimento e gerenciamento do sistema de informações gerenciais $(82 \%)$, seguido do suporte ao processo de gestão, com informações (79\%). Já a literatura estrangeira abrange um maior número de atividades, com maior participação em cada atividade listada na tabela.

Para efeitos da ECBC, após listar as atividades da Controladoria encontradas na literatura, Borinelli (2006, p. 135-139) parte para organizar as atividades em funções da Controladoria. Abaixo um resumo das funções típicas da Controladoria elencadas pelo autor:

- Função contábil: relativa ao desenvolvimento da Contabilidade Societária (ou Financeira), tais como: gerenciar as atividades, manter os registros, elaborar 
demonstrações contábeis, atender aos agentes de mercado e desenvolver políticas e procedimentos contábeis e de controle.

- Função gerencial-estratégica: promover informações de natureza contábil, patrimonial, econômica, financeira e não financeira ao processo de gestão como um todo, para a tomada de decisão gerencial e estratégica. Além disso, ainda estão incluídas as atividades: coordenar, assessorar e consolidar os processos de elaboração dos planos empresariais, orçamento e previsões; criar condições para a realização do controle, por meio do acompanhamento dos planos e das decisões tomadas; auxiliar na definição de métodos e processos para medição do desempenho das áreas organizacionais, estudos de viabilidade econômica de projetos, entre outras.

- Função de custos: registrar, mensurar, controlar, analisar e avaliar os custos da organização como um todo, incluindo análise de viabilidade de lançamento de produtos e serviços.

- Função tributária: atender obrigações fiscais, legais e acessórias previstas em leis e normas tributárias, bem como registrar, apurar e controlar impostos.

- Função de proteção e controle dos ativos: registrar e controlar todos os bens da organização.

- Função de controle interno: estabelecimento e monitoramento do sistema de controles internos destinado a proteger o patrimônio organizacional, bem como encorajar e estimular a obediência e aderência às diretrizes e políticas internas, obtendo conformidade e aderência com as leis e regulamentos (compliance).

- Função de controle de riscos: identificar, mensurar, analisar, avaliar, divulgar e controlar os diversos riscos envolvidos no negócio, bem como seus possíveis efeitos.

- Função de gestão da informação: conceber modelos de informações e gerenciar as informações contábeis, patrimoniais, de custos, gerenciais e estratégicas.

- Outras funções: estariam as de auditoria interna e tesouraria, por exemplo. 
A respeito das outras funções mencionadas, Borinelli (2006, p. 179) enumera funções da auditoria interna dentro da organização e conclui que:

[...] a ECBC contempla como atividades de Controladoria tanto aquelas relativas ao controle interno quanto as de auditoria interna. Porém, como se explicou, estas últimas não devem ser desempenhadas pela mesma unidade organizacional que desempenha as primeiras, pela necessidade de se segregar funções.

Ao apresentar as atividades agrupadas em funções, conforme explicado pelo próprio autor que "[...] para efeitos da ECBC optou-se por organizar as atividades encontradas na literatura dentro de suas respectivas funções." (Ibid., p. 135), corre-se o risco de fazer interpretações erradas ao verificar quais as funções estão sob a Controladoria nas organizações. A função de controle de riscos, por exemplo, pode ter uma complexidade muito grande para bancos, sendo que a Controladoria pode exercer algumas atividades que estejam relacionadas ao risco, mas não todas elas. Dessa forma, poderia concluir, erroneamente, que a função de controle de riscos não está sob a Controladoria nos bancos.

Algumas funções da Controladoria podem estar num processo de migração nas entidades, uma vez que outras áreas surgem com o propósito para assumir essas funções. É o caso, por exemplo, de funções de sistemas de informações e auditoria interna, conforme explicam Schnorrenberger et al. (2007, p. 7). Áreas de TI e de Auditoria Interna podem agregar essas funções, deixando-as fora da Controladoria.

Por não se ter encontrado outra maneira de apresentar as funções da Controladoria, se não por esse agrupamento de atividades, a opção por essa sistematização será aceita para o desenvolvimento deste trabalho. Para evitar problemas de interpretação equivocada sobre funções que estejam ou não sob a responsabilidade da Controladoria, ao apresentar os resultados da pesquisa empírica, algumas atividades dentro de uma função poderão ser destacadas e comentadas separadamente.

\subsubsection{Atividades e funções da controladoria no processo de gestão}

O trabalho de Borinelli (2006) procurou investigar, após elencar as funções e atividades da Controladoria para compor a ECBC, o papel da Controladoria em cada etapa do processo de gestão: planejamento, orçamento, execução e controle. O mérito para esse estudo é, segundo o 
autor, a importância que a literatura atribui à Controladoria relacionada a esses elementos. Para este trabalho, buscou-se revisar as análises de Borinelli (2006), apresentando características do setor bancário que podem influenciar as atividades e funções da Controladoria em cada etapa do processo de gestão.

O Quadro 1 apresenta um resumo das funções e atividades da Controladoria nos processos de gestão, dividido por etapas, conforme estudo realizado por Borinelli (2006). Note-se que, apesar do planejamento estar dividido em estratégico, tático e operacional, o autor considera os três níveis de planejamento como um processo integrado para fins de ECBC.

Quadro 1 - Funções e atividades da controladoria no processo de gestão

\begin{tabular}{|c|c|}
\hline $\begin{array}{l}\text { PROCESSO DE } \\
\text { GESTÃO }\end{array}$ & FUNÇÕES/ATIVIDADES \\
\hline \multirow{4}{*}{ PLANEJAMENTO } & $\begin{array}{l}\text { Participar das definições dos objetivos estratégicos, tomando decisões em conjunto } \\
\text { com demais gestores, sendo coordenadora do processo }\end{array}$ \\
\hline & Coordenar o processo de construção do plano em nível operacional \\
\hline & $\begin{array}{l}\text { Assessorar as diversas unidades com informações de caráter operacional, } \\
\text { econômico, financeiro e contábil }\end{array}$ \\
\hline & $\begin{array}{l}\text { Consolidar os diversos planos das unidades num planejamento global integrado e } \\
\text { otimizado }\end{array}$ \\
\hline \multirow{5}{*}{ ORÇAMENTO } & Coordenar o processo de Construção do Orçamento \\
\hline & $\begin{array}{l}\text { Determinar, em conjunto com a administração e demais áreas, as premissas e } \\
\text { diretrizes orçamentárias }\end{array}$ \\
\hline & Assessorar as demais áreas na elaboração dos seus orçamentos \\
\hline & Consolidar os orçamentos das áreas em um orçamento global \\
\hline & $\begin{array}{l}\text { Avaliar os orçamentos das áreas, a fim de verificar se atendem as definições dos } \\
\text { planos estratégicos, tático e operacional }\end{array}$ \\
\hline \multirow{4}{*}{ EXECUÇÃO } & Auxiliar as áreas na aplicação dos recursos planejados \\
\hline & Dar suporte às áreas na implementação dos projetos \\
\hline & $\begin{array}{l}\text { Coordenar os esforços dos gestores das diversas áreas na consecução dos seus } \\
\text { respectivos objetivos }\end{array}$ \\
\hline & Fornecer apoio informacional sobre o andamento dos planos \\
\hline \multirow{6}{*}{ CONTROLE } & $\begin{array}{l}\text { Gerar informações que contemplem eventos planejados e realizados, para verificar } \\
\text { a aderência entre os planos e o real, inclusive com relatórios }\end{array}$ \\
\hline & Interagir com as demais áreas para identificar as causas dos desvios \\
\hline & Exercer, efetivamente, o controle \\
\hline & Garantir a eficácia do sistema de controle \\
\hline & Revisar, periodicamente, o sistema de controle \\
\hline & Coordenar o processo de controle \\
\hline
\end{tabular}

Fonte: Borinelli (2006) 
Ainda no processo de gestão, Borinelli (2006, p. 172) defende, para fins da ECBC, que "[...] considera-se coerente que, dentre as atividades da Controladoria esteja participar do processo de definição dos parâmetros da avaliação de desempenhos, sempre que for requisitada." O autor, também, atribui como função da Controladoria a mensuração dos parâmetros de desempenho, tanto das diversas funções e unidades organizacionais, quanto dos gestores das diversas áreas da entidade.

Tanto as funções gerais da Controladoria, quanto a sua atuação no processo de gestão, elencadas por Borinelli (2006) e que fazem parte da ECBC, se enquadram em qualquer tipo de organização, pois são funções típicas da Controladoria segundo a literatura pesquisada pelo autor. Mas algumas das funções devem ser destacadas e outras acrescentadas à ECBC, para que se possa realizar uma pesquisa empírica das práticas de Controladoria dos Bancos.

\subsection{3 $\quad$ ECBC - Perspectiva 3: aspectos organizacionais}

Após a abordagem das Perspectivas 1 e 2, o próximo passo dado por Borinelli (2006) foi de organizar a Perspectiva 3, que trata de entender como a Controladoria atua dentro das instituições: qual a definição da área dentro da empresa, os objetivos, sua organização interna e posição hierárquica no organograma.

Definir a Controladoria enquanto uma unidade organizacional pode ser uma difícil missão, especialmente ao se pensar em instituições financeiras. Dessa maneira, essa definição deve ser algo abrangente, capaz de se adaptar aos diversos tipos de organizações existentes. Alguns autores relacionam a Controladoria dentro da entidade como uma integradora de informações e uma ferramenta de assessoria para gestores.

A pesquisa realizada por Grande e Beuren (2008) objetivou identificar as abordagens do tema Controladoria em livros nacionais, mediante uma pesquisa exploratória, com abordagem qualitativa. Os autores verificaram que, quanto à Controladoria como unidade organizacional, poucos livros tratam da sua definição, missão e posição hierárquica.

Em um modelo proposto de Gestão Econômica (GECON), a Controladoria, conforme Parisi (2001, p. 280), “[...] pode ser entendida como um órgão administrativo comprometido com a identificação, mensuração, informação e gestão dos eventos econômicos que impactam uma 
entidade." Desse modo, o autor procura focar na Controladoria, no aspecto organizacional, os eventos econômicos da entidade.

Martin (2002, p. 15) afirma que, "Na verdade, para atender às necessidades de gestão moderna, a Controladoria precisa ser contínua e intrinsecamente estratégica, o que ela deve realizar sem perder jamais seu caráter de apoio operacional." Assim, o autor expõe que enquanto uma unidade organizacional, a Controladoria deve ser um órgão estratégico dentro da empresa, mas não pode perder suas funções "clássicas" de apoio às demais áreas da organização.

O trabalho de Carvalho (1995, p. 157) conclui que, no contexto das demandas de gestão econômica dos bancos, “[...] compete à Controladoria, enquanto órgão integrante da estrutura organizacional, exercer um conjunto de funções voltadas à otimização dessa gestão [...].” O autor destaca, entre essas funções, um sistema de informações gerenciais voltado para os resultados, garantir acesso das informações para a tomada de decisões, auxílio às demais áreas na gestão de resultados e coordenação da empresa em busca de otimizar o resultado.

A definição considerada adequada para este estudo, para que seja possível realizar uma pesquisa empírica atendendo os objetivos propostos, é a sugerida por Borinelli (2006, p. 198), que define a Controladoria, enquanto órgão do sistema formal das organizações, da seguinte forma:

Controladoria é o órgão do sistema formal da organização responsável pelo controle do processo de gestão e pela geração e fornecimento de informações de ordens operacional, econômica, financeira e patrimonial demandadas (i) para assessorar as demais unidades organizacionais durante todo o processo de gestão - planejamento, execução e controle - buscando integrar os esforços dos gestores para que se obtenha um resultado organizacional sinérgico e otimizado, bem como (ii) pelos agentes externos que se relacionam com a empresa, para suas tomadas de decisões.

Outra preocupação que a ECBC teve foi em posicionar, hierarquicamente, a Controladoria em uma entidade. Assim, Borinelli (2006) procurou entender se a Controladoria está ou deve estar subordinada, no organograma da entidade, e se ela é um órgão staff (que desempenha atividades e funções de apoio e assessoria) ou se exerce autoridade de linha.

Borinelli (2006, p. 213) verificou que “[...] mesmo que a ECBC considere que o órgão Controladoria deve estar subordinado diretamente à Presidência, na prática as organizações 
podem optar por um arranjo diferente, tendo em vista as definições do seu modelo de gestão [...]." Já o trabalho de Santos (2004, p. 175) propõe um esquema em que "A Controladoria teria de um lado uma ligação de natureza puramente informativa com os principais executivos da empresa [...]" e "Por outro lado, a Controladoria teria uma ligação de natureza hierárquica, que subordinaria o Controller diretamente ao Conselho de Administração." Diferentemente de Borinelli (2006), a autora procura certa independência da Controladoria em relação à gestão da empresa.

Segundo Nascimento e Bianchi (2005, p. 2), “[...] a área de controladoria de uma empresa pode representar um papel central na mediação dos conflitos entre seu principal e seus agentes.” Para os autores, “[...] espera-se da área de controladoria uma postura de defesa dos interesses dos proprietários da organização ou daqueles que os representam diretamente." Sendo assim, o Controller deve exercer um papel independente para boas práticas de Governança Corporativa.

No contexto de um Banco, o controle de riscos é totalmente estratégico para o negócio. Desse modo, Brito (2000, p. 28) corrobora que, nesse cenário, a Controladoria é:

[...] concebida como a área mais adequada e oportuna para ser responsável pelo sistema de controle de riscos, porque é um órgão neutro suficiente para julgar com independência e porque, tendo acesso às informações gerenciais, a consolidação e validação dessas informações são facilitadas.

Tal afirmação não vai contra a subordinação da Controladoria pela presidência, conforme determina a ECBC. Apenas demonstra que é um órgão que tem poder de julgamento de informações relacionadas ao risco.

Quanto ao nível de autoridade da Controladoria dentro de uma organização, a literatura considera as duas possibilidades: como um órgão de linha ou como um órgão de staff. Oliveira (2000, p. 148) define que os órgãos de linha são aqueles que participam das tomadas de decisões, sendo corresponsáveis por elas, e os órgãos de staff trabalham apenas como uma assessoria, oferecendo apoio para que outras áreas tomem suas decisões, sem participações. 
No que diz respeito à ECBC, Borinelli (2006, p. 217) afirma que:

[...] visando à consistência com os demais itens de tal estrutura, entende-se que a unidade organizacional Controladoria deve funcionar como órgão de linha, fazendo acontecer o processo de gestão e de tomada de decisão juntamente com os demais órgãos e funções da organização.

Assim, o autor coloca a Controladoria como um órgão de linha para a ECBC, mas não restringe a possibilidade dela atuar, também, como um órgão de staff, oferecendo apoio nas tomadas de decisões para outras áreas.

Ahrens e Chapman (2007, p. 22) afirmam que "As práticas de controladoria são centrais para a organização, porque elas ajudam a fazer conexões entre as diversas atividades dos membros da organização." Sendo assim, a Controladoria funcionaria como um órgão centralizado, organizando as atividades dos membros que estão separados na organização.

Deve-se atentar que, devido à diversidade de produtos e operações em um banco, pode haver a existência de uma descentralização da Controladoria, que pode estar dividida por unidade, por produto, por áreas, entre outros. A respeito disso, Borinelli (2006, p. 217) menciona que "No entanto, alguns cuidados devem ser observados, especialmente no que diz respeito ao nível de subordinação do órgão, tanto hierárquico quanto funcional.” Para a ECBC, o autor considera que, ao existir Controladoria Divisional, essa deve estar subordinada, hierarquicamente, à direção divisional e, funcionalmente, à Controladoria Corporativa.

\subsubsection{Funções e atribuições da controladoria em bancos}

O objetivo desse tópico é analisar, à luz da Perspectiva 2 (Aspectos Procedimentais) da ECBC, algumas características típicas de Bancos que podem acrescentar ou dar mais ênfase em certas funções e atividades da Controladoria. Deve-se ressaltar que o Capítulo 4 apresentará os resultados obtidos na pesquisa empírica realizada neste trabalho, o que poderá alterar ou até mesmo eliminar determinadas características descritas nesse tópico.

Um dos principais pontos que levam a Controladoria a ter características diferentes em bancos com relação aos demais tipos de empresas é a sua necessidade de mudanças estruturais para se adaptar aos novos mercados. Assim, mencionam Catelli et al. (2001, p. 359-360) que: 
[...] essas mudanças vão desde pequenos ajustes estruturais até a redução drástica de sua rede de distribuição; desde a redução de custos até a busca de novas fontes de receitas; desde a diversificação de suas atividades, por meio do desenvolvimento de novos produtos e serviços, até a concentração em determinados mercados e segmentos; desde o ajuste de seus planos até mesmo à revisão de sua missão e de seus propósitos básicos.

Em consequência disso, os autores afirmam que "[...] os gestores das instituições financeiras encontram-se diante de novos desafios." Assim, também, é para definir ao certo as funções e atividades da Controladoria, bem como seus limites nas instituições financeiras: um desafio.

Considerando que certos aspectos peculiares dos bancos possam configurar como um desafio para a Controladoria, Chagas (2000, p. 44-51) abordou características desse tipo de entidade, que serão resumidas abaixo:

A. Riscos: Para o autor, a intermediação financeira apresenta graus variados de incerteza quanto aos resultados futuros, representando altos riscos. Dessa maneira, o autor afirma que uma das preocupações do Controller é a mensuração desses riscos, especialmente os decorrentes de descasamentos desfavoráveis, bem como a representatividade dos seus efeitos sobre o resultado da instituição.

B. Rede de atendimento e unidades de apoio: Os produtos e serviços bancários são oferecidos ao púbico, em grandes e diferentes volumes, distribuídos em diversos pontos de atendimento no país e no exterior. Os gestores desses pontos de atendimento não possuem autonomia para decisões de caráter econômico, ficando a cargo da administração central. Para o autor, há um aumento da complexidade para avaliação do resultado, dos produtos e serviços, bem como do desempenho dos gestores.

C. Produtos e serviços: A grande variedade de produtos e serviços e sua rápida criação pelo mercado podem ser consideradas como um grande obstáculo. Os produtos e serviços transferidos entre as áreas da empresa não são identificados com facilidade, dificultando a mensuração do valor agregado pelas diversas áreas.

D. Produção conjunta: Alguns produtos das instituições financeiras utilizam os mesmos fatores de produção. Por exemplo, um funcionário e um equipamento podem criar diversos produtos. Pode ocorrer, também, a participação de diversas áreas em um único 
produto. Assim, a Controladoria passa a ter uma grande dificuldade no reconhecimento de receitas e custos para analisar o resultado do produto e até mesmo das áreas.

E. Sazonalidade: Alguns produtos e serviços são utilizados pela população em certas épocas específicas ou de acordo com incentivos do governo. Desse modo, a Controladoria deve fornecer informações ágeis às áreas responsáveis, verificando as implicações no resultado da instituição.

F. Alta regulamentação: A alta regulamentação do setor, conforme o autor, constitui-se em mais um desafio para a Controladoria. Grandes mudanças podem ser necessárias dentro da instituição, para que ela se adapte a uma nova regra emitida. A Controladoria deve estar preparada para atender os órgãos reguladores, já prevendo todo o impacto nos resultados da instituição.

G. Complexidade e dificuldade de operação dos sistemas: $\mathrm{O}$ desenvolvimento dos sistemas foi realizado em períodos diferentes. Dessa forma, com a modernização dos sistemas, tornam-se necessárias mudanças nos sistemas de informações existentes nessas instituições. A Controladoria pode ter como uma barreira, a dificuldade de relacionar-se com a complexidade de obtenção de dados e recuperação de informações.

H. Credibilidade: Para o autor, "Sem que a Controladoria disponha de instrumentos que permitam exercitar a sua capacidade de persuasão e facilitem o seu processo de comunicação, seus modelos podem cair no descrédito." O desafio do Controller em uma instituição financeira é grande, sendo que erros da Controladoria podem ocasionar grandes prejuízos.

As características do setor bancário apresentadas acima estão, de alguma forma, relacionadas com as atividades da Controladoria nessas instituições. Sendo assim, Chagas (2000, p. 125134) identificou diversas funções da Controladoria praticada por instituições bancárias que atuam no Brasil. A Tabela 5, a seguir, apresenta as principais funções elencadas pelo autor, com as atividades básicas atribuídas à Controladoria. 
Tabela 5 - Principais funções da controladoria para bancos

\begin{tabular}{l|l}
\multicolumn{1}{c|}{ Função } & \multicolumn{1}{c}{ Atividades da Controladoria } \\
\hline $\begin{array}{l}\text { Apuração de Resultados } \\
\text { Gerenciais e Avaliação de } \\
\text { Desempenhos }\end{array}$ & $\begin{array}{l}\text { Apuração, controle e análise de custos, margens } \\
\text { financeiras e resultados das unidades de negócios e } \\
\text { administrativas }\end{array}$ \\
\hline Compliance & Verificação da conformidade de normas \\
\hline Contabilidade Societária & $\begin{array}{l}\text { Controle do plano de contas e preparação das } \\
\text { demonstrações }\end{array}$ \\
\hline Contabilidade Gerencial & $\begin{array}{l}\text { Estudos de cenários e tendências, análise da } \\
\text { concorrência e estudo dos processos }\end{array}$ \\
\hline Estratégica & Gestão dos sistemas para tomadas de decisões \\
\hline Orçamento & $\begin{array}{l}\text { Coordenação do processo de orçamento e } \\
\text { consolidação das informações }\end{array}$ \\
\hline Risco & $\begin{array}{l}\text { Mensuração, avaliação e controles dos riscos, além } \\
\text { de avaliação dos riscos de mercado, riscos de crédito, } \\
\text { entre outros }\end{array}$ \\
\hline Simulações/Projeções de & $\begin{array}{l}\text { Análise de viabilidade de projetos, produtos, } \\
\text { serviços, novas agências e investimentos }\end{array}$ \\
\hline Resultado & $\begin{array}{l}\text { Planejamento tributário, cálculos e gestão dos } \\
\text { impostos }\end{array}$ \\
\hline Contabilidade Tributária & Realizar atividades de auditoria interna na instituição \\
\hline Auditoria Interna &
\end{tabular}

Fonte: Adaptado de Chagas (2000, p. 124-134)

Dentre as funções apresentadas por Chagas (2000, p. 124-134), destaca-se o orçamento. Frezatti (2006, p. 44), define orçamento como “[...] um dos pilares da gestão e uma das ferramentas fundamentais para que o accountability, a obrigação dos gestores de prestar contas de suas atividades, possa ser encontrado." Para Espejo (2008, p. 73), esse processo "[...] pode ser compreendido como um instrumento contábil que auxilia nos processos de planejamento e controle organizacionais."

O trabalho elaborado por Vieira e Hoskin (2005) é um estudo de caso sobre mudanças no sistema de Controladoria de um banco português. Os autores argumentam que o sistema de Controladoria tradicional está voltado, amplamente, para o orçamento, ligado a um processo de objetivos e incentivos. Esse sistema está relacionado, principalmente, a áreas comerciais, porém, o banco não tinha capacidade para calcular a margem por produtos, podendo incorrer em incentivos errados. Sendo assim, optou-se por alterações na estrutura de Controladoria do banco, implementando o Activity Based Costing (ABC). 
Corroborando Vieira e Hoskin (2005), para Schwarze et al. (2008, p. 1) os bancos estão enfrentando grandes desafios para implantar métodos de mensuração de performances que sejam inovadores, baseados no lucro econômico e, para isso, são necessárias mudanças na Controladoria das instituições. Os autores estudaram mudanças nas estruturas de Controladoria de bancos alemães, austríacos e suíços, para que possam se adaptar às novas exigências do mercado.

De acordo com Vieira e Hoskin (2005, p. 6): "O setor bancário está bem relacionado ao ABC, que foca os custos excedentes, os quais sempre são atrativos." ${ }^{2}$ (Tradução livre). Com a implementação do ABC na Controladoria, Vieira e Hoskin (2005, p. 14) afirmam que: "O controle dos custos tornou-se um processo-chave no banco e o $\mathrm{ABC}$ apresentou-se como uma ferramenta para distribuir os incentivos de uma forma mais consciente."3 (Tradução livre). Os autores concluem que, com a nova forma de controle de custos, a contabilidade no banco passou a ter maior importância, pois passou a ser diretamente relacionada aos bônus de remuneração. Esse trabalho destaca o mérito do controle de custos em uma instituição financeira, que afeta não só os resultados contábeis do banco, como a remuneração dos vendedores de produtos.

Focando outro ponto importante nas instituições financeiras, Brito (2000, p. 28) argumenta que a Controladoria deve migrar da análise do retorno obtido, ou seja, uma análise de acontecimentos passados, para a análise do retorno em condições de risco e alocação de capital. Dessa maneira, o autor atribui à Controladoria o controle do risco nos bancos, mencionando a tridimensionalidade abaixo, na qual a Controladoria deve atuar da seguinte forma:

1. Coleta de dados: a respeito do uso dos recursos (custos e receitas) e do risco na utilização dos recursos.

2. Preparação das demonstrações financeiras: incorporar medidas de risco, ao lado das medidas de rentabilidade.

\footnotetext{
2 "Banking is a sector where approaches like ABC, with its focus on making overhead costs visible, where aways likely to be seen as attractive."

3 "Control os costs had become a key issue in the bank and $A B C$ was seen as a potential device to induce behavioural incentives to be more cost conscientious."
} 
3. Análise de desempenho: prover medidas simultâneas, bidimensionais de retorno e risco em cada produto e linha operacional do banco.

Defendendo essa estruturação, Brito (2000, p. 29) afirma que:

A controladoria é aqui concebida como a área mais adequada e oportuna para ser a responsável pelo sistema de controle de riscos, porque é um órgão neutro o suficiente para julgar com independência e porque, tendo acesso às informações gerais, a consolidação e validação dessas informações são facilitadas.

Entende-se, então, que uma das atribuições da Controladoria para Bancos é a Gestão dos diversos tipos de riscos a que os bancos estão expostos. Além de defender que a Controladoria tem uma grande importância no Controle de Riscos nas instituições financeiras, Brito (2000, p. 60) destaca, nesse mesmo trabalho, as atividades básicas da Controladoria em Bancos de Atacado (seu foco de estudo), elencando em quatro itens, resumidos abaixo:

1. Elaborar, implantar e gerir o sistema de informações contábeis e gerenciais, acompanhando as metas estabelecidas, consolidação do processo orçamentário, análise de desempenho e informações financeiras para suporte à tomada de decisões.

2. Preparar e fornecer informações para as autoridades reguladoras, tal como BACEN, CVM, SUSEP, entre outras.

3. Responsabilidade pela Contabilidade, tanto na definição de políticas internas, quanto pela integridade dos dados.

4. Acompanhar e atualizar os controles internos gerais da instituição.

Considera-se que essas funções podem ser aceitas como "clássicas" da Controladoria. O objetivo do autor foi apenas relacioná-las às atividades praticadas pelos bancos, entretanto, sem um detalhamento mais adequado de cada atividade. A incumbência pela Contabilidade, por exemplo, pode exigir uma definição muito grande de atribuições e que não foram elencadas pelo autor. Leva-se em conta, portanto, que seria uma responsabilidade por todos os processos envolvidos na Contabilidade do banco. 
O trabalho de Carvalho (1995, p. 147), focado no estudo da Controladoria em bancos classificados como múltiplos, atribui algumas funções e atividades da Controladoria dentro dessas instituições. A primeira grande função elencada pelo autor seria a criação e manutenção de um sistema de informações de gestão econômica, para avaliação de resultados e planejamento do banco, voltados para impactos no resultado. A segunda função está relacionada ao fluxo de informações dessa entidade, sendo de responsabilidade da Controladoria, que as informações cheguem aos gestores para tomadas de decisões. A terceira função está relacionada ao esforço dos gestores de diversas áreas para assegurar a eficácia empresarial, auxiliando as diversas áreas. Por fim, o autor menciona a responsabilidade de analisar os regulamentos expedidos pelos órgãos reguladores do mercado, que possam alterar os fatores que interagem na otimização do resultado, interagindo com as diversas áreas para as alterações que forem necessárias.

O trabalho elaborado por Pinheiro (2000, p. 123) destaca algumas funções da Controladoria para instituições financeiras de desenvolvimento. $\mathrm{O}$ autor menciona que a Controladoria deve efetuar análises comparativas com outros bancos, acerca de seus diversos índices. Também é de responsabilidade da Controladoria a administração dos sistemas de projeções, orçamento, custos e resultados das unidades e produtos. Além disso, a Controladoria deve participar na definição de políticas de resultado do banco e na definição de critérios para a formação da base de dados do sistema de informações gerenciais.

Farias (1998, p. 82) afirma que:

[...] para o desempenho efetivo do seu papel nas instituições financeiras, a controladoria atua nas áreas econômica e financeira, e tem, sub sua responsabilidade, atividades que buscam subsidiá-las com todas as informações econômico-financeiras julgadas necessárias à tomada de decisão.

O autor destaca quatro atividades da Controladoria para as instituições financeiras. A primeira está focada em analisar e avaliar resultados e desempenho dos produtos e serviços, e dos desempenhos das unidades e dos gestores. A segunda, apurar custos e receitas que comporão o resultado de produtos, clientes e unidades. A terceira é a administração dos sistemas de informações gerenciais, promovendo a sua padronização. Por fim, a quarta atividade está em aferir e acompanhar as exposições do banco a riscos de mercado. 
Um ponto discutido por Farias (1998, p. 156-157), focado em instituições financeiras, é a análise de riscos. O autor menciona que "A análise de risco na formação de posições tem como objetivo principal demonstrar como se encontram os níveis de exposição do banco por meio de posições próprias nos diversos mercados em que atua." Também, afirma que "Cabe à controladoria disponibilizar instrumentos que permita a aferição da exposição a instituição a esses riscos." Concorda-se com o autor sobre o importante papel da Controladoria no processo de gestão de riscos. Adicionalmente, a Controladoria deve assumir nas instituições financeiras um importante papel na gestão dos diversos tipos de riscos. Dentre eles, com maior destaque para: risco de mercado, risco de liquidez, risco de crédito e o risco operacional.

O Quadro 2 contempla as atividades da Controladoria, agrupadas em funções, consolidando as funções e atividades elencadas por Borinelli (2006) da perspectiva 2 da ECBC, com a revisão da literatura de Controladoria com foco em bancos. Dessa forma, tem-se a base para a pesquisa empírica, realizada neste trabalho, das funções e atividades da Controladoria para Bancos.

Quadro 2 - Resumo das funções e atividades da controladoria para bancos

\begin{tabular}{|c|c|}
\hline FUNÇÃO & ATIVIDADES \\
\hline \multirow{3}{*}{ CONTÁBIL } & Controle do plano de contas \\
\hline & Definição das políticas contábeis \\
\hline & Preparação, consolidação e divulgação das demonstrações contábeis \\
\hline \multirow{3}{*}{ FISCAL } & Apuração, conferência e recolhimento dos impostos \\
\hline & Planejamento tributário \\
\hline & Gestão e controle de impostos \\
\hline \multirow{4}{*}{$\begin{array}{c}\text { RISCOS E CONTROLES } \\
\text { INTERNOS }\end{array}$} & Auditoria interna \\
\hline & Implantação e gestão dos controles internos do banco \\
\hline & Gestão dos riscos (mercado, liquidez, crédito e operacional) \\
\hline & Acompanhamento da Basileia \\
\hline \multirow{4}{*}{ FINANÇAS } & Gestão financeira e de tesouraria \\
\hline & Controle do fluxo de caixa \\
\hline & Análise dos índices do balanço \\
\hline & Análise dos índices dos concorrentes \\
\hline \multirow{3}{*}{$\begin{array}{l}\text { SISTEMAS DE } \\
\text { INFORMAÇÕES }\end{array}$} & Gestão dos sistemas de informação em geral \\
\hline & Gestão das informações gerenciais \\
\hline & Produção e geração de informações \\
\hline
\end{tabular}




\begin{tabular}{|c|c|}
\hline FUNÇÃO & ATIVIDADES \\
\hline \multirow{4}{*}{$\begin{array}{c}\text { ATENDIMENTO A } \\
\text { USUÁRIOS EXTERNOS }\end{array}$} & Atender acionistas \\
\hline & Atender governo \\
\hline & Atender auditoria externa \\
\hline & Atender órgãos reguladores (BACEN, CVM etc.) \\
\hline \multirow{2}{*}{ CUSTOS } & Mensuração dos custos para fins gerenciais \\
\hline & Análise e controle dos custos \\
\hline \multirow{2}{*}{ PLANEJAMENTO } & Elaboração do planejamento estratégico do banco \\
\hline & Controle do planejamento estratégico do banco \\
\hline \multirow{2}{*}{ ORÇAMENTO } & Elaboração do orçamento empresarial do banco \\
\hline & Controle do orçamento empresarial do banco \\
\hline \multirow{2}{*}{$\begin{array}{l}\text { AVALIAÇÃO DE } \\
\text { DESEMPENHO }\end{array}$} & Avaliação do desempenho de gestores \\
\hline & Avaliação do desempenho de produtos e serviços \\
\hline
\end{tabular}

A ECBC, elaborada por Borinelli (2006), é uma estrutura que tem um conceito amplo, capaz de abranger qualquer tipo de entidade e, por tal motivo, é aceita para a utilização na pesquisa empírica deste trabalho. A revisão sobre funções e atribuições de Controladoria voltadas para bancos, apresentada nessa seção, não conflita com a ECBC. Essa seção tem por finalidade complementar a ECBC, para que se possa fazer uma análise específica voltada para instituições financeiras. 


\section{TRAJETÓRIA DA PESQUISA}

\subsection{Introdução}

Nesse capítulo, apresenta-se a metodologia utilizada para esta pesquisa, bem como as técnicas para coleta e análise dos dados. Para que se possa alcançar o objetivo do trabalho, torna-se necessário uma metodologia de pesquisa, definida por Marconi e Lakatos (2005, p. 83) como "[...] conjunto das atividades sistemáticas e racionais que, com maior segurança e economia, permite alcançar o objetivo - conhecimentos válidos e verdadeiros -, traçando o caminho a ser seguido, detectando erros e auxiliando as decisões do cientista."

Corroborando Marconi e Lakatos (2005), Martins e Theóphilo (2007, p. 37) afirmam que "O objetivo da metodologia é o aperfeiçoamento dos procedimentos e critérios utilizados na pesquisa. Por sua vez, método (do grego méthodos) é o caminho para se chegar a determinado fim ou objetivo."

\subsection{Tipologia da pesquisa}

Inicialmente, para que se entenda a forma científica que se constitui esta pesquisa, torna-se necessário apresentar uma classificação da tipologia do estudo, dentro de determinadas categorias científicas.

Esta pesquisa tem como tipologia a natureza descritiva, assim definida por Martins (1994, p. 28): “[...] Descritiva: tem como objetivo a descrição das características de determinada população ou fenômeno, bem como o estabelecimento de relações entre variáveis e fatos [...]." Desse modo, este trabalho procura observar, registrar e analisar as práticas de Controladoria pelos maiores bancos que operam no Brasil, relacionando-as a uma revisão teórica do assunto. 
Corroborando a definição da pesquisa descritiva apresentada por Martins (1994), Salomon (1999, p. 158) descreve as pesquisas exploratórias e descritivas como:

[...] são as que têm por objetivo definir melhor o problema, proporcionar as chamadas intuições de solução, descrever comportamentos de fenômenos, definir e classificar fatos e variáveis. Não atingem ainda o nível da explicação nem o da predição, encontrados nas pesquisas "puras" ou "teóricas", nem o diagnóstico e/ou solução adequada do problema, deparados nas pesquisas "aplicadas".

Quanto à estratégia da pesquisa, Martins e Theóphilo (2007, p. 60) definem que "Os levantamentos são próprios para os casos em que o pesquisador deseja responder a questões acerca da distribuição de uma variável ou das relações entre características de pessoas ou grupos [...]" e "Algumas pesquisas de levantamento são empregadas com o propósito de identificar fortes relações entre variáveis." A estratégia de pesquisa utilizada para o presente trabalho pode ser classificada como levantamento.

\subsection{Caracterização da população}

Andrezo e Lima (2007, p. 47) explicam que "[...] a Lei n. 4.595/64 considera que são instituições financeiras os bancos; as sociedades de crédito, financiamento e investimento; as caixas econômicas e as cooperativas de crédito ou a seção de crédito das cooperativas." Para os autores, além dessas, outras entidades devem observar a Lei n. 4.595/64, tais como: as bolsas de valores, companhias de seguros, companhias de capitalização, sociedades que efetuam distribuição de prêmios em imóveis, mercadorias ou dinheiro e pessoas físicas ou jurídicas que efetuam compra e venda de títulos.

Diante do objetivo deste trabalho, pensou-se, inicialmente, que seria ideal estudar os mais diversos tipos de Instituições Financeiras que operam no Brasil, com a finalidade de verificar as suas práticas de Controladoria. Assim, ter-se-ia uma amostra diversificada, com análises por grupos de instituições, refletindo a realidade de uma forma mais completa. Contudo, uma pesquisa dessa dimensão demandaria uma equipe de pesquisadores e um tempo que extrapolaria o limite desta dissertação, devido ao grande número de instituições para analisar respostas de entrevistas e questionários. Por tais motivos, tornou-se necessário delimitar a população de estudo deste trabalho. 
O fato de não se trabalhar com todas as Instituições Financeiras que operam no Brasil não inviabiliza o estudo proposto por esta dissertação. Respaldando tal afirmação, Gil (2002, p. 121) afirma que:

De modo geral, os levantamentos abrangem um universo de elementos tão grande que se torna impossível considerá-los em sua totalidade. Por essa razão, o mais freqüente é trabalhar com uma amostra, ou seja, com uma pequena parte dos elementos que compõem o universo.

Para esta dissertação, o universo de pesquisa delimitado é composto pelos 50 (cinquenta) maiores bancos públicos e privados que operam no Brasil, nacionais e estrangeiros, de acordo com o ranking da edição Melhores e Maiores da Revista Exame, publicada em julho de 2008, com dados relativos a 2007. O critério utilizado pela Revista Exame para a classificação dessas instituições foi o valor do Patrimônio Líquido em 31 de Dezembro de 2007.

A escolha por essas instituições partiu da premissa de que se aplicam boas práticas de governança e, principalmente, as mais completas e complexas práticas de Controladoria dentre as Instituições Financeiras para que possam atender às exigências de seus órgãos reguladores. Além disso, o valor do Patrimônio dessas entidades e o seu valor para a sociedade tornam-se importante alvo de estudos.

A Tabela 6 apresenta a relação dos bancos utilizados para a pesquisa, ordenados pelo valor do Patrimônio Líquido Legal (PL Legal ${ }^{4}$ ). São elencados detalhes, tais como seu Ranking na Revista Exame, Nome Fantasia, Cidade Sede, Patrimônio Líquido Legal, Ativo total e o Controle Acionário.

Tabela 6 - Instituições selecionadas para a pesquisa (valores em US\$ milhões de 31/12/2007)

\begin{tabular}{l|l|l|r|r|l}
\hline Ranking & \multicolumn{1}{|c|}{ Nome Fantasia } & \multicolumn{1}{c|}{ Sede } & \multicolumn{1}{c|}{$\begin{array}{c}\text { PL } \\
\text { Legal }\end{array}$} & \multicolumn{1}{c|}{$\begin{array}{c}\text { Ativo } \\
\text { Total }\end{array}$} & \multicolumn{1}{c}{ Controle } \\
\hline 1 & Bradesco & Osasco & $16.845,9$ & $177.922,9$ & Brasileiro \\
\hline 2 & Banco do Brasil & Brasília & $13.438,9$ & $206.668,6$ & Brasileiro \\
\hline 3 & Itaú & São Paulo & $6.899,4$ & $172.862,9$ & Brasileiro \\
\hline 4 & Unibanco & São Paulo & $6.391,5$ & $89.059,7$ & Brasileiro \\
\hline 5 & Banco Real & São Paulo & $6.327,8$ & $115.515,6$ & Bras.-holandês \\
\hline 6 & Caixa Econômica Federal & Brasília & $5.796,3$ & $140.796,7$ & Brasileiro \\
\hline 7 & Santander & São Paulo & $4.831,8$ & $67.103,6$ & Espanhol \\
\hline 8 & Votorantim & São Paulo & $3.392,6$ & $45.256,4$ & Brasileiro
\end{tabular}

continua

\footnotetext{
${ }^{4}$ É a soma do capital, das reservas, dos lucros acumulados e dos resultados de exercícios futuros, menos a soma do capital a integralizar, das ações em tesouraria e dos prejuízos acumulados, sem considerar os efeitos da inflação. Mede a riqueza da empresa, embora distorcida pela ausência de correção monetária desde 1996.
} 


\begin{tabular}{|c|c|c|c|c|c|}
\hline Ranking & Nome Fantasia & Sede & $\begin{array}{c}\text { PL } \\
\text { Legal }\end{array}$ & $\begin{array}{l}\text { Ativo } \\
\text { Total }\end{array}$ & Controle \\
\hline 9 & Itaú BBA & São Paulo & $3.004,0$ & $55.751,5$ & Brasileiro \\
\hline 10 & HSBC Bank & Curitiba & $2.578,4$ & $40.273,4$ & Inglês \\
\hline 11 & Safra & São Paulo & $2.216,3$ & $40.939,9$ & Brasileiro \\
\hline 12 & UBS Pactual & Rio de Janeiro & $2.154,3$ & $11.367,7$ & Suíço \\
\hline 13 & Citibank & São Paulo & $1.807,3$ & $17.886,3$ & Americano \\
\hline 14 & Banrisul & Porto Alegre & $1.566,3$ & $11.636,0$ & Brasileiro \\
\hline 15 & Nossa Caixa & São Paulo & $1.470,9$ & $26.713,7$ & Brasileiro \\
\hline 16 & Banco da Amazônia & Belém & 945,9 & $3.397,8$ & Brasileiro \\
\hline 17 & BNB & Fortaleza & 901,7 & $7.989,6$ & Brasileiro \\
\hline 18 & Bicbanco & São Paulo & 874,9 & $6.224,2$ & Brasileiro \\
\hline 19 & Daycoval & São Paulo & 863,1 & $3.631,0$ & Brasileiro \\
\hline 20 & Alfa & São Paulo & 800,8 & $7.466,6$ & Brasileiro \\
\hline 21 & Panamericano & São Paulo & 731,3 & $2.972,2$ & Brasileiro \\
\hline 22 & BMG & Belo Horizonte & 729,0 & $3.717,0$ & Brasileiro \\
\hline 23 & JP Morgan & São Paulo & 717,9 & $5.925,6$ & Americano \\
\hline 24 & Société Générale Brasil S.A. & São Paulo & 706,8 & $1.748,5$ & Francês \\
\hline 25 & ABC BRASIL & São Paulo & 615,3 & $3.199,2$ & Bahrain \\
\hline 26 & BBM & Salvador & 562,0 & $10.072,2$ & Brasileiro \\
\hline 27 & Cruzeiro do Sul & São Paulo & 585,5 & $2.433,0$ & Brasileiro \\
\hline 28 & GMAC & São Paulo & 487,8 & $3.315,2$ & Americano \\
\hline 29 & Sofisa & São Paulo & 481,6 & $2.269,8$ & Brasileiro \\
\hline 30 & Pine & São Paulo & 450,4 & $3.220,7$ & Brasileiro \\
\hline 31 & BNP Paribas & São Paulo & 445,2 & $8.741,0$ & Francês \\
\hline 32 & Volkswagen & São Paulo & 430,7 & $3.994,4$ & Alemão \\
\hline 33 & Deutsche Bank & São Paulo & 421,4 & $7.866,9$ & Alemão \\
\hline 34 & Paraná & Curitiba & 423,0 & 858,5 & Brasileiro \\
\hline 35 & $\mathrm{CNH}$ & Curitiba & 410,6 & $2.628,6$ & Italiano \\
\hline 36 & Credicard Citi & São Paulo & 395,0 & $2.810,2$ & Brasileiro \\
\hline 37 & IBI & Barueri & 371,9 & $3.214,1$ & Holandês \\
\hline 38 & Fibra & São Paulo & 304,7 & $8.010,8$ & Brasileiro \\
\hline 39 & Schahin & São Paulo & 281,6 & $1.283,5$ & Brasileiro \\
\hline 40 & ING Bank & São Paulo & 285,0 & $3.474,7$ & Holandês \\
\hline 41 & Morgan Stanley & São Paulo & 281,4 & $1.660,6$ & Americano \\
\hline 42 & Mercantil do Brasil & Belo Horizonte & 263,4 & $3.750,4$ & Brasileiro \\
\hline 43 & $\begin{array}{l}\text { Banco Mercedes-Benz } \\
\text { do Brasil S/A }\end{array}$ & São Paulo & 265,4 & $2.043,9$ & Alemão \\
\hline 44 & Banestes & Vitória & 243,5 & $4.036,5$ & Brasileiro \\
\hline 45 & WestLB & São Paulo & 243,0 & $2.087,5$ & Alemão \\
\hline 46 & Rabobank & São Paulo & 239,9 & $2.800,0$ & Holandês \\
\hline 47 & Rural & Belo Horizonte & 184,1 & $1.154,3$ & Brasileiro \\
\hline 48 & Indusval Multistock & São Paulo & 229,7 & $1.244,0$ & Brasileiro \\
\hline 49 & Barclays & São Paulo & 211,9 & $1.747,4$ & Anglo-Argent. \\
\hline 50 & BRB & Brasília & 191,1 & $2.366,8$ & Brasileiro \\
\hline
\end{tabular}

Fonte: Revista Exame - Ed. Maiores e Melhores - jul./2008

\subsection{Técnicas de coleta de dados}

A coleta de dados está relacionada ao tipo de pesquisa que se pretende realizar. De acordo com Marconi e Lakatos (2005, p. 168), "São vários os procedimentos para realização da 
coleta de dados, que variam de acordo com as circunstâncias ou com o tipo de investigação." Para Martins e Theóphilo (2007, p. 83), os dados são divididos entre primários e secundários:

São denominados primários os dados colhidos diretamente na fonte. Em contraste, os dados secundários são aqueles já coletados que se encontram organizados em arquivos, banco de dados, anuários estatísticos, relatórios etc.

Para atender o objetivo geral desta pesquisa, que é verificar se, e em que medida, as práticas de Controladoria dos cinquenta maiores bancos que operam no Brasil refletem uma Estrutura Conceitual Básica de Controladoria, serão coletados dados primários com a utilização de entrevistas e questionários. Martins (1994, p. 41) defende que "Particularmente, nos estudos exploratórios e estudos descritivos os instrumentos mais comuns para coleta de dados são o questionário e a entrevista."

\subsubsection{Entrevista}

Para Martins (1994, p. 37), a entrevista é definida como “[...] um processo de interação social entre duas pessoas na qual uma delas, o entrevistador, tem por objetivo a obtenção de informações por parte do outro, o entrevistado." A entrevista tem certas vantagens que outros métodos de observação não têm, como, por exemplo, a profundidade, na qual o entrevistador pode sondar as razões das respostas dadas. (KERLINGER, 1980, p. 350).

Apesar das vantagens da ferramenta de entrevista, devido ao tempo limitado para o desenvolvimento da dissertação, torna-se inviável a utilização de entrevista para toda a população deste trabalho. Dessa maneira, optou-se por utilizar a entrevista com 6 (seis) instituições financeiras, que fazem parte dos 8 (oito) maiores bancos da população selecionada. Optou-se por eleger essas instituições para as entrevistas, por representarem um montante de mais de 60\% do Patrimônio Líquido Legal e mais de $70 \%$ dos Ativos totais do somatório total dos 50 (cinquenta) bancos selecionados.

As entrevistas foram realizadas, em sua maioria, pelas pessoas diretamente responsáveis pela área denominada Controladoria (ou que exerce suas funções) dos bancos selecionados. Quando não era possível, algum colaborador com grande experiência, nessa área, era indicado para a entrevista. Os locais utilizados para as entrevistas foram as próprias dependências das 
sedes das instituições, com um tempo médio de 60 (sessenta) minutos de duração. Tais entrevistas foram realizadas no período de novembro de 2008 a abril de 2009.

Essas entrevistas proporcionaram ao pesquisador um conjunto de detalhes que facilitou o entendimento das respostas dos questionários enviados aos demais bancos. Deve-se salientar que para essas entrevistas foi utilizado o mesmo questionário enviado aos outros bancos, que será detalhado na próxima seção.

\subsubsection{Questionário}

Para Kerlinger (1980, p. 350), "Há duas maneiras gerais de obter informações das pessoas. Uma delas é fazendo-lhes perguntas. Esta é bem direta. A segunda maneira é fazendo os indivíduos responderem algum tipo de estímulo estruturado [...]." Dentre as técnicas disponíveis para obter informações das entidades pesquisadas, além da entrevista, optou-se, neste trabalho, pela utilização de questionário.

Gil (2002, p. 115) afirma que "[...] o questionário constitui o meio mais rápido e barato de obtenção de informações, além de não exigir treinamento de pessoal e garantir o anonimato." Para Martins e Theóphilo (2007, p. 90), “O questionário é um importante e popular instrumento de coleta de dados para uma pesquisa social." Além de ser um importante instrumento para coleta de dados, Marconi e Lakatos (2005, p. 203) elencam diversas vantagens na utilização do questionário, tais como: a economia de tempo, a possibilidade de atingir maior número de pessoas simultaneamente e a uniformidade na avaliação. Assim, o questionário viabiliza o tempo disponível e pode ser utilizado como uma ferramenta adequada para a pesquisa.

Martins e Theóphilo (2007, p. 90) informam que o questionário “[...] é encaminhado para potenciais informantes, selecionados previamente [...]." Sendo assim, entrou-se em contato, por telefone, com os outros bancos que não haviam participado das entrevistas, com o intuito de identificar um potencial respondente para o questionário. Procurou-se, inicialmente, o contato com a pessoa diretamente responsável pelo setor de Controladoria da instituição e, quando não era possível, buscou-se encontrar alguém com grande experiência nessa área. 
De posse desses contatos, os questionários foram enviados aos bancos por e-mail, com uma explicação da pesquisa, uma carta de apresentação do orientador (Apêndice 1) e um link para o questionário eletrônico a ser respondido. A coleta desses dados foi realizada entre os meses de março e julho de 2009. Durante esse intervalo, caso o banco não respondesse ao questionário em um mês, um novo e-mail seria enviado questionando se era possível ou não a participação da instituição na pesquisa. Foram realizados, no máximo, quatro contatos com cada instituição, até sua participação ou até o final do período de coleta.

A preparação dos questionários requer um cuidadoso trabalho, para que possam ser eficazes e suas respostas terem validade. Como o questionário é formado, além de questões objetivas, por questões abertas, é de extrema importância atentar-se para a comparabilidade, assim como adverte Demo (2000, p. 29):

Antes de colher o material, é preciso formalizar as perguntas de tal modo que, mesmo sendo abertas, levem ao mesmo contexto de resposta, para que seja viável alguma comparação. Se com cada entrevistado mudamos o contexto da pergunta, teremos casos que não podem ser somados.

O questionário utilizado para esta pesquisa (Anexo I) foi elaborado com base no Capítulo 2 deste trabalho, em que se apresentou a ECBC de Borinelli (2006) juntamente com um estudo das funções e atividades da Controladoria voltadas para bancos. Assim, possibilitou-se elaborar tal questionário que procura verificar a prática da Controladoria em bancos, que tem como foco de investigação, além das funções básicas apresentadas por Borinelli (2006), algumas características específicas voltadas para bancos.

Optou-se por dividir esse questionário em blocos, facilitando o entendimento ao respondente e focando os assuntos em pontos específicos. As próximas seções detalham cada bloco que compõe o questionário.

\subsubsection{Bloco 1 - Identificação}

Esse Bloco tem por objetivo identificar a Instituição que está respondendo ao questionário, com o nome do banco, nome do respondente e o cargo do respondente. É importante salientar que nem sempre o respondente do questionário é o principal responsável pela área de Controladoria do banco. 


\subsubsection{Bloco 2 - Estrutura da instituição}

Conforme colocado pela Perspectiva 3: Aspectos Organizacionais, da ECBC, a Controladoria pode ser considerada um órgão de linha, mas, também, há a possibilidade de atuar como um órgão de staff. Mas nessa Perspectiva, Borinelli (2006, p. 209) enfatiza que "[...] a questão do posicionamento do órgão Controladoria na estrutura organizacional e o grau de autoridade atribuído ao seu gestor dependem de vários fatores."

Com o objetivo de entender a estrutura da instituição e a localização da área de Controladoria (se existir), deixa-se um campo em aberto para que o respondente possa esboçar um organograma da entidade. A orientação é para que o respondente apresente as principais áreas do banco e qual a posição hierárquica da Controladoria nessas áreas. Desse modo, pretende-se entender se a Controladoria está diretamente subordinada à Presidência, conforme determina a ECBC no referencial teórico, ou se o banco está optando por um arranjo diferente. Esse Bloco é um reforço para as respostas dadas nos blocos 3 e 5, para que o pesquisador possa evitar interpretações errôneas a respeito da identificação da unidade organizacional que exerce funções de Controladoria e, até mesmo, das áreas que compõem essa unidade.

\subsubsection{Bloco 3 - Identificação da unidade organizacional que exerce funções de controladoria}

O Bloco 3 é uma continuação do Bloco 2, com detalhes mais extensos acerca da identificação da área de Controladoria no banco. Esse Bloco, também, está relacionado com a Perspectiva 3: Aspectos Organizacionais da ECBC. Conforme Borinelli (2006, p. 192), “[...] a Controladoria, em termos da Perspectiva 3, está sendo entendida como uma área, unidade, divisão ou departamento que faz parte do sistema formal organizacional de uma entidade."

As primeiras perguntas desse Bloco preocupam-se em entender se há ou não uma unidade denominada "Controladoria", seguindo Borinelli (2006, p. 191) enfatizando que "Nesta ECBC, o nome proposto para essa unidade organizacional é Controladoria.” Todavia, existe a preocupação em identificar a área que realiza as funções de Controladoria, mesmo quando essa não é denominada "Controladoria", bem como se essa área de Controladoria é centralizada em um único órgão ou segmentada por produtos e serviços. 


\subsubsection{Bloco 4 - Identificação do profissional da principal unidade de controladoria}

O profissional responsável pela área de Controladoria está estritamente ligado ao posicionamento hierárquico da área, questionado no Bloco 2. Se a área for uma diretoria, provavelmente será um Diretor, se for uma gerência, provavelmente um gerente e assim por diante. Entretanto, há aqui um interesse maior do que simplesmente identificar o cargo do responsável.

Nesse bloco, com cinco questões abertas, procura-se traçar o perfil do profissional responsável pela Controladoria do banco. São questionados dados pessoais como: idade, cursos de graduação e pós-graduação e o tempo que está na função e na empresa. Com isso, além de poder relacionar o cargo do responsável com a posição hierárquica da Controladoria na instituição, torna-se possível traçar um breve perfil curricular do profissional.

\subsubsection{Bloco 5 - Estrutura da controladoria na instituição}

Uma das seções da Perspectiva 3: Aspectos Organizacionais, apresentada por Borinelli (2006, p. 219), é a que trata da organização interna da unidade organizacional Controladoria. O objetivo desse bloco não é entender as funções, mas, apenas, quais seriam as áreas internas dentro da unidade organizacional Controladoria.

Conforme Borinelli (2006, p. 222), “[...] para definir quais áreas internas compõem tal estrutura, considerou-se o rol de funções de Controladoria, apresentado na Perspectiva 2." Neste trabalho, consolidaram-se as funções Perspectiva 2 de Borinelli (2006), com as funções da Controladoria encontradas na literatura para instituições financeiras. Com isso, tornou-se possível construir o Bloco 5 para se verificar quais as unidades internas que compõem a Controladoria nos bancos.

Mas apenas identificar quais as unidades que compõem a área de Controladoria do banco não permite o entendimento das funções e atividades em si da Controladoria. Para tal, é preciso fazer uma verificação separada, com maior profundidade. Por isso, foram criados os próximos Blocos 6 e 7. 


\subsubsection{Bloco 6 - Funções, atribuições e atividades da controladoria}

No Capítulo 2 deste trabalho, foi apresentada a Perspectiva 2: Aspectos Procedimentais da ECBC, estruturada por Borinelli (2006), acrescentada de conceitos apresentados por autores que se preocuparam em estudar a Controladoria para bancos. Dessa maneira, ao final da seção, obteve-se um quadro-resumo (Quadro 2) das funções e atividades da Controladoria para bancos.

Como o bloco verifica as mais diversas funções apresentadas na literatura, optou-se por dividi-las em sub-blocos, organizados pelas seguintes atividades: Contabilidade Societária, Contabilidade Fiscal, Riscos e Controles Internos, Finanças, Sistemas de Informações e Atendimento a Usuários Externos. Também fica disponibilizado ao respondente um campo "Outras", para que se possam elencar funções que não foram abordadas pelo questionário.

Esse quadro-resumo foi a base para elaboração desse Bloco 6, que tem como propósito investigar quais as funções e atividades estão sob a responsabilidade da área de Controladoria e as que não estão, em quais áreas estão alocadas. Essa análise é peça fundamental para atender os objetivos desta pesquisa, já que entender os aspectos procedimentais é de muita importância para verificar a prática da Controladoria nas instituições.

\subsubsection{Bloco 7 - Papel desempenhado pela controladoria em processos específicos}

Em continuidade ao Bloco 6, o Bloco 7 verifica algumas funções específicas da Controladoria em bancos, nas quais dizer simplesmente que estão sob a Controladoria não seria o suficiente para o entendimento da pesquisa. Com isso, o presente bloco abre ao respondente até três opções de respostas para cada função, que são:
A - Não participa do processo
B - Apenas realiza as tarefas da sua área, assim como as demais do banco
C - Fornece apoio/suporte informacional
D - Executa o processo
E - Coordena/organiza o processo
F - É responsável pelo processo
G - É corresponsável pelo processo 
As funções específicas que são verificadas, nesse bloco, estão relacionadas com: planejamento do banco, orçamento, análise de ambiente (concorrente e interno), avaliação de desempenho, custos, planejamento tributário e controle de riscos. Essas funções foram eleitas como específicas por serem objetos de certa contradição na revisão teórica, sendo citadas por alguns autores e omitidas por outros. Torna-se interessante, ainda, entender a intensidade com que a Controladoria participa nesses processos, que, geralmente, aceitam participação de outras áreas da instituição.

\subsubsection{Pré-teste do instrumento}

Antes de iniciar a coleta de dados usando os questionários, utilizou-se, neste trabalho, uma pesquisa piloto. Martins (1994, p. 45) afirma que "Antes da aplicação do instrumento para coleta dos dados (entrevista ou questionário) faz-se necessária a seleção de uma amostra piloto para realização do pré-teste do instrumento."

Em concordância, Gil (2002, p. 119) afirma que a pesquisa-piloto, ou por ele chamada de préteste, é uma etapa importante na coleta de dados. O autor assevera que "Tão logo o questionário, ou o formulário, ou o roteiro da entrevista estejam redigidos, passa-se a seu préteste. Muitos pesquisadores descuidam dessa tarefa, mas somente a partir daí é que tais instrumentos serão validados para o levantamento."

Sendo assim, antes de prosseguir com os questionários definitivos, foram realizadas pesquisas-piloto, com o intuito de verificar se o conteúdo do questionário era fidedigno e capaz de coletar todas as informações necessárias para responder às questões de pesquisa. Essas pesquisas foram realizadas por professores da área de Controladoria e por pessoas ligadas à área de Controladoria de Instituições Financeiras. Com a realização dessas pesquisas-pilotos, pequenos ajustes foram feitos nos questionários. Ressalte-se que as respostas das pesquisas-piloto não fazem parte do resultado da pesquisa.

\subsection{Plano de análise dos resultados}

Após apurar os dados dos questionários devidamente preenchidos, parte-se para uma análise e interpretação desses dados, conforme Martins (1994, p. 47): 
Uma vez depurados, os dados e as informações deverão ser analisados visando à solução do problema de pesquisa proposto, o alcance dos objetivos colimados, bem como utilizados para se testar as hipóteses enunciadas.

Para Marconi e Lakatos (2005, p. 170), análise e interpretação são duas atividades distintas. Para as autoras, "Na análise, o pesquisador entra em maiores detalhes sobre os dados decorrentes do trabalho estatístico, a fim de conseguir respostas às suas indagações, e procura estabelecer as relações necessárias entre os dados obtidos e as hipóteses formuladas." Já a interpretação é definida como "[...] atividade intelectual que procura dar um significado mais amplo às respostas, vinculando-as a outros conhecimentos."

A análise dos dados está relativamente ligada ao instrumental estatístico utilizado. Para Gil (2002, p. 126), “[...] na análise dos dados há necessidade de cálculos estatísticos. Em todos os levantamentos, há que calcular percentagens, médias, correlações etc. Esses procedimentos estão intimamente relacionados com os objetivos da pesquisa." Concorda-se, plenamente, com o autor quanto à importância de um tratamento estatístico para os dados obtidos, que deixam de ser simplesmente dados e passam a ser informações.

Para atender a questão de pesquisa deste trabalho, deve-se analisar a prática da Controladoria nos bancos que responderam aos questionários. Para tal, os dados recebidos foram analisados por meio da estatística descritiva, que permitiu verificar como se distribuem as diversas funções e atribuições da Controladoria nessas instituições. Essa técnica é definida por Martins e Theóphilo (2007, p. 103) da seguinte forma: "Como o próprio nome sugere, a organização, sumarização e descrição de um conjunto de dados é chamada estatística descritiva." Os autores explicam que por intermédio de gráficos, tabelas e cálculo de medidas obtidas, podese compreender o comportamento da variável expressa no conjunto de dados sob análise.

O próximo capítulo tem como objetivo apresentar os resultados obtidos nos bancos utilizados para a pesquisa. Para cada bloco do questionário é realizada uma análise estatística e uma interpretação dos dados obtidos, com a finalidade de atender aos objetivos da pesquisa. 


\section{ANÁLISE DOS RESULTADOS}

Esse capítulo tem como objetivo analisar e interpretar os dados obtidos na pesquisa empírica desta dissertação. Procurou-se organizar os dados coletados com a finalidade de ter informações que permitam alcançar os objetivos especificados.

\subsection{Informações gerais sobre os dados coletados}

Os dados aqui apresentados foram coletados mediante entrevistas e questionários. Das 50 (cinquenta) instituições que, inicialmente, faziam parte da população a ser pesquisada, 6 (seis) informaram no contato inicial que, por motivos de decisões internas da administração, não poderiam participar da pesquisa. Dessa forma, das 44 instituições remanescentes, 6 (seis) foram pesquisadas por meio de entrevistas e 19 instituições responderam ao questionário, totalizando 25 respondentes da pesquisa.

Da população inicial dos 50 maiores bancos que operam no Brasil, 25 deles responderam à pesquisa, ou seja, uma amostra de $50 \%$ da população. Considerando, apenas, as instituições sem restrições quanto à participação na pesquisa, ou seja, 44 bancos, os 25 bancos respondentes equivalem a um retorno de 57\%. A Tabela 7 apresenta um resumo da forma como os dados foram obtidos, os quais serão utilizados para a análise dos resultados nos próximos capítulos.

Tabela 7 - Resumo dos dados obtidos para análise

\begin{tabular}{l|c|c}
\multicolumn{1}{c|}{ Item } & Quantidade & \% \\
\hline Entrevistas realizadas & 6 & $24,00 \%$ \\
\hline Questionários enviados - respondidos & 19 & $76,00 \%$ \\
\hline \hline Total de instituições participantes & 25 & $100,00 \%$ \\
\hline
\end{tabular}

De acordo com a Tabela 7, das 44 instituições que não se recusaram a participar da pesquisa, tem-se um retorno de 6 entrevistas e 19 questionários respondidos, representando $24 \%$ e $76 \%$ do total de respostas, respectivamente. Ressalte-se que, para fins das análises deste trabalho optou-se por não separar os dados obtidos entre entrevistas e questionário, considerando total de 25 respostas como o montante total de participantes. Para Marconi e Lakatos (2005, p. 
203), "Em média, os questionários expedidos pelo pesquisador alcançam $25 \%$ de devolução." Os resultados apresentados do retorno total, se comparado com a média definida por Marconi e Lakatos (2005), é um percentual alto, o que torna a pesquisa viável.

\subsection{Perfil das instituições pesquisadas}

Nesse tópico, são descritas as principais características das instituições financeiras investigadas, para que se possa conhecer o perfil da população pesquisada. Os dados aqui apresentados se referem à população total e às empresas respondentes, sendo coletados com os respondentes, no site das instituições e/ou na Revista Exame - Melhores e Maiores, edição de julho de 2008 .

\subsubsection{Características gerais das instituições}

As instituições financeiras selecionadas para a pesquisa foram apresentadas no Capítulo 3, utilizando-se da publicação dos 50 (cinquenta) maiores bancos da Revista Exame - Melhores e Maiores, edição de julho de 2008, com dados relativos a 2007. Para formar esse ranking, não foram levados em consideração critérios como nacionalidade do capital, número de funcionários ou tipo de organização societária, mas, sim, o Patrimônio Líquido dessas instituições. Dessa forma, as próximas seções encarregam-se de apresentar, brevemente, o perfil desses bancos.

\subsubsection{País acionista controlador}

A Tabela 8, a seguir, apresenta a concentração das instituições pesquisadas e da população como um todo, em relação ao país de origem do acionista controlador. Em alguns casos, dois ou mais países podem ser controladores em conjunto e serão indicados na tabela. 
Tabela 8 - País de origem do acionista controlador

\begin{tabular}{l|c|c|c|c}
\multirow{2}{*}{\multicolumn{1}{c|}{ País }} & \multicolumn{2}{c|}{ Pesquisadas } & \multicolumn{2}{c}{ População } \\
\cline { 2 - 5 } & Freq. & \% & Freq. & \% \\
\hline Brasil & 16 & $64,00 \%$ & 30 & $60,00 \%$ \\
\hline França & 2 & $8,00 \%$ & 2 & $4,00 \%$ \\
\hline Alemanha & 2 & $8,00 \%$ & 4 & $8,00 \%$ \\
\hline Holanda & 2 & $8,00 \%$ & 3 & $6,00 \%$ \\
\hline Brasil-Holanda & 1 & $4,00 \%$ & 1 & $2,00 \%$ \\
\hline Espanha & 1 & $4,00 \%$ & 1 & $2,00 \%$ \\
\hline Estados Unidos & 1 & $4,00 \%$ & 4 & $8,00 \%$ \\
\hline Bahrain & 0 & $0,00 \%$ & 1 & $2,00 \%$ \\
\hline Inglaterra & 0 & $0,00 \%$ & 1 & $2,00 \%$ \\
\hline Inglaterra-Argentina & 0 & $0,00 \%$ & 1 & $2,00 \%$ \\
\hline Itália & 0 & $0,00 \%$ & 1 & $2,00 \%$ \\
\hline Suíça & 0 & $0,00 \%$ & 1 & $2,00 \%$ \\
\hline \hline Total & 25 & $100,00 \%$ & 50 & $100,00 \%$ \\
\hline
\end{tabular}

Observa-se, na Tabela 8, uma grande concentração de controle acionário brasileiro. O Gráfico 3 apresenta a concentração de instituições financeiras pesquisadas em relação ao país de origem do controlador desses bancos pesquisados.

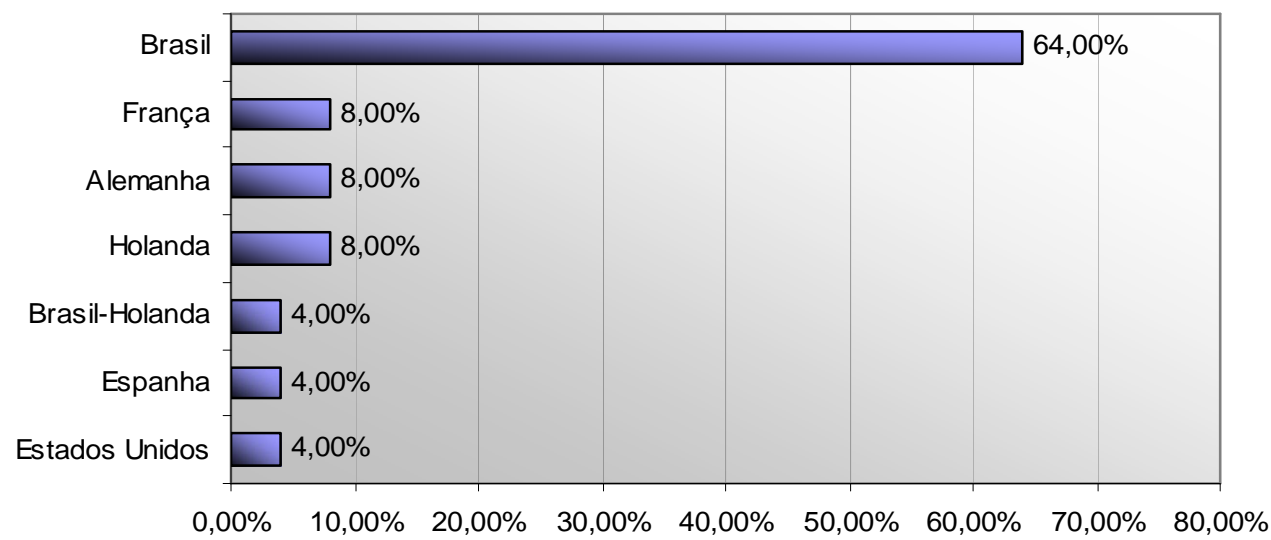

Gráfico 3 - País de origem do acionista controlador

Analisando o Gráfico 3, pode-se observar que Brasil representa a grande maioria dos bancos pesquisados, com $64 \%$ da participação total e, em seguida têm-se França, Alemanha e Holanda com $8 \%$ cada de participação cada país. 


\subsubsection{Controle privado ou estatal}

As instituições financeiras pesquisadas possuem controle estatal ou privado. Nessa seção, demonstra-se, no Gráfico 4, a distribuição da população total entre instituições de controle privado ou estatal.

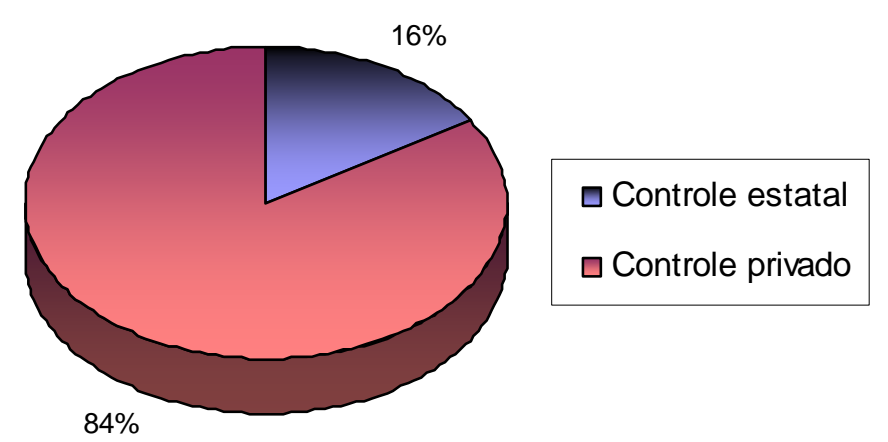

Gráfico 4 - Controle estatal ou privado

O Gráfico 4 mostra que uma grande concentração (mais de 80\%) das instituições financeiras da população está sob o controle privado, enquanto, apenas, $16 \%$ pertencem ao controle estatal.

\subsection{Análise e interpretação das práticas de controladoria nos bancos pesquisados}

Para entender a prática da Controladoria nas instituições financeiras pesquisadas, 0 questionário foi dividido em blocos, com a finalidade de se entender, além das funções e atribuições desempenhadas pela Controladoria, como ela se materializa nessas instituições e informações sobre os responsáveis por essa área. Os tópicos abaixo serão apresentados, detalhadamente, nas próximas seções e estão diretamente relacionados com o questionário (Apêndice 2), exceto o Bloco 2 - Estrutura da Instituição, o qual foi utilizado para entender melhor o posicionamento da Controladoria nos bancos pesquisados:

1. Cargos ocupados pelos respondentes: apresentar informações sobre o colaborador da instituição que respondeu aos questionários ou às entrevistas; 
2. Identificação da unidade organizacional que exerce funções de controladoria: nome, o tipo de divisão, o cargo do responsável e segmentação por produtos ou serviços;

3. Identificação do profissional da principal unidade de controladoria: ano de nascimento, cursos de graduação e pós-graduação e tempo na empresa;

4. Estrutura da controladoria na instituição: identificação da composição da área de Controladoria na entidade;

5. Funções, atribuições e atividades da controladoria: identificar as principais funções desempenhadas pela unidade de Controladoria;

6. Papel desempenhado pela controladoria em processos específicos: identificar o grau de participação da Controladoria em processos específicos de instituições financeiras.

Foi informado aos respondentes da pesquisa, de que não havia obrigatoriedade de resposta para nenhum campo do questionário. Esse procedimento visou preservar a confidencialidade nos aspectos em que fossem necessários aos bancos participantes.

As próximas seções encarregam-se de apresentar uma análise dos resultados obtidos na pesquisa realizada, bem como uma breve interpretação dessas respostas, organizadas pelos blocos estruturados nos questionários.

\subsubsection{Cargos ocupados pelos respondentes}

O Bloco 1 do questionário permite o registro de informações sobre a entrevista, tais como: data, horário e local da realização. Além disso, permite identificar o cargo dos colaboradores da instituição que participaram da pesquisa, respondendo ao questionário ou participando da entrevista. Essa identificação está ilustrada na Tabela 9.

Ressalte-se que, nem sempre, o respondente do questionário ou entrevista era o responsável hierárquico pela unidade organizacional denominada Controladoria ou pela unidade que exerce as funções de Controladoria na instituição. Procurou-se, inicialmente, o contato com o principal responsável, mas a decisão do respondente era uma escolha interna das instituições. A única condição imposta pelo pesquisador era a necessidade de que o entrevistado fosse ligado à área de Controladoria de alguma modo, com bons conhecimentos da forma de organização do banco e da área de Controladoria. 
Tabela 9 - Cargo ocupado pelos respondentes

\begin{tabular}{l|c|c}
\hline \multirow{2}{*}{ Cargo ocupado pelos respondentes } & \multicolumn{2}{c}{ Pesquisadas } \\
\cline { 2 - 3 } & Freq. & \% \\
\hline Gerente de Controladoria & 9 & $36,00 \%$ \\
\hline Superintendente de Controladoria & 4 & $16,00 \%$ \\
\hline Diretor & 2 & $8,00 \%$ \\
\hline Chief Financial Office - CFO & 2 & $8,00 \%$ \\
\hline Analista & 2 & $8,00 \%$ \\
\hline Diretor de Contabilidade & 1 & $4,00 \%$ \\
\hline Supervisor Contábil & 1 & $4,00 \%$ \\
\hline Controller & 1 & $4,00 \%$ \\
\hline Técnico Bancário & 1 & $4,00 \%$ \\
\hline Diretor Executivo & 1 & $4,00 \%$ \\
\hline Diretor de Controladoria & 1 & $4,00 \%$ \\
\hline \hline Total & 25 & $100,00 \%$ \\
\hline
\end{tabular}

O Gráfico 5 ilustra os dados da Tabela 9.

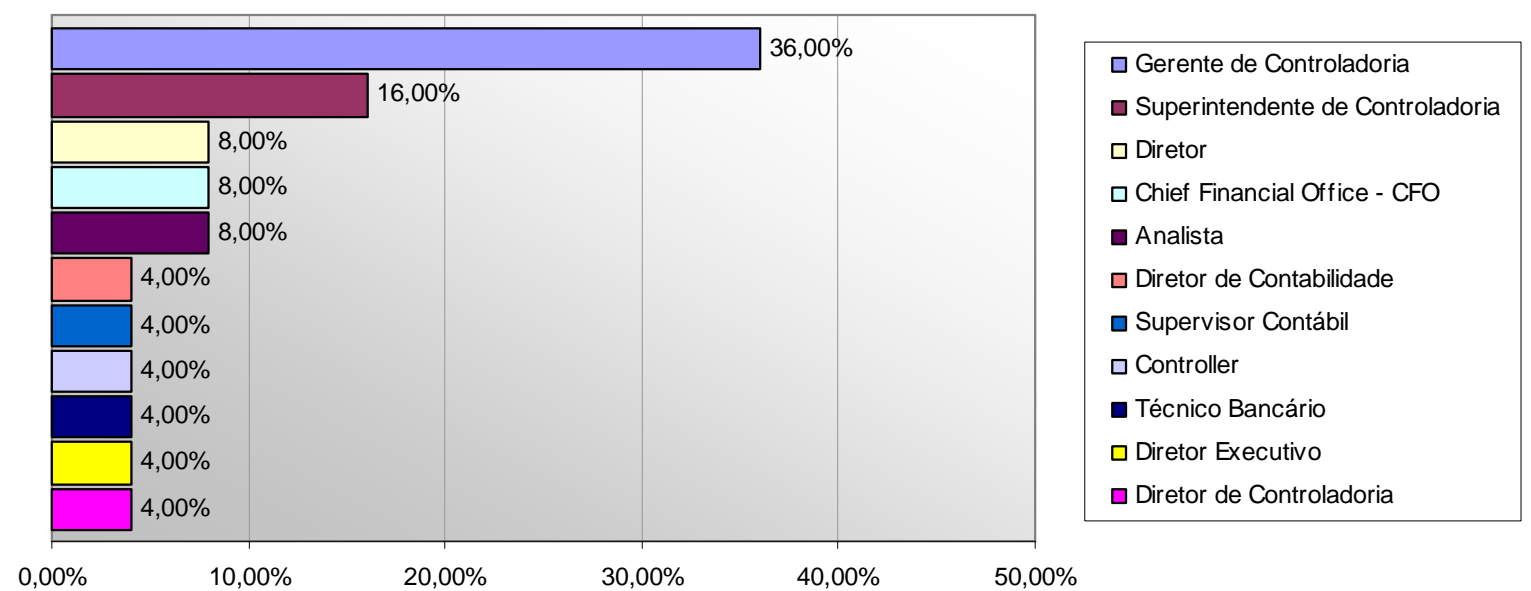

Gráfico 5 - Cargo ocupado pelo respondente

Dos cargos acima, se considerados aqueles com denominações relacionadas especificamente à Controladoria, eles correspondem a mais de $60 \%$ do total. Pode-se entender que, com essa interpretação, os respondentes dos questionários possuem cargos diretamente ligados à área denominada Controladoria. Os demais, provavelmente, têm essa relação, porém a área que exerce as funções de Controladoria pode receber outra denominação, conforme será exposto na próxima seção. 


\subsubsection{Identificação da unidade organizacional que exerce funções de controladoria}

No início do Bloco 3 do questionário, foi perguntado ao respondente se há uma unidade denominada Controladoria na instituição pesquisada. Caso a resposta fosse positiva, procurou-se investigar se havia uma Controladoria Corporativa, Divisional ou algum outro tipo de Controladoria. O Gráfico 6 ilustra a pergunta inicial.

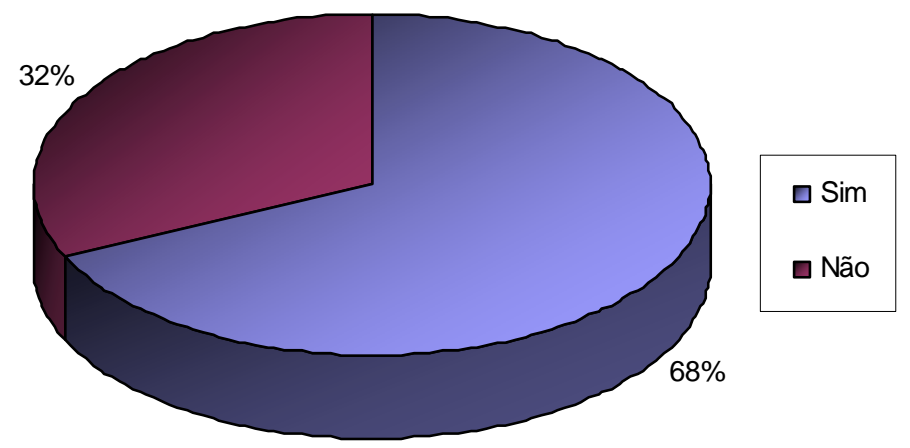

Gráfico 6 - Existência de unidade denominada Controladoria

Dos bancos que participaram da pesquisa, 68\% deles possuem uma área, formalmente, denominada Controladoria. Para esses casos, o gráfico abaixo demonstra se há Controladoria Corporativa, Divisional ou algum outro tipo de Controladoria.

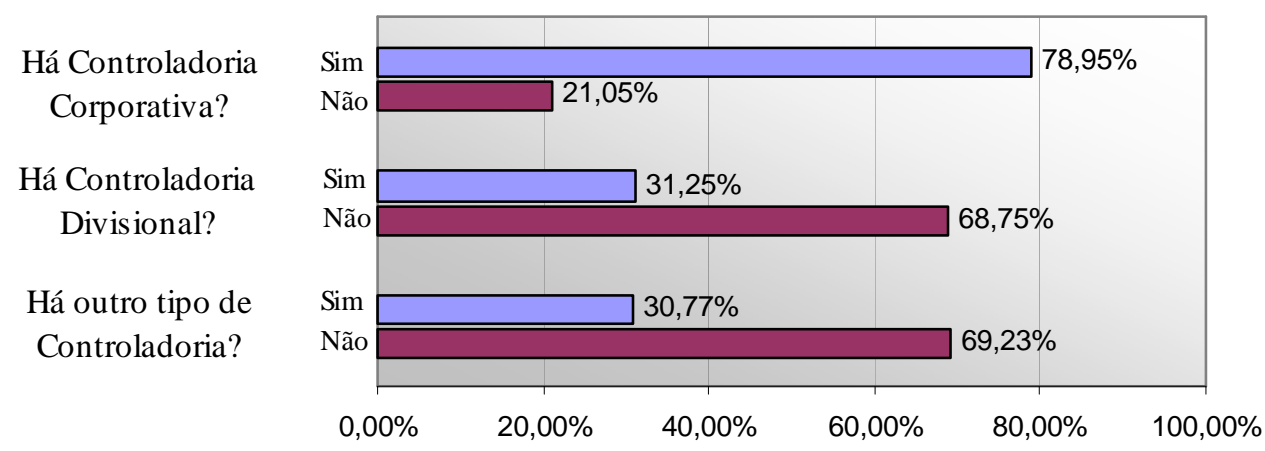

Gráfico 7 - Controladoria corporativa, divisional ou outro tipo

Observe-se, no Gráfico 7, que, das instituições que possuem uma área denominada Controladoria, cerca de $79 \%$ delas possuem Controladoria Corporativa. Enquanto, aproximadamente, $31 \%$ possuem Controladoria Divisional ou algum outro tipo de Controladoria. 
Para os bancos que não possuem uma área constituída, formalmente, com a denominação de Controladoria, procurou-se entender qual a denominação da unidade organizacional que exerce as funções de Controladoria. A Tabela 10 expõe as respostas coletadas.

Tabela 10 - Denominação da unidade que exerce as funções de controladoria

\begin{tabular}{l|c|c} 
Denominação da unidade organizacional & \multicolumn{2}{|c}{ Pesquisadas } \\
\cline { 2 - 3 } que exerce as funções de Controladoria & Freq. & $\%$ \\
\hline Finanças & 4 & $50,00 \%$ \\
\hline Assessoria de Planejamento e Controle & 1 & $12,50 \%$ \\
\hline Contabilidade Geral & 1 & $12,50 \%$ \\
\hline Não há denominação & 1 & $12,50 \%$ \\
\hline Vice Presidência de Controles e Riscos & 1 & $12,50 \%$ \\
\hline \hline Total & 8 & $100,00 \%$ \\
\hline
\end{tabular}

Ressalte-se que o número total dessas empresas representa os 32\%, apresentados no Gráfico 6 das instituições que não possuem uma unidade denominada Controladoria, dentre todas as empresas pesquisadas.

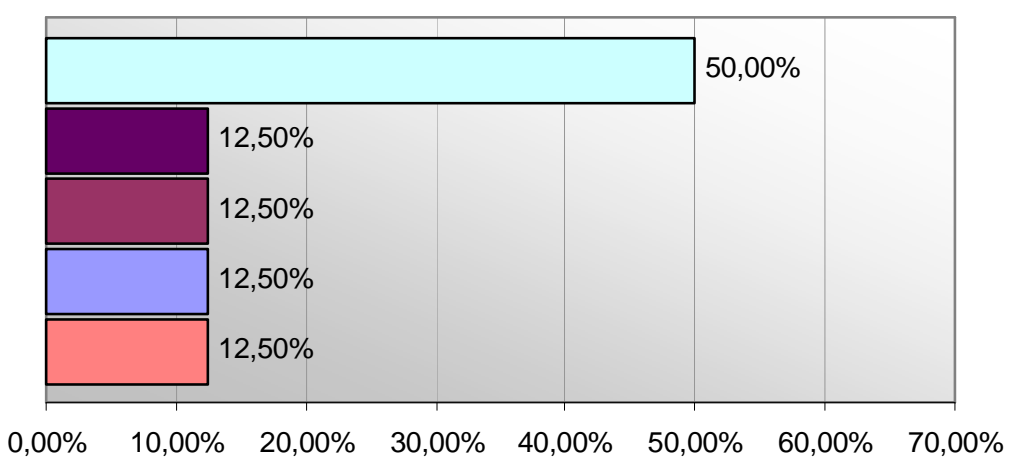

\begin{tabular}{|l|}
$\square$ Finanças \\
$\square$ Assessoria de Planejamento e \\
Controle \\
$\square$ Contabilidade Geral \\
$\square$ Não há denominação \\
$\square$ Vice Presidência de Controles e \\
Riscos
\end{tabular}

Gráfico 8 - Denominação da unidade que exerce as funções de controladoria

Os dados, expostos na Tabela 10 e ilustrados no Gráfico 8, demonstram que $50 \%$ das instituições que não possuem uma área designada Controladoria, utilizam a denominação de "Finanças" para nomear a área que possui as funções e atribuições da Controladoria. O restante distribui-se entre Assessoria de Planejamento e Controle, Contabilidade Geral, VicePresidência de Controles e Riscos e, em uma instituição, não há denominação para a área que exerce funções e atribuições de Controladoria.

Ainda nesse bloco do questionário, dentro da unidade organizacional que exerce funções de Controladoria, seja essa chamada de Controladoria ou não, procurou-se identificar a 
denominação do cargo de seu principal responsável. Com o objetivo de relacionar o cargo do responsável com a unidade que exerce as funções de Controladoria, a Tabela 11 apresenta os cargos elencados pelos respondentes separados em dois grupos: Com Unidade Controladoria, ou seja, com uma unidade, formalmente, denominada Controladoria e Sem Unidade Controladoria, ou seja, sem uma unidade nomeada Controladoria.

Tabela 11 - Cargo do responsável pela unidade organizacional de controladoria

\begin{tabular}{l|c|c|c|c|c|c}
\hline \multirow{2}{*}{$\begin{array}{c}\text { Cargo do responsável pela } \\
\text { unidade organizacional de } \\
\text { Controladoria }\end{array}$} & \multicolumn{2}{c|}{$\begin{array}{c}\text { Com Unidade } \\
\text { Controladoria }\end{array}$} & $\begin{array}{c}\text { Sem Unidade } \\
\text { Controladoria }\end{array}$ & \multicolumn{3}{c}{ Total } \\
\cline { 2 - 7 } & Freq. & $\%$ & Freq. & $\%$ & Freq. & $\%$ \\
\hline Gerente de Controladoria & 6 & $35,29 \%$ & 0 & $0,00 \%$ & 6 & $24,00 \%$ \\
\hline CFO & 1 & $5,88 \%$ & 3 & $37,50 \%$ & 4 & $16,00 \%$ \\
\hline Controller & 4 & $23,53 \%$ & 0 & $0,00 \%$ & 4 & $16,00 \%$ \\
\hline Diretor de Controladoria & 3 & $17,65 \%$ & 0 & $0,00 \%$ & 3 & $12,00 \%$ \\
\hline Diretor Executivo & 1 & $5,88 \%$ & 1 & $12,50 \%$ & 2 & $8,00 \%$ \\
\hline Superintendente & 1 & $5,88 \%$ & 1 & $12,50 \%$ & 2 & $8,00 \%$ \\
\hline Diretor & 1 & $5,88 \%$ & 0 & $0,00 \%$ & 1 & $4,00 \%$ \\
\hline Diretor Financeiro & 0 & $0,00 \%$ & 1 & $12,50 \%$ & 1 & $4,00 \%$ \\
\hline Diretor Gerente & 0 & $0,00 \%$ & 1 & $12,50 \%$ & 1 & $4,00 \%$ \\
\hline Vice Presidente & 0 & $0,00 \%$ & 1 & $12,50 \%$ & 1 & $4,00 \%$ \\
\hline \hline Total & 17 & $100,00 \%$ & 8 & $100,00 \%$ & 25 & $100,00 \%$ \\
\hline
\end{tabular}

Analisando os dados apresentados na Tabela 11, percebe-se que os cargos com denominações relacionadas diretamente à Controladoria, tais como: Gerente de Controladoria, Controller e Diretor de Controladoria, estão presentes, apenas, nas instituições que alegaram ter uma unidade denominada Controladoria.

Os bancos que não possuem uma unidade designada Controladoria apresentam diversas denominações para os cargos dos responsáveis pela unidade que exerce as funções de Controladoria, com destaque para o cargo de CFO, com 37,50\%. Observe-se que, nos dados anteriormente apresentados na Tabela 10, das instituições que não possuíam uma unidade, formalmente, nomeada Controladoria, quatro delas elencaram a área de Finanças como responsável pelas funções de Controladoria. Pode-se, dessa forma, entender que há certa ligação entre os cargos de $\mathrm{CFO}$ e Diretor Financeiro, que também totalizam quatro instituições, com essa área chamada Finanças apontada na tabela anterior.

Outro ponto a se observar é que as respostas da coluna Total, listadas na Tabela 11, mostram uma heterogeneidade dos cargos nas respostas. No entanto, pode-se, supostamente, considerar que os cargos que possuem a denominação Diretor, variam de acordo com o plano e 
nomenclatura dos cargos de cada instituição e, sendo assim, seria possível agrupar os cargos com status de Diretor sem considerar a particularidade das instituições pesquisadas. A Tabela 12 encarrega-se em demonstrar esse agrupamento, não considerando a separação entre instituições com ou sem unidade chamada Controladoria, sugerindo outra forma de interpretação dos dados.

Tabela 12 - Agrupamento do cargo do responsável pela unidade organizacional de controladoria

\begin{tabular}{l|c|c}
\hline \multirow{2}{*}{$\begin{array}{c}\text { Cargo (agrupado) do responsável pela } \\
\text { unidade organizacional de Controladoria }\end{array}$} & \multicolumn{2}{|c}{ Pesquisadas } \\
\cline { 2 - 3 } & Freq. & \% \\
\hline Diretor & 8 & $32,00 \%$ \\
\hline Gerente & 6 & $24,00 \%$ \\
\hline CFO & 4 & $16,00 \%$ \\
\hline Controller & 4 & $16,00 \%$ \\
\hline Superintendente & 2 & $8,00 \%$ \\
\hline Vice Presidente & 1 & $4,00 \%$ \\
\hline \hline Total & 25 & $100,00 \%$ \\
\hline
\end{tabular}

Com essa nova análise, o cargo de Diretor passa a liderar o ranking dos cargos de responsáveis pela unidade organizacional de Controladoria das Instituições. O Gráfico 9 ilustra as respostas encontradas na Tabela 12.

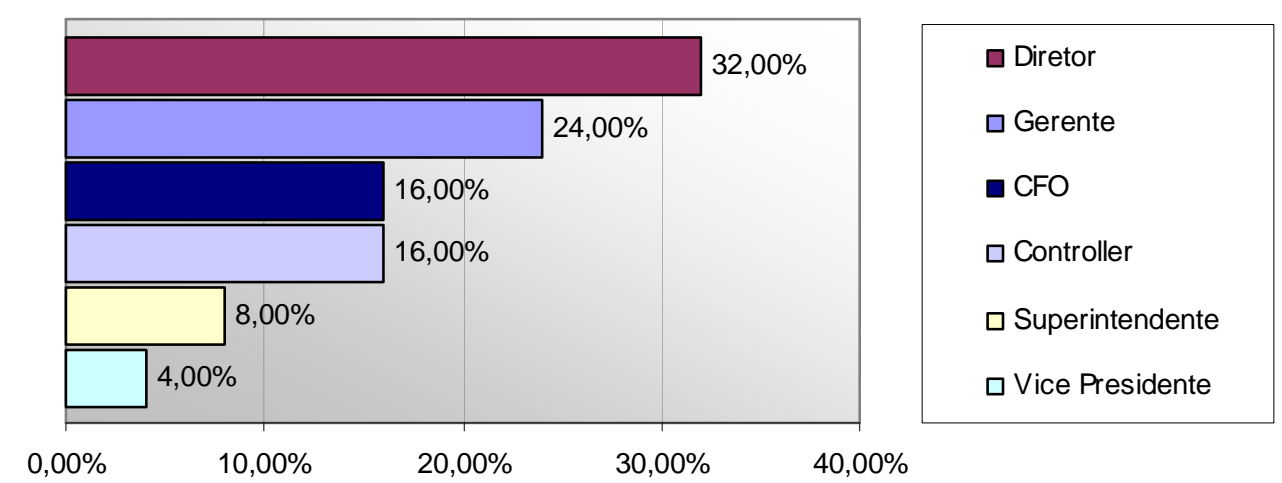

Gráfico 9 - Cargos (agrupados) do responsável pela Controladoria

Não obstante, ainda nesse bloco, perguntou-se se a Controladoria está centralizada em um único órgão. Conforme se pode verificar no Gráfico 10, em mais de $90 \%$ das entidades pesquisadas, a Controladoria é centralizada em um único órgão, sendo esse nomeado Controladoria ou com outra denominação. 


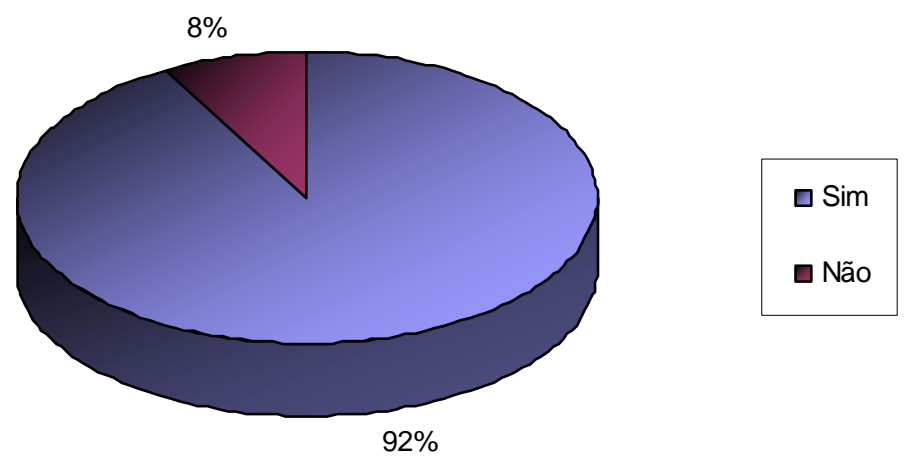

Gráfico 10 - Centralização da controladoria em um único órgão

Para as empresas que responderam não, procurou-se identificar uma provável organização da Controladoria, perguntando-se pela quantidade de órgãos denominados Controladoria que existem na empresa, para verificar o quão descentralizada encontra-se a Controladoria.

Tabela 13 - Quantidade de órgãos denominados controladoria

\begin{tabular}{c|c|c}
\hline \multirow{2}{*}{$\begin{array}{c}\text { Quantos órgãos denominados } \\
\text { Controladoria existem? }\end{array}$} & \multicolumn{2}{|c}{ Pesquisadas } \\
\cline { 2 - 3 } & Freq. & $\%$ \\
\hline 1 & 0 & $0,00 \%$ \\
\hline 2 & 0 & $0,00 \%$ \\
\hline 3 & 0 & $0,00 \%$ \\
\hline 4 & 0 & $0,00 \%$ \\
\hline 5 ou mais & 2 & $100,00 \%$ \\
\hline
\end{tabular}

Com apenas $8 \%$ das instituições pesquisadas apresentando a Controladoria descentralizada e, resumindo-se esse montante em duas instituições, a Tabela 13 mostra que 100\% delas possuem 5 ou mais órgãos denominados Controladoria. Dessa forma, pode-se deduzir que, nesses dois bancos, a Controladoria é totalmente descentralizada, podendo estar constituída em diversas áreas da instituição. Para esses bancos com a Controladoria descentralizada, procurou-se entender se a Controladoria está segmentada por produtos ou serviços do banco. A Tabela 14 apresenta as respostas obtidas.

Tabela 14 - Segmentação da controladoria por produtos ou serviços do banco

\begin{tabular}{c|c|c}
\hline \multirow{2}{*}{$\begin{array}{c}\text { A Controladoria é segmentada por } \\
\text { produtos ou serviços do Banco? }\end{array}$} & \multicolumn{2}{|c}{ Pesquisadas } \\
\cline { 2 - 3 } & Freq. & $\%$ \\
\hline Sim & 2 & $100,00 \%$ \\
\hline Não & 0 & $0,00 \%$ \\
\hline
\end{tabular}


Pode-se verificar, na Tabela 14, que, dos bancos com a Controladoria descentralizada, 100\% deles tem a Controladoria segmentada por produtos ou serviços do Banco, o que justifica a descentralização e a distribuição de unidades de Controladoria em cinco ou mais órgãos.

\subsubsection{Identificação do profissional da principal unidade de Controladoria}

Apesar de não estar diretamente ligado ao objetivo geral proposto neste trabalho, já que a ECBC apresentada por Borinelli (2006) não trata do perfil do profissional da Controladoria, entendeu-se que seria proveitoso apresentar, nesse capítulo, traços gerais do perfil do profissional responsável pela principal unidade de Controladoria, sendo ela denominada Controladoria ou não.

Faz-se necessário observar que a quantidade total de respondentes das questões abaixo pode ser divergente do total de bancos participantes da pesquisa, pois algumas instituições optaram por não fornecer informações sobre o perfil do profissional responsável pela Controladoria, por motivos de confidencialidade.

A Tabela 15 apresenta, nos limites estabelecidos pelo pesquisador, a faixa etária dos profissionais responsáveis pela Controladoria nos bancos pesquisados.

Tabela 15 - Idade do responsável pela controladoria

\begin{tabular}{l|c|c|c}
\multicolumn{2}{c|}{$\begin{array}{c}\text { Idade do responsável pela } \\
\text { Controladoria }\end{array}$} & \multicolumn{3}{c}{ Pesquisadas } \\
\cline { 2 - 4 } & Freq. & $\%$ & $\%$ acum. \\
\hline Até 35 anos & 1 & $4,35 \%$ & $4,35 \%$ \\
\hline 36 a 40 anos & 5 & $21,74 \%$ & $26,09 \%$ \\
\hline 41 a 45 anos & 2 & $8,70 \%$ & $34,78 \%$ \\
\hline 46 a 50 anos & 10 & $43,48 \%$ & $78,26 \%$ \\
\hline Acima de 50 anos & 5 & $21,74 \%$ & $100,00 \%$ \\
\hline \hline Total & 23 & $100,00 \%$ & \\
\hline
\end{tabular}

O Gráfico 11, a seguir, ilustra a distribuição da faixa etária do responsável pela Controladoria, de acordo com os dados da Tabela 15. 


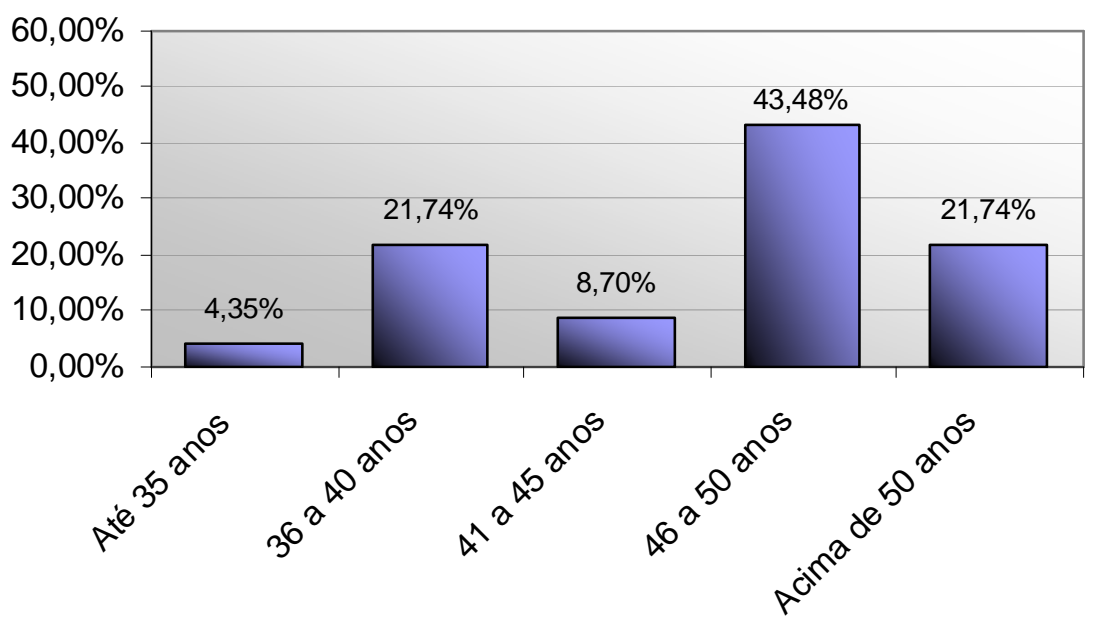

Gráfico 11 - Idade do responsável pela controladoria

Pode-se verificar pelos dados apresentados no Gráfico 11, que o perfil do responsável pela unidade de Controladoria, seja essa denominada Controladoria ou não, encontra-se, em sua maioria (mais de 60\%), na faixa etária acima dos 46 anos. Ressalte-se que a idade média desse profissional do grupo pesquisado é de 46 anos.

Além da idade do responsável pela Controladoria, outra informação procurada para compor o perfil do profissional foi a formação acadêmica. Primeiramente, foi questionado em qual curso de graduação o profissional era formado. A Tabela 16 revela as respostas obtidas.

Tabela 16 - Formação de graduação do responsável pela controlado
\begin{tabular}{l|c|c}
\multicolumn{1}{c}{$\begin{array}{c}\text { Formação de graduação do } \\
\text { responsável pela Controladoria }\end{array}$} & Freq. & $\%$ \\
\cline { 2 - 3 } Contabilidade & 6 & $26,09 \%$ \\
\hline Economia & 5 & $21,74 \%$ \\
\hline Contabilidade e Administração & 4 & $17,39 \%$ \\
\hline Contabilidade e Economia & 3 & $13,04 \%$ \\
\hline Engenharia & 3 & $13,04 \%$ \\
\hline Administração & 2 & $8,70 \%$ \\
\hline \hline Total & 23 & $100,00 \%$ \\
\hline
\end{tabular}

As respostas, apresentadas na Tabela 16, mostram que alguns profissionais possuem mais de um curso de graduação, tal como "Contabilidade e Administração" ou "Contabilidade e Economia". A formação, apenas, em Contabilidade representa, aproximadamente, $26 \%$ do total, mas se considerado Contabilidade entre os cursos de graduação, não como uma formação exclusiva, tem-se um montante de aproximadamente 57\%. Isso evidencia que os 
graduados em Contabilidade são maioria entre os responsáveis pela Controladoria, nas instituições pesquisadas.

Na sequência, foi questionada a formação em pós-graduação dos profissionais responsáveis pela Controladoria nos bancos pesquisados. A Tabela 17 apresenta os dados encontrados.

Tabela 17 - Formação de pós-graduação do responsável pela controladoria

\begin{tabular}{l|c|c}
\multicolumn{1}{c|}{$\begin{array}{c}\text { Formação de pós-graduação do responsável pela } \\
\text { Controladoria }\end{array}$} & \multicolumn{2}{c}{ Pesquisadas } \\
\cline { 2 - 3 } & Freq. & $\%$ \\
\hline Mestrado (Economia, Adm., Contabilidade, Engenharia) & 6 & $26,09 \%$ \\
\hline MBA Finanças & 5 & $21,74 \%$ \\
\hline Não possui & 5 & $21,74 \%$ \\
\hline MBA Controladoria & 3 & $13,04 \%$ \\
\hline Doutorado (Economia, Adm., Contabilidade, Engenharia) & 2 & $8,70 \%$ \\
\hline Especialização em Administração e Controladoria & 1 & $4,35 \%$ \\
\hline MBA Gestão Empresarial, Gestão de Negócios ou Executivo & 1 & $4,35 \%$ \\
\hline \hline Total & 23 & $100,00 \%$ \\
\hline
\end{tabular}

Destaque-se, na tabela acima, uma grande formação de pós-graduação dos profissionais responsáveis pela Controladoria em Mestrado, com, aproximadamente, 26\% dos participantes. Entretanto, se somados, os cursos de MBA liderariam a formação de pós-graduação dos profissionais, com, aproximadamente, 39\%. Pode-se perceber, também, que uma grande parcela desses profissionais, de aproximadamente $22 \%$, não possui curso de pós-graduação.

Procurou-se, também, nesse Bloco, investigar quanto tempo o colaborador responsável pela Controladoria está trabalhando na empresa e nessa função. A Tabela 18 apresenta os dados encontrados nessas questões, organizados por intervalos de anos estruturados pelo pesquisador.

Tabela 18 - Tempo do colaborador responsável pela controladoria na empresa e na função

\begin{tabular}{l|c|c|c|c|c|c}
\multirow{2}{*}{\multicolumn{1}{c}{ Anos }} & \multicolumn{3}{c|}{ Tempo na Empresa } & \multicolumn{3}{c}{ Tempo na Função } \\
\cline { 2 - 7 } & Freq. & \% & \% acum. & Freq. & \% & \% acum. \\
\hline Até 5 anos & 7 & $30,43 \%$ & $30,43 \%$ & 11 & $47,83 \%$ & $47,83 \%$ \\
\hline 6 a 10 anos & 3 & $13,04 \%$ & $43,48 \%$ & 5 & $21,74 \%$ & $69,57 \%$ \\
\hline 11 a 15 anos & 5 & $21,74 \%$ & $65,22 \%$ & 1 & $4,35 \%$ & $73,91 \%$ \\
\hline 16 a 20 anos & 2 & $8,70 \%$ & $73,91 \%$ & 4 & $17,39 \%$ & $91,30 \%$ \\
\hline Mais de 20 anos & 6 & $26,09 \%$ & $100,00 \%$ & 2 & $8,70 \%$ & $100,00 \%$ \\
\hline \hline Total & 23 & $100,00 \%$ & & 23 & $100,00 \%$ & \\
\hline
\end{tabular}


O Gráfico 12 ilustra os dados da Tabela 18, agrupados pelo mesmo intervalo em anos da tabela e divididos entre "Tempo na Empresa" e "Tempo na Função".

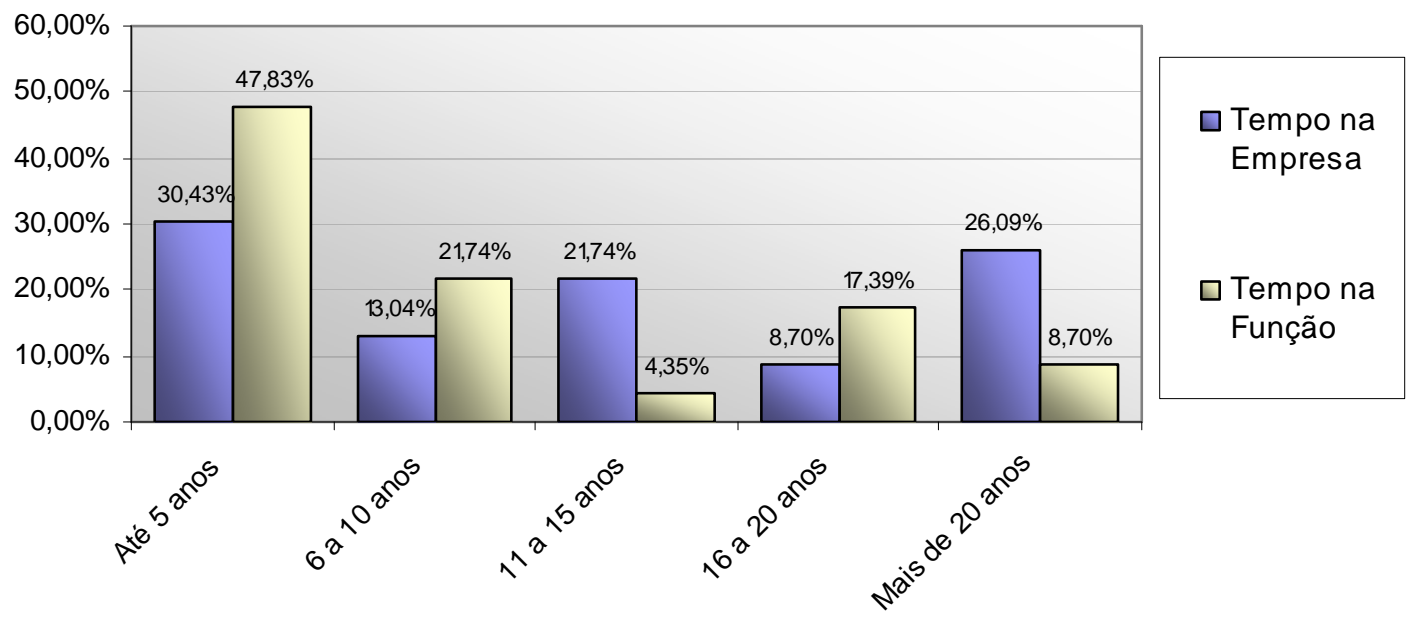

Gráfico 12 - Idade do responsável pela controladoria

A distribuição dos dados nos intervalos de anos, apresentada no Gráfico 12, mostra que, quanto ao tempo de empresa, não há uma concentração em uma única faixa etária, sendo que as maiores concentrações aparecem entre "até 5 anos" e "mais de 20 anos" com 30,43\% e 26,09\%, respectivamente. Desse modo, não há como definir se há um padrão quanto ao tempo de empresa para os responsáveis pela Controladoria, já que os dados se distribuem, quase que uniformemente, por diversas faixas de anos.

Quanto ao tempo na função, ou seja, como responsável pela Controladoria na instituição, percebe-se uma grande concentração nas duas faixas: "até 5 anos" e "6 a 10 anos", com $47,83 \%$ e 21,74\%, respectivamente. Isso demonstra que, na função de responsável pela Controladoria, esses profissionais estão nessa função, geralmente, há menos de 10 anos.

O questionário, também, abordou uma questão, com a finalidade de entender se o profissional responsável foi contratado para a função de responsável pela Controladoria ou se foi transferido de outra área, com livre abertura para explicar qual a área anterior. A Tabela 19, a seguir, lista as respostas fornecidas pelas instituições. 
Tabela 19 - Responsável pela controladoria: contratado ou transferido para a função

\begin{tabular}{l|c|c}
\hline \multirow{2}{*}{$\begin{array}{c}\text { Colaborador Responsável pela Controladoria: } \\
\text { Contratado ou Transferido }\end{array}$} & \multicolumn{2}{c}{ Pesquisadas } \\
\cline { 2 - 3 } & Freq. & $\%$ \\
\hline Contratado para essa função & 14 & $60,87 \%$ \\
\hline Transferido da área de Finanças/Tesouraria/Riscos & 3 & $13,04 \%$ \\
\hline Transferido de outra área & 3 & $13,04 \%$ \\
\hline Transferido da área de Planejamento & 1 & $4,35 \%$ \\
\hline Transferido da Auditoria & 1 & $4,35 \%$ \\
\hline Transferido da Contabilidade & 1 & $4,35 \%$ \\
\hline \hline Total & 23 & $100,00 \%$ \\
\hline
\end{tabular}

A Tabela 19 comprova que, em mais de $60 \%$ das instituições respondentes, o profissional responsável pela Controladoria foi contratado, especificamente, para essa função e, em alguns casos, transferidos de outras áreas, com destaque para as áreas de Finanças/Tesouraria/Riscos.

\subsubsection{Estrutura da controladoria na instituição}

Para entender o organograma da área denominada Controladoria, ou que exerce suas funções e atribuições, o Bloco 5 do questionário (Apêndice 2) procurou verificar quais as unidades se encontravam, formalmente, constituídas dentro do organograma da Controladoria.

Saliente-se que foram elencadas alternativas objetivas para as respostas, mas havia um campo em aberto para incluir o nome de unidades que não estavam listadas na questão. Para melhorar a qualidade das respostas dessa seção, além de verificar o que foi respondido no Bloco 5, também, foram consultadas as respostas do Bloco 2 do questionário que, quando respondido, fornecia um breve organograma do banco, principalmente no que tange à área de Controladoria. As respostas encontram-se na Tabela 20, a seguir. 
Tabela 20 - Unidades formalmente constituídas na controladoria

\begin{tabular}{l|c|c}
\multirow{2}{*}{ Nome da Unidade } & \multicolumn{2}{c}{ Pesquisadas } \\
\cline { 2 - 3 } & Freq. & $\%$ \\
\hline Contabilidade Gerencial & 22 & $88,00 \%$ \\
\hline Contabilidade Societária & 19 & $76,00 \%$ \\
\hline Contabilidade Fiscal & 18 & $72,00 \%$ \\
\hline Contabilidade Tributária & 18 & $72,00 \%$ \\
\hline Contabilidade de Custos & 17 & $68,00 \%$ \\
\hline Contabilidade Financeira & 17 & $68,00 \%$ \\
\hline Orçamento Empresarial & 16 & $64,00 \%$ \\
\hline Planejamento Tributário & 12 & $48,00 \%$ \\
\hline Contas a Pagar & 11 & $44,00 \%$ \\
\hline Controle Patrimonial & 11 & $44,00 \%$ \\
\hline Controles Internos & 10 & $40,00 \%$ \\
\hline Sistemas de Informações (TI) & 10 & $40,00 \%$ \\
\hline Planejamento Empresarial & 8 & $32,00 \%$ \\
\hline Relações com Investidores & 7 & $28,00 \%$ \\
\hline Auditoria Interna & 3 & $12,00 \%$ \\
\hline Recursos Humanos & 3 & $12,00 \%$ \\
\hline Auditoria Contábil & 2 & $8,00 \%$ \\
\hline Contas a Receber & 2 & $8,00 \%$ \\
\hline Crédito e Cobrança & 2 & $8,00 \%$ \\
\hline Tecnologia da Informação & 2 & $8,00 \%$ \\
\hline Tesouraria & &
\end{tabular}

Os dados, apresentados na Tabela 20, mostram que as áreas relacionadas à Contabilidade estão, formalmente, constituídas sob a Controladoria. A área Contabilidade Gerencial aparece em, aproximadamente, $88 \%$ das instituições pesquisadas. As áreas de Contabilidade Societária, Fiscal e Tributária estão presentes em mais de 70\% dessas instituições.

As respostas que constam da Tabela 20 podem ter alguma relação com a próxima seção, sobre as funções, atribuições e atividades da Controladoria na instituição. Todavia, deve-se atentar para o fato de que algumas das funções ou atividades podem estar sob a responsabilidade da área de Controladoria e não ter uma unidade, formalmente, constituída.

Além das respostas objetivas que já constavam do questionário, o respondente tinha, ainda, a opção de um campo aberto para relacionar outras unidades, formalmente, constituídas na Controladoria. A Tabela 21, a seguir, é um complemento à Tabela 20, tratando-se das respostas que foram inseridas pelos respondentes nesse campo. 
Tabela 21 - Outras unidades formalmente constituídas na controladoria

\begin{tabular}{l|c|c}
\multirow{2}{*}{\multicolumn{1}{c}{ Outras áreas }} & \multicolumn{2}{c}{ Pesquisadas } \\
\cline { 2 - 3 } & Freq. & $\%$ \\
\hline Compliance & 2 & $8,70 \%$ \\
\hline Riscos & 1 & $4,35 \%$ \\
\hline Controle dos Resultados Econômicos & 1 & $4,35 \%$ \\
\hline Projetos & 1 & $4,35 \%$ \\
\hline
\end{tabular}

Percebe-se que Compliance se enquadraria na tabela anterior como Controles Internos, o que elevaria o percentual dessa unidade constituída na Controladoria, dentro das entidades pesquisadas. As outras áreas: Riscos, Controle dos Resultados Econômicos e Projetos, foram encontradas em, apenas, uma instituição, não necessariamente na mesma.

\subsubsection{Funções, atribuições e atividades da Controladoria}

Um dos tópicos do Capítulo 2 deste trabalho foi uma apresentação da ECBC estruturada por Borinelli (2006). A Perspectiva 2 dessa ECBC foi o principal foco de análise, pois, nessa perspectiva, foram discutidas as funções e atividades da Controladoria em entidades gerais. Há ainda, nesse capítulo, uma seção tratando as funções e atividades da Controladoria para instituições financeiras, como uma forma de complementar a Perspectiva 2 da ECBC para uma pesquisa focada em bancos.

Com base nessas funções e atribuições, tanto as da Perspectiva 2 da ECBC, quanto nas discutidas com foco em bancos, foram estruturadas as questões do Bloco 6 do questionário com o objetivo de se entender quais as funções e atribuições estão sob a responsabilidade da Controladoria nos bancos. Para cada atividade questionada, o respondente tinha a opção de responder "Sim", caso a atividade fosse de responsabilidade da Controladoria, ou "Não", com um campo para indicar a área responsável pela atividade. É importante destacar que, quando uma área diferente da Controladoria foi indicada como responsável pela atividade, essa área foi considerada como uma área separada, não sendo uma unidade, formalmente, constituída na Controladoria.

De acordo com a linha apresentada na Perspectiva 2 da ECBC e adotada por este trabalho, cada função da Controladoria é formada por um conjunto de atividades. Assim, para que se possam alcançar os objetivos deste estudo, realizando uma análise de acordo com a ECBC (Perspectiva 2), dividiu-se o bloco em grupos, de acordo com as funções gerais da 
Controladoria: Contabilidade Societária, Contabilidade Fiscal, Riscos e Controles Internos, Finanças, Sistemas de Informações e Atendimento a Usuários Externos. É importante ressaltar que, quando se verifica a aderência da prática da Controladoria dos bancos com a ECBC (Perspectiva 2) nessa seção, entende-se que já está sendo considerado o complemento da revisão das funções da Controladoria para bancos.

Para cada uma dessas funções, apresenta-se uma tabela com as atividades que compõem a função, bem como a área responsável por cada atividade. A última linha da tabela representa o percentual médio de responsabilidade, de cada área apresentada, na função como um todo.

A primeira função pesquisada, a de Contabilidade Societária, tem seus resultados apresentados na Tabela 22. A primeira coluna apresenta a Controladoria como responsável pela atividade. As demais são áreas que foram listadas e denominadas pelos respondentes como as responsáveis pelas atividades e encontram-se separadas da Controladoria.

Tabela 22 - Atividades da função contabilidade societária

\begin{tabular}{l|c|c|c|c}
\hline \multirow{2}{*}{ Função: Contabilidade Societária } & \multicolumn{3}{c}{ Área Responsável } \\
\cline { 2 - 5 } & Controladoria & Contabilidade & Contadoria & RI \\
\hline Atividades: & & & & \\
\hline Controle do plano de contas da instituição & $76,00 \%$ & $20,00 \%$ & $4,00 \%$ & $0,00 \%$ \\
\hline Definição de políticas contábeis & $76,00 \%$ & $20,00 \%$ & $4,00 \%$ & $0,00 \%$ \\
\hline Consolidação das Demonstrações Contábeis & $76,00 \%$ & $20,00 \%$ & $4,00 \%$ & $0,00 \%$ \\
\hline Preparação das Demonstrações Contábeis & $76,00 \%$ & $20,00 \%$ & $4,00 \%$ & $0,00 \%$ \\
\hline Divulgação das informações Contábeis & $72,00 \%$ & $20,00 \%$ & $4,00 \%$ & $4,00 \%$ \\
\hline \hline \% Médio na Função & $75,20 \%$ & $20,00 \%$ & $4,00 \%$ & $0,80 \%$ \\
\hline
\end{tabular}

O que se percebe, na Tabela 22, é que, na maioria das instituições pesquisadas, as atividades da função de Contabilidade Societária são desenvolvidas na área de Controladoria. A área de Contabilidade é a segunda maior área responsável pelas atividades da função de Contabilidade Societária dos bancos pesquisados.

O Gráfico 13, a seguir, agrupa os percentuais apresentados pela Tabela 22 das atividades da função de Contabilidade Societária, mostrando qual a responsabilidade de cada área pela função Contabilidade Societária, em média. 


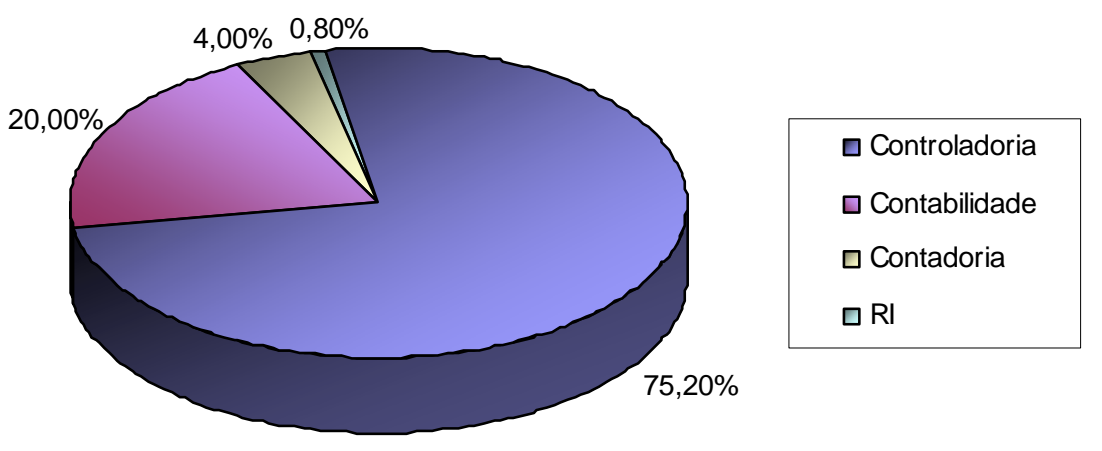

Gráfico 13 - Função contabilidade societária por área

De acordo com o Gráfico 13, em média, a Controladoria é responsável por 75,20\% pela função Contabilidade Societária como um todo. Em segundo lugar fica a área de Contabilidade, com uma média de $20 \%$ das atividades dessa função.

A respeito da relação dos achados nessa função com a ECBC (Perspectiva 2), pode-se dizer que a função Contabilidade Societária, contida na ECBC, está refletida na maioria das instituições pesquisadas, uma vez que os percentuais demonstraram que as atividades desempenhadas, nessa função, estão sob a responsabilidade da unidade de Controladoria.

O segundo bloco procurou verificar a função Contabilidade Fiscal na área de Controladoria dos bancos. A Tabela 23 mostra a função Contabilidade Fiscal, elencando suas respectivas atividades.

Tabela 23 - Atividades da função contabilidade fiscal

\begin{tabular}{l|c|c|c|c|c|c}
\multirow{2}{*}{$\begin{array}{c}\text { Função: } \\
\text { Contabilidade Fiscal }\end{array}$} & \multicolumn{5}{c}{ Área responsável pela atividade } \\
\cline { 2 - 7 } & Controladoria & Contabilidade & $\begin{array}{c}\text { Plan./Gestão } \\
\text { Tribut. }\end{array}$ & Contadoria & Jurídico & Outras \\
\hline Atividades: & & & & & & \\
\hline $\begin{array}{l}\text { Apuração, conferência e } \\
\text { recolhimento de impostos }\end{array}$ & $72,00 \%$ & $16,00 \%$ & $8,00 \%$ & $4,00 \%$ & $0,00 \%$ & $0,00 \%$ \\
\hline Planejamento tributário & $60,00 \%$ & $16,00 \%$ & $12,00 \%$ & $4,00 \%$ & $4,00 \%$ & $4,00 \%$ \\
\hline Gestão e controle de impostos & $72,00 \%$ & $16,00 \%$ & $8,00 \%$ & $4,00 \%$ & $0,00 \%$ & $0,00 \%$ \\
\hline \hline \% Médio na função & $68,00 \%$ & $16,00 \%$ & $9,33 \%$ & $4,00 \%$ & $1,33 \%$ & $1,33 \%$ \\
\hline
\end{tabular}

Assim, como para a função Contabilidade Societária, as atividades relacionadas à Contabilidade Fiscal estão, em sua maioria, sob a responsabilidade da área de Controladoria. Quando a atividade não é desenvolvida na Controladoria, ela se distribui entre diversas outras áreas, mas, predominantemente, na Contabilidade e, em alguns casos, na área denominada 
Planejamento/Gestão Tributária, tendo como destaque a atividade Planejamento Tributário, com $12 \%$ do seu montante total.

O Gráfico 14 ilustra a responsabilidade de cada área elencada pelos respondentes, pela função Contabilidade Fiscal como um todo. Os percentuais apresentados são uma média do total das atividades por área.

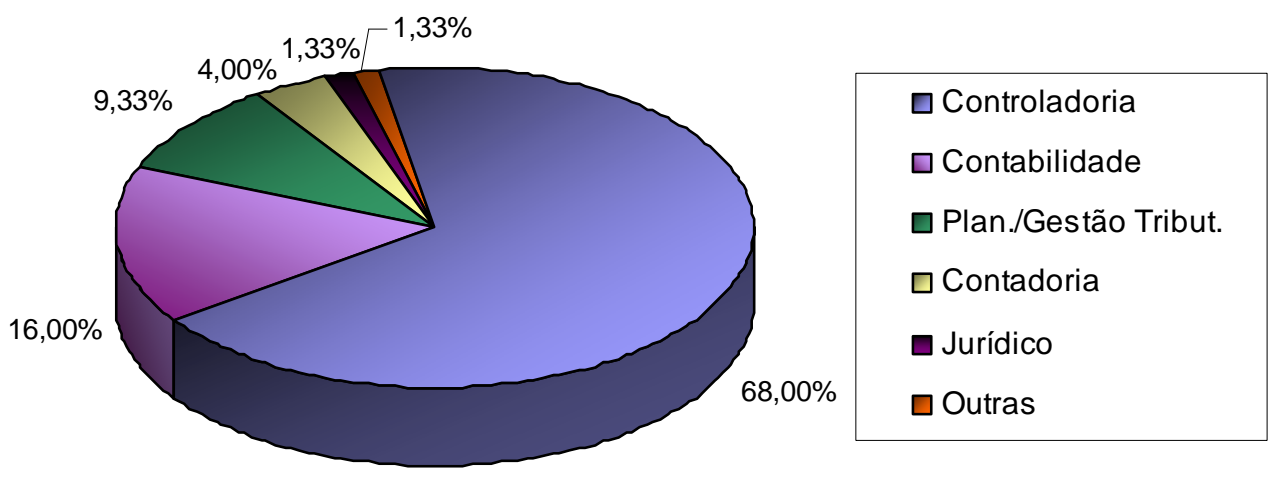

Gráfico 14 - Função contabilidade fisscal por área

Pelo Gráfico 14 é possível perceber que, na função Contabilidade Fiscal como um todo, a Controladoria é responsável por quase $70 \%$ das atividades que compõem essa função. Outras áreas que se destacam, nessa função, são Contabilidade e Planejamento/Gestão Tributária, com $16 \%$ e $9,33 \%$, respectivamente.

Em consonância com a função de Contabilidade Societária, a função de Contabilidade Fiscal constante da ECBC está refletida na maioria das instituições pesquisadas, conforme se verificou na tabela e no gráfico acima.

A próxima função analisada foi a de Riscos e Controles Internos. Essa função teve um agrupamento de diversas atividades, mas, resumidamente, focadas em: auditoria interna, controles internos, gestão de riscos e acompanhamento de Basileia. A Tabela 24, a seguir, apresenta a distribuição das atividades desse grupo entre a Controladoria e demais áreas. 
Tabela 24 - Atividades da função riscos e controles internos

\begin{tabular}{l|c|c|c|c|c|c}
\hline \multirow{2}{*}{$\begin{array}{c}\text { Função: Riscos e Controles } \\
\text { Internos }\end{array}$} & \multicolumn{5}{c}{ Área responsável pela atividade } \\
\cline { 2 - 7 } & Controladoria & Riscos & $\begin{array}{c}\text { Auditoria } \\
\text { Interna }\end{array}$ & $\begin{array}{c}\text { Contr. Int. } \\
\text { /Compliance }\end{array}$ & Tesouraria & Outras \\
\hline Atividades: & $4,00 \%$ & $4,00 \%$ & $84,00 \%$ & $0,00 \%$ & $0,00 \%$ & $8,00 \%$ \\
\hline Auditoria interna & $28,00 \%$ & $\begin{array}{c}20,00 \\
\%\end{array}$ & $4,00 \%$ & $32,00 \%$ & $0,00 \%$ & $16,00 \%$ \\
\hline $\begin{array}{l}\text { Implantação e gestão dos } \\
\text { controles internos do banco }\end{array}$ & $40,00 \%$ & $\begin{array}{c}56,00 \\
\%\end{array}$ & $0,00 \%$ & $0,00 \%$ & $0,00 \%$ & $4,00 \%$ \\
\hline Gestão dos riscos de mercado & $36,00 \%$ & $\begin{array}{c}52,00 \\
\%\end{array}$ & $0,00 \%$ & $0,00 \%$ & $8,00 \%$ & $4,00 \%$ \\
\hline Gestão dos riscos de liquidez & $20,00 \%$ & $\begin{array}{c}64,00 \\
\%\end{array}$ & $0,00 \%$ & $0,00 \%$ & $0,00 \%$ & $16,00 \%$ \\
\hline Gestão dos riscos de crédito & $20,00 \%$ & $\begin{array}{c}60,00 \\
\%\end{array}$ & $0,00 \%$ & $8,00 \%$ & $0,00 \%$ & $12,00 \%$ \\
\hline Gestão dos riscos operacionais & $76,00 \%$ & $\begin{array}{c}20,00 \\
\%\end{array}$ & $0,00 \%$ & $0,00 \%$ & $0,00 \%$ & $4,00 \%$ \\
\hline Acompanhamento da Basileia & $32,00 \%$ & $\begin{array}{c}39,43 \\
\%\end{array}$ & $12,57 \%$ & $5,71 \%$ & $1,14 \%$ & $9,14 \%$ \\
\hline \hline \% Médio na função & & & & & & \\
\hline
\end{tabular}

Como se pode notar na Tabela 24, a Controladoria e a área de Riscos somam um grande montante pela responsabilidade das atividades listadas, relacionadas à função Riscos e Controles Internos. Nesse grupo, a Controladoria destaca-se, apenas, na atividade elencada como "Acompanhamento da Basileia", com 76\% do total. Já a área denominada como Riscos, destaca-se nas atividades de Gestão de Riscos, tanto de Mercado, quanto de Liquidez, Crédito e Operacionais, com participações maiores que $50 \%$ em cada.

Outro destaque na Tabela 24 é a atividade de Auditoria Interna, que está concentrada em sua grande maioria na área denominada Auditoria Interna, com $84 \%$ da atividade. Já a atividade de implantação e gestão dos controles internos é dividida de uma forma muito heterogênea entre Controladoria, Controles Internos/Compliance e Riscos, com 28\%, $32 \%$ e 20\%, respectivamente.

O Gráfico 15, a seguir, permite entender melhor a distribuição da função Riscos e Controles Internos, em média, pelas áreas citadas pelos respondentes. 

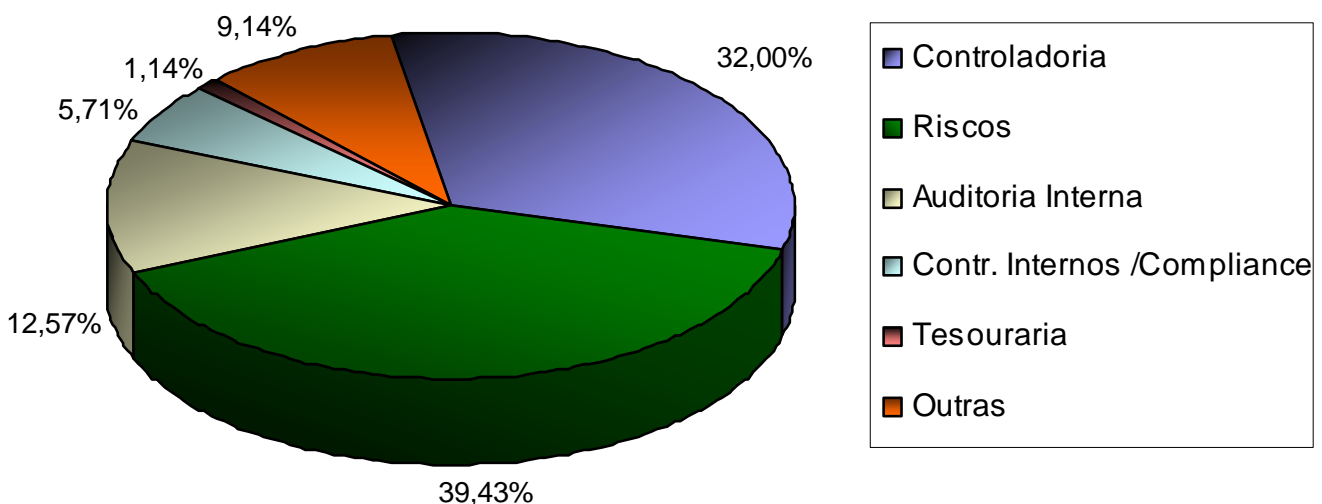

$39,43 \%$

Gráfico 15 - Função riscos e controles internos por área

Do total de atividades da função Riscos e Controles Internos, a área denominada Riscos exerce o maior montante da função, com 39,43\% do total. Na sequência, tem-se a Controladoria, abrangendo $32 \%$ do total. Pode-se perceber que, para essa função, a Controladoria não é a principal responsável, dividindo sua responsabilidade com a área de Riscos, entre outras áreas.

Verifica-se que a ECBC (Perspectiva 2) considerou a função Controle de Riscos e Controles Internos, como sendo de responsabilidade da Controladoria. Outras revisões da literatura, voltada para o estudo da Controladoria em bancos, também, revelaram que os autores indicam que o Controle de Riscos e Controles Internos é uma função típica da Controladoria. Contudo, o que se percebeu, na prática, a função de Controle de Riscos e Controles Internos não é uma função típica da Controladoria. A Tabela 24 evidencia que as atividades relacionadas ao Controle e Gestão de Riscos estão, em mais de 50\% das respostas, sob a responsabilidade da área de Riscos. Outras atividades, tais como Auditoria Interna e Controles internos, também, não estão sob a responsabilidade da Controladoria, portanto, não procedendo às recomendações da ECBC.

$\mathrm{Na}$ sequência, a função de finanças foi investigada. A Tabela 25, a seguir, apresenta as respostas obtidas para as atividades que compõem essa função. 
Tabela 25 - Atividades da função finanças

\begin{tabular}{l|c|c|c|c|c|c|c}
\hline \multirow{2}{*}{ Função: Finanças } & \multicolumn{7}{|c}{ Área responsável pela atividade } \\
\cline { 2 - 8 } & Controladoria & Tesouraria & Financeiro & Contabilidade & RI & Riscos & Outras \\
\hline Atividades: & & & & & & & \\
\hline $\begin{array}{l}\text { Gestão financeira e de } \\
\text { tesouraria }\end{array}$ & $12,00 \%$ & $60,00 \%$ & $16,00 \%$ & $0,00 \%$ & $0,00 \%$ & $4,00 \%$ & $8,00 \%$ \\
\hline Controle fluxo de caixa & $4,00 \%$ & $64,00 \%$ & $12,00 \%$ & $0,00 \%$ & $0,00 \%$ & $4,00 \%$ & $16,00 \%$ \\
\hline $\begin{array}{l}\text { Análise dos índices do } \\
\text { balanço }\end{array}$ & $68,00 \%$ & $0,00 \%$ & $4,00 \%$ & $8,00 \%$ & $4,00 \%$ & $0,00 \%$ & $16,00 \%$ \\
\hline $\begin{array}{l}\text { Análise dos índices dos } \\
\text { concorrentes }\end{array}$ & $60,00 \%$ & $0,00 \%$ & $4,00 \%$ & $4,00 \%$ & $8,00 \%$ & $0,00 \%$ & $24,00 \%$ \\
\hline \hline \% Médio na função & $36,00 \%$ & $31,00 \%$ & $9,00 \%$ & $3,00 \%$ & $3,00 \%$ & $2,00 \%$ & $16,00 \%$ \\
\hline
\end{tabular}

Os resultados que constam da Tabela 25 demonstram que a área Tesouraria, sendo essa separada da Controladoria, é a maior responsável pelas atividades de Gestão Financeira e de Tesouraria e Controle do Fluxo de Caixa, com 60\% e 64\%, respectivamente. Já as atividades de Análise dos Índices do Balanço e Análise dos Índices dos Concorrentes estão, em sua grande parte, concentradas na Controladoria.

O Gráfico 16 demonstra que a Controladoria e a Tesouraria assumem como as duas principais áreas pela função de Finanças nos bancos pesquisados, com o percentual médio das atividades como um todo.

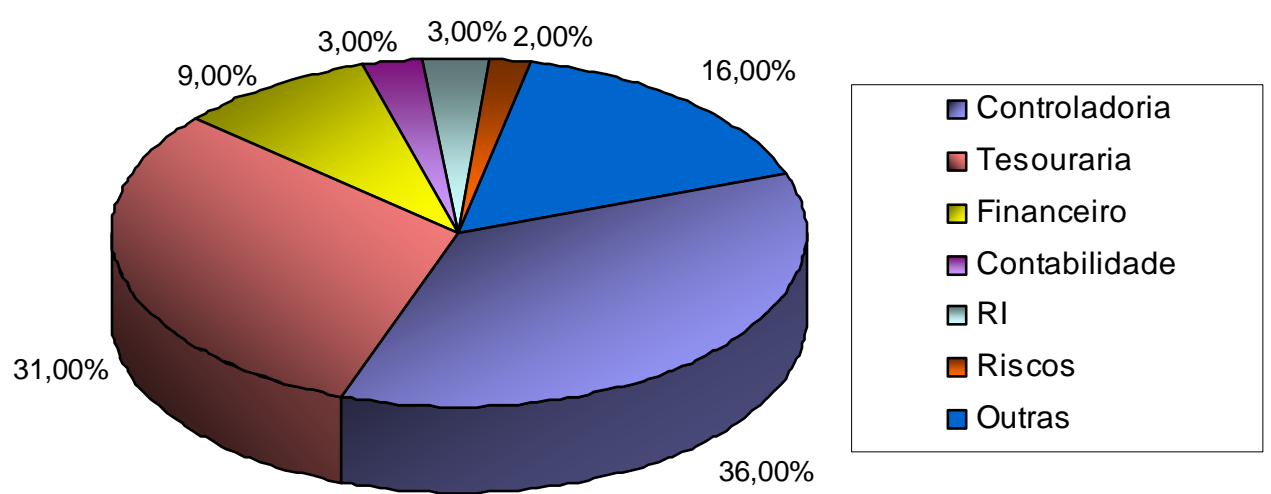

\section{Gráfico 16 - Função finanças}

Pode-se concluir, pelo Gráfico 16, que a Controladoria e a Tesouraria, sendo consideradas áreas distintas, concentram as maiores fatias das atividades da função de Finanças. A área classificada "Outras" abrange respostas diversas, com denominações divergentes das demais e que foram agrupadas para facilitar o entendimento. 
A ECBC considera, relacionadas a outras funções da Controladoria, atividades como de Tesouraria. Entretanto, não lista outras atividades que foram questionadas nesse bloco, tais como gestão de fluxos de caixa e análises de índices do balanço. O que foi possível perceber, analisando a Tabela 25, é que a Controladoria não tem relacionamento com a atividade de Tesouraria, sendo essa feita em uma área externa à Controladoria, denominada Tesouraria, o que não estaria aderente à ECBC. No entanto, há uma grande relação com as atividades de análise dos índices do balanço e análise dos concorrentes, que não estariam nas funções da ECBC, mas que, na prática, fazem parte das atividades da Controladoria nas instituições pesquisadas.

Na sequência, a função de Gestão das Informações foi questionada. Nesse grupo, foram listadas, apenas, três atividades, como: gestão dos sistemas de informações em geral, gestão das informações gerenciais e produção e geração de informações. A Tabela 26 contém as respostas encontradas.

Tabela 26 - Atividades da função gestão das informações

\begin{tabular}{l|c|c|c}
\hline \multirow{2}{*}{ Função: Gestão das Informações } & \multicolumn{2}{|c}{ Área responsável pela atividade } \\
\cline { 2 - 4 } & Controladoria & TI & Outras \\
\hline Atividades: & & & \\
\hline Gestão dos sistemas de informações em geral & $32,00 \%$ & $68,00 \%$ & $0,00 \%$ \\
\hline Gestão das informações gerenciais & $84,00 \%$ & $0,00 \%$ & $16,00 \%$ \\
\hline Produção e geração de informações & $76,00 \%$ & $20,00 \%$ & $4,00 \%$ \\
\hline \hline \% Médio na função & $64,00 \%$ & $29,33 \%$ & $6,67 \%$ \\
\hline
\end{tabular}

De acordo com os dados apresentados na Tabela 26, as atividades Gestão das informações gerenciais e Produção e geração de informações são atividades típicas da área de Controladoria, com $84 \%$ e $76 \%$, respectivamente. Já a área relacionada como Tecnologia da Informação (TI) tem destaque na Gestão dos sistemas de informações em geral, com 68\%. O Gráfico 17, a seguir, ilustra, na média, a responsabilidade de cada área para a função Gestão das Informações como um todo. 


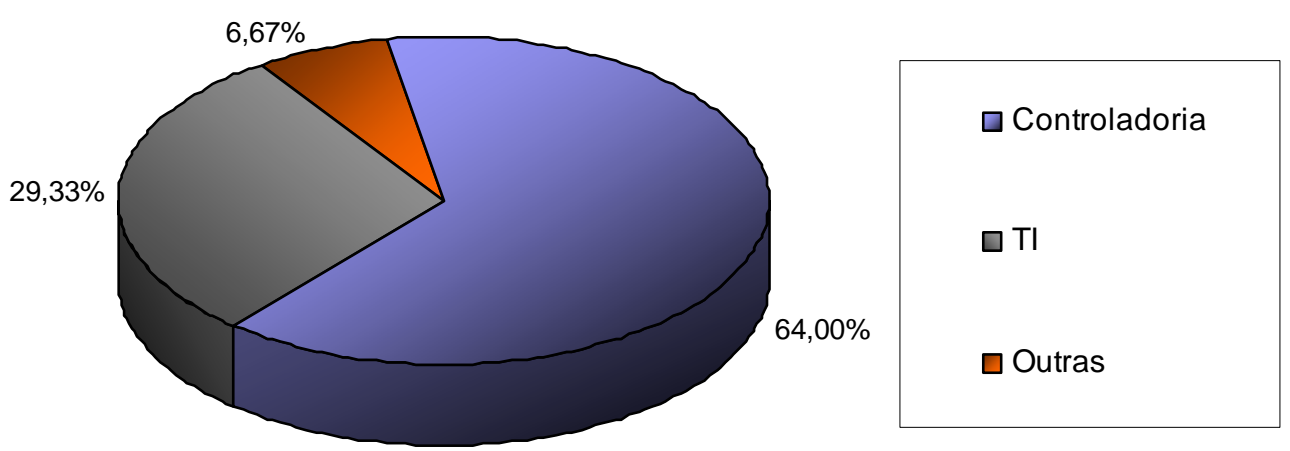

Gráfico 17 - Função gestão das informações

O Gráfico 17 evidencia que a área de Controladoria é responsável pela maior parte da Função Gestão das Informações com 64\%. A área relacionada como TI participa de uma parcela significativa com $29,33 \%$.

Relacionando mais uma vez a prática dos bancos pesquisados com a ECBC, pode-se entender que a Controladoria está aderente à ECBC no que tange ao controle das informações gerenciais. Contudo, quanto ao desenvolvimento e manutenção dos sistemas de informações em geral, esse fica sob a responsabilidade de uma área externa, denominada TI.

Por fim, a última função pesquisada nesse bloco foi a de Atendimento a Usuários Externos. Procurou-se entender a participação da Controladoria no atendimento aos diversos stakeholders da instituição, sejam acionistas, governo ou outros. A Tabela 27 apresenta os dados encontrados para esse grupo de atividades.

Tabela 27 - Atividades da função atendimento a usuários externos

\begin{tabular}{l|c|c|c|c|c|c}
\hline \multirow{2}{*}{$\begin{array}{c}\text { Função: Atendimento a } \\
\text { Usuários Externos }\end{array}$} & Controladoria & RI & $\begin{array}{c}\text { Auditoria } \\
\text { Interna }\end{array}$ & Jurídico & Contabilidade & \multirow{2}{*}{ Outras } \\
\cline { 2 - 7 } & & & & & & \\
\hline Atividades: & $48,00 \%$ & $24,00 \%$ & $0,00 \%$ & $4,00 \%$ & $4,00 \%$ & $20,00 \%$ \\
\hline Acionistas & $68,00 \%$ & $0,00 \%$ & $0,00 \%$ & $4,00 \%$ & $4,00 \%$ & $24,00 \%$ \\
\hline Governo & $84,00 \%$ & $0,00 \%$ & $4,00 \%$ & $0,00 \%$ & $8,00 \%$ & $4,00 \%$ \\
\hline Auditoria externa & $88,00 \%$ & $0,00 \%$ & $4,00 \%$ & $0,00 \%$ & $4,00 \%$ & $4,00 \%$ \\
\hline $\begin{array}{l}\text { Órgãos reguladores (BACEN, } \\
\text { CVM, SUSEP etc.) }\end{array}$ & $72,00 \%$ & $6,00 \%$ & $2,00 \%$ & $2,00 \%$ & $5,00 \%$ & $13,00 \%$ \\
\hline \hline \% Médio na função & &
\end{tabular}


Para cada atividade elencada na Tabela 27, a Controladoria aparece com parcelas significativas de participação. Os maiores destaques são o atendimento aos órgãos reguladores, auditoria externa e governo. Já o atendimento aos acionistas, a Controladoria tem uma participação significante, de 48\%, mas, também, se destaca a área de Relacionamento com Investidores (RI) com 24\%. Algumas instituições responderam que outras unidades são responsáveis por atendimento aos usuários externos, fazendo com que a área denominada "Outras" na tabela apresente uma parcela significativa de participação no atendimento aos acionistas e governo.

O Gráfico 18 ilustra as respostas da Tabela 27 para a função Atendimento a Usuários Externos como um todo.
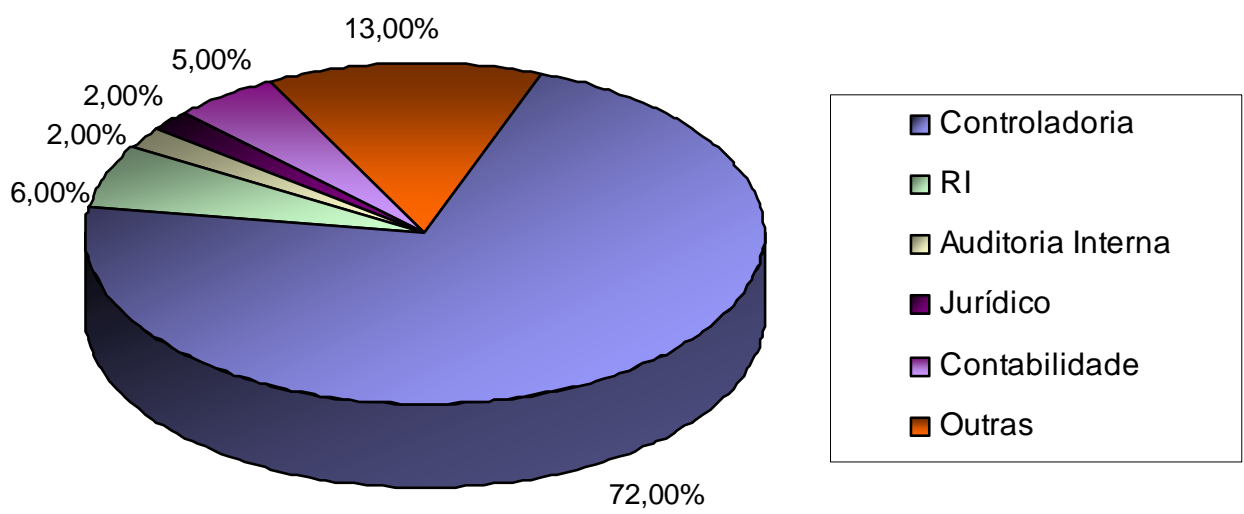

Gráfico 18 - Função atendimento a usuários externos

É possível perceber que, na média de todas as atividades da função Atendimento a Usuários Externos, a Controladoria é responsável por uma grande parcela: 72\%. As demais áreas dividem pequenas parcelas de participação na função como um todo.

No Capítulo 2, como complemento à ECBC, uma das funções típicas elencadas para a Controladoria em bancos era a de preparar e fornecer informações para as autoridades reguladoras, tais como: BACEN, CVM, SUSEP etc.. Além desse relacionamento com as autoridades, a função Atendimento aos Usuários Externos procurou abranger outras atividades, conforme elencadas na Tabela 27. Pelas análises feitas, é possível concluir que a Controladoria, no que tange à função de Atendimento aos Usuários Externos, está aderente ao que foi revisado no referencial teórico, sendo essa uma função, tipicamente, exercida pela área de Controladoria, com mais de $70 \%$ do total. 


\subsubsection{Papel desempenhado pela controladoria em processos específicos}

O Bloco 7 do questionário apresenta questões com o principal objetivo de entender a participação da Controladoria em processos específicos das instituições financeiras. Para fins de análises nessa seção, essas questões estão agrupadas em processos, resumidamente ligados ao planejamento estratégico, orçamento, análises de ambiente interno e externo, avaliação de desempenho, entre outros.

Assim como realizado na seção anterior, com a finalidade de se alcançar o objetivo desta pesquisa, para cada grupo de questões dessa seção será feita uma análise à luz da ECBC (Perspectiva 2), considerando-se, também, o complemento sobre funções de Controladoria para Bancos constante da plataforma teórica deste trabalho.

Para responder a cada questão desse Bloco, o respondente poderia optar entre nenhuma ou, no máximo, três das sete opções oferecidas como respostas, conforme o Quadro 3. A coluna denominada "Código", no quadro, será utilizada como legenda (eixo y) para os gráficos que apresentarão os resultados das questões.

Quadro 3 - Papel desempenhado pela controladoria

\begin{tabular}{|c|c|}
\hline Código & Papel da Controladoria \\
\hline A & Não participa do processo \\
\hline B & Apenas realiza as tarefas da sua área, assim como as demais do banco \\
\hline C & Fornece apoio/suporte informacional \\
\hline D & Executa o processo \\
\hline E & Coordena/organiza o processo \\
\hline F & É responsável pelo processo \\
\hline G & É corresponsável pelo processo \\
\hline
\end{tabular}

O primeiro grupo de questões trata do Planejamento Estratégico da instituição. Procurou-se investigar, nesse momento, o papel da Controladoria na Elaboração e no Controle do Planejamento Estratégico dos bancos pesquisados. O Gráfico 19, a seguir, apresenta os resultados obtidos nessa questão. 


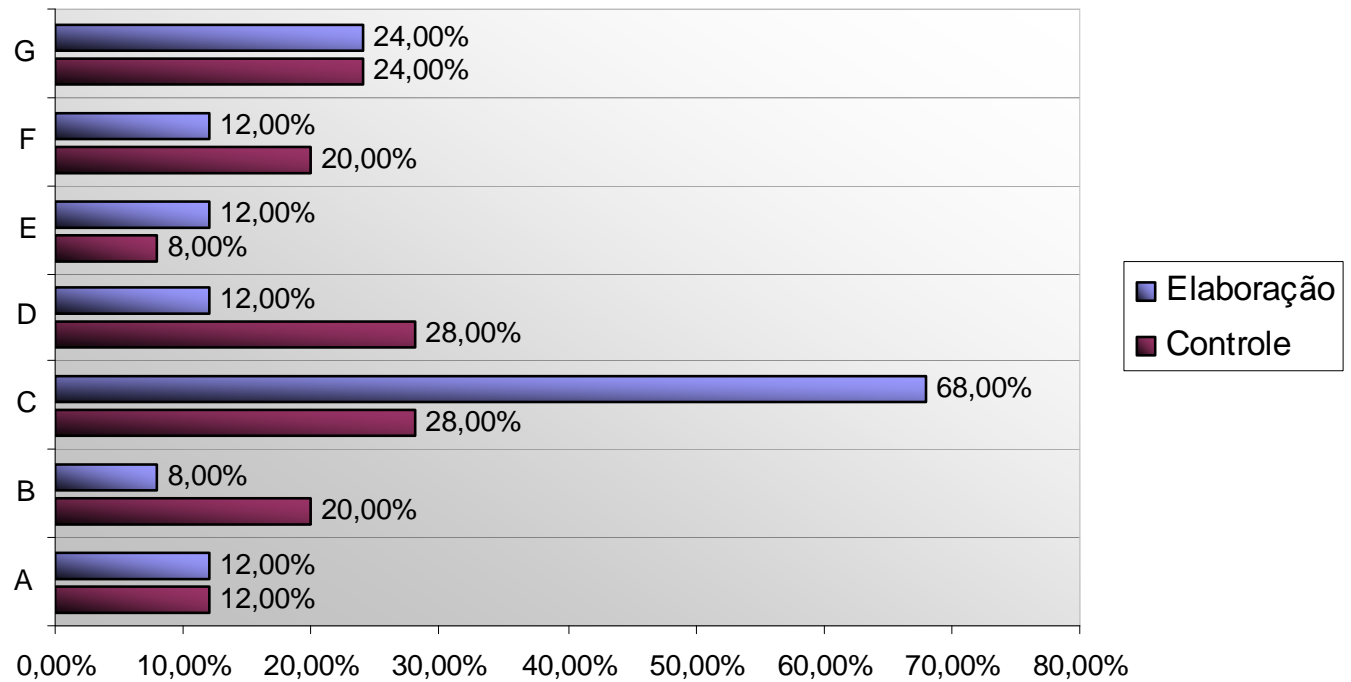

Gráfico 19 - Papel da Controladoria no planejamento estratégico

Analisando o Gráfico 19, pode-se inferir que, no processo de elaboração do Planejamento Estratégico, a Controladoria fornece apoio/suporte informacional para $68 \%$ dos respondentes. Em alguns bancos, ela, também, pode ser corresponsável por esse processo, apresentando um percentual de $24 \%$ nas escolhas. Essas duas alternativas foram relevantes no processo de elaboração do Planejamento Estratégico da instituição.

Já o controle do Planejamento Estratégico nas instituições pesquisadas apresentou respostas mais heterogêneas, mas destacando-se por fornecer apoio/suporte informacional com $28 \%$, seguido por ser a executora do processo com, também, 28\%. Dessa forma, tem-se que a participação da Controladoria, na elaboração e no controle do Planejamento Estratégico dos bancos participantes, está focada em fornecer apoio/suporte informacional e, em alguns casos, executar o controle do Planejamento Estratégico.

Percebe-se que, de acordo com essas análises, a ECBC está, parcialmente, refletida, na prática quanto ao Planejamento Estratégico das instituições. Pode-se concluir que, na prática, não é de responsabilidade da Controladoria coordenar o processo do Planejamento Estratégico, sendo que, na elaboração desse processo, ela se apresenta de uma forma predominante como uma área de suporte informacional.

Semelhante ao Planejamento Estratégico, as próximas questões desse Bloco procuraram entender a participação da Controladoria no processo de elaboração e controle do Orçamento 
dos bancos participantes da pesquisa. O Gráfico 20 apresenta o resultado agrupado dessas perguntas.

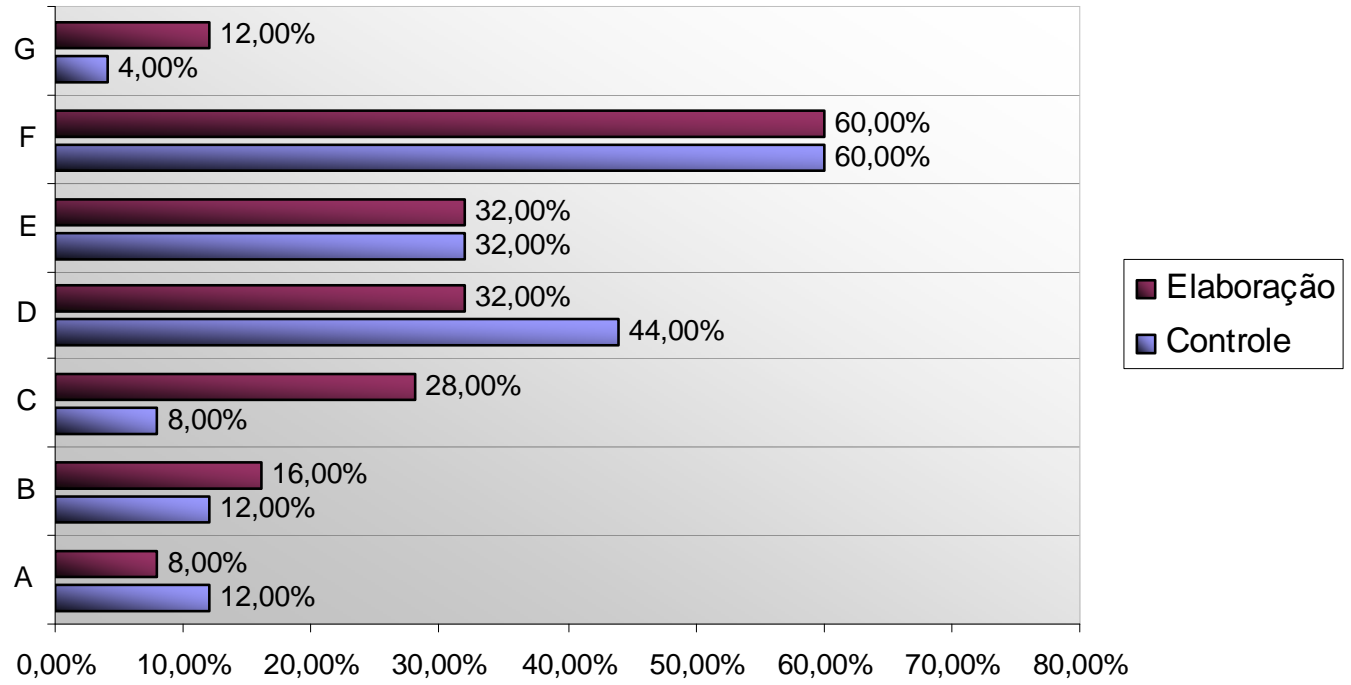

Gráfico 20 - Papel da controladoria no orçamento

De acordo com o Gráfico 20, fica evidente que a Controladoria, tanto no processo de elaboração, quanto no controle do Orçamento das instituições financeiras é considerada como Responsável pelo Processo na maioria das instituições, conforme percentual apresentado na legenda "F" de $60 \%$ para elaboração e controle.

Além dos respondentes terem marcado, em sua maioria, a resposta "F" - Responsável pelo Processo, outras duas opções, também, tiveram destaque sobre o papel da Controladoria no Orçamento dos bancos: a opção "D" - Executar o Processo e "E" - Coordenar/Organizar o Processo, ambas apresentando índices maiores de 30\%, tanto para execução quanto para controle.

Corroborando as análises acima, pode-se interpretar que, no processo de Orçamento das instituições financeiras, a Controladoria tem grande participação como responsável pelo processo e, também, na execução e coordenação do Orçamento. Essa prática encontrada está aderente à ECBC, a qual coloca a Controladoria como responsável por determinar as diretrizes do Orçamento. 
O próximo ponto investigado, nesse Bloco, foi sobre a participação da Controladoria nas análises do ambiente externo, interno e viabilidade de produtos e serviços. O Gráfico 21 ilustra os achados dessas questões.

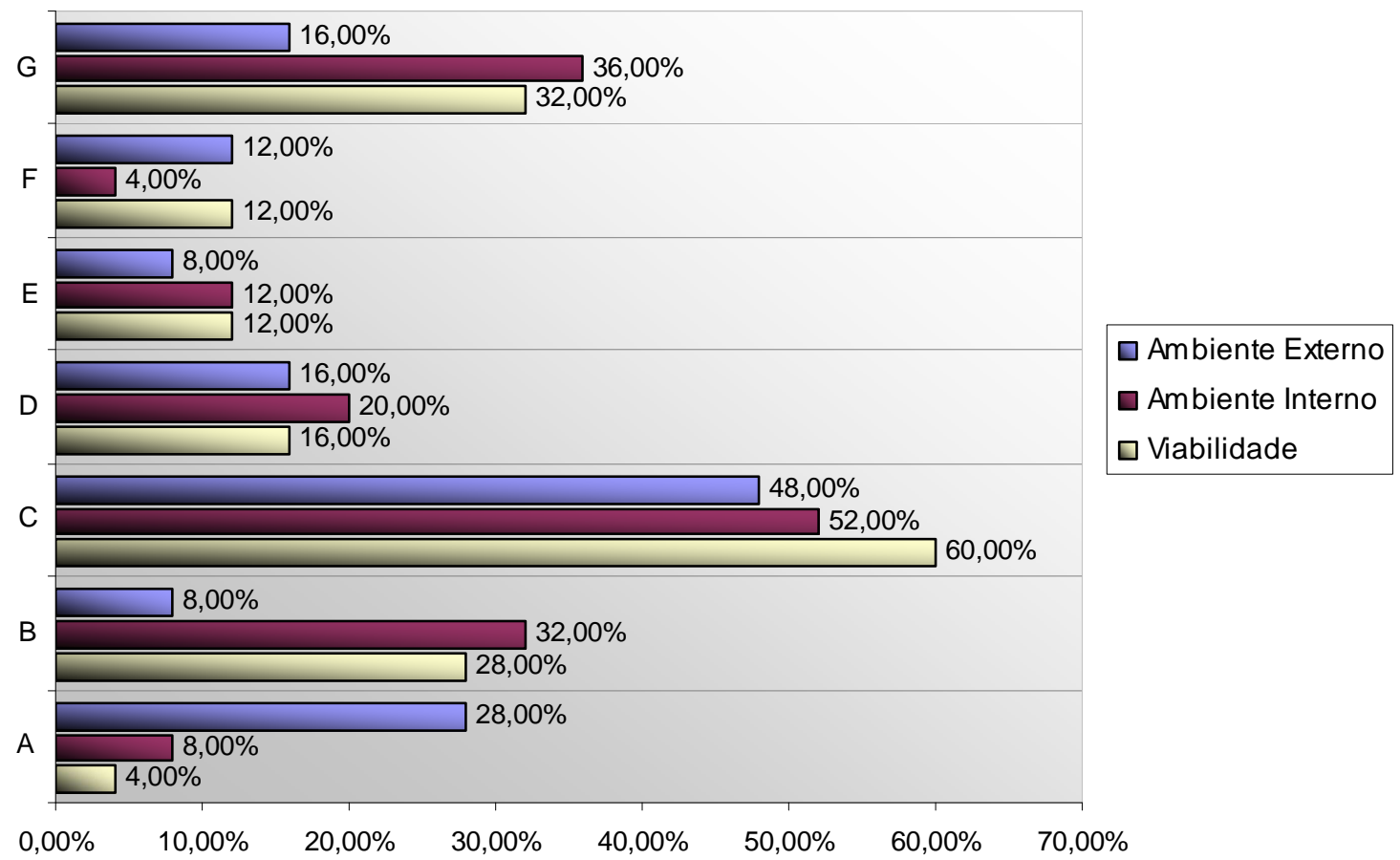

Gráfico 21 - Papel da controladoria nas análises

Para o item relacionado à análise do Ambiente Externo, a variável "C" - Fornece apoio/suporte informacional prepondera nas instituições com um índice de respostas de $48 \%$. Destaque-se, também, a opção "A" - Não participa do processo com $28 \%$. Em poucos casos a Controladoria tem alguma responsabilidade ou é a executora/coordenadora desse processo. Quanto à análise do Ambiente Interno, igualmente, destaca-se a variável "C" - Fornece apoio/suporte informacional nas respostas com 52\%. Todavia, a alternativa "G" - É corresponsável pelo processo aparece em 36\% das instituições, acrescentando maior responsabilidade da Controladoria nesse processo.

Seguindo as respostas obtidas quanto a análises do ambiente externo e interno, a análise de viabilidade de produtos e projetos apresenta, em $60 \%$ dos bancos, a variável "C" - Fornece apoio/suporte informacional. Há, também, um percentual significativo para a alternativa " $G$ " - É corresponsável pelo processo, com $32 \%$. 
No que tange a ECBC, as análises do Ambiente Externo, Interno e Viabilidade de produtos e projetos estão relacionadas ao processo de Planejamento, na gestão da empresa. Dessa forma, caberia à Controladoria coordenar esses processos de análises, porém o que se percebe, na prática, analisando o Gráfico 21, é que a Controladoria, em alguns casos, é corresponsável por esse processo e, na maior parte dos respondentes, a Controladoria tem como atribuição fornecer informações/suporte para outras áreas. Assim, pode-se considerar que a aderência à ECBC, nesse ponto, é de uma forma pouco significativa.

Outro processo específico que se procurou investigar, nesse Bloco, foi a participação da Controladoria na Avaliação de Desempenho, separado entre Avaliação de Desempenho de Gestores e de Produtos e Serviços.

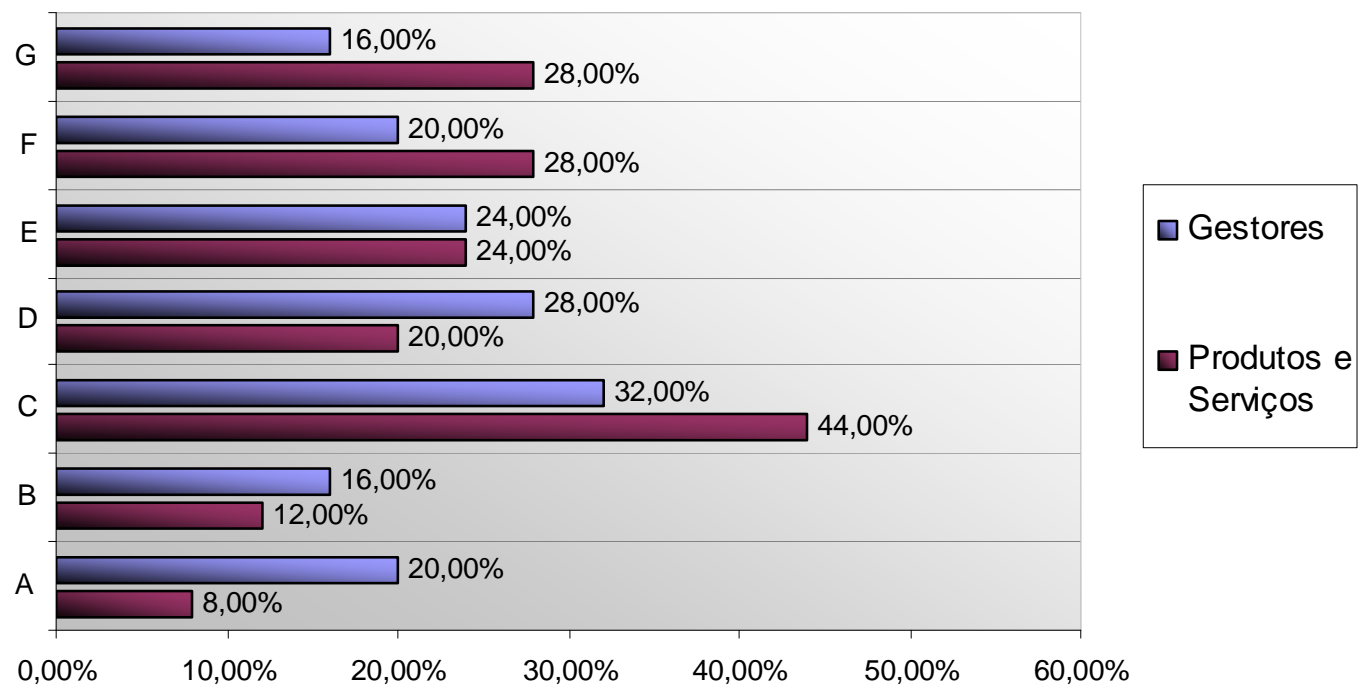

Gráfico 22 - Papel da controladoria na avaliação de desempenho

Analisando as informações apresentadas no Gráfico 22, quanto à Avaliação de Desempenho dos Gestores, entende-se que a Controladoria participa de diversas formas no processo, devido à grande distribuição das respostas entre as variáveis. Os maiores índices de respostas são as variáveis "C" - Fornece apoio/suporte informacional e "D" - Executa o Processo, com $32 \%$ e $28 \%$, respectivamente.

Assim como na Avaliação de Desempenho dos Gestores, da mesma forma pode-se entender a participação da Controladoria na Avaliação de Desempenho dos Produtos e Serviços, com destaque para a variável "C" - Fornece apoio/suporte informacional, com 44\% das respostas. 
As opções "F" - É responsável pelo processo e "G" - É corresponsável pelo processo aparecem ambas com $28 \%$ de escolha nas respostas dos participantes.

Dessa maneira, o processo de Avaliação de Desempenho não é de responsabilidade da Controladoria, sendo que, na maioria das instituições, a Controladoria participa, apenas, fornecendo informações/suporte às demais áreas. Em alguns poucos casos, percebe-se que, na prática, a Controladoria pode estar sendo considerada como executora, responsável ou corresponsável pelo processo. Assim, conclui-se que esse processo não está, adequadamente, aderente aos elementos da ECBC, com o complemento das funções e atribuições da Controladoria para bancos, o qual elenca a Avaliação de Desempenho como função típica da Controladoria.

O trabalho investigou, também, a participação da Controladoria na mensuração, análise e controle dos custos das instituições financeiras. O Gráfico 23 ilustra os achados dessa questão.

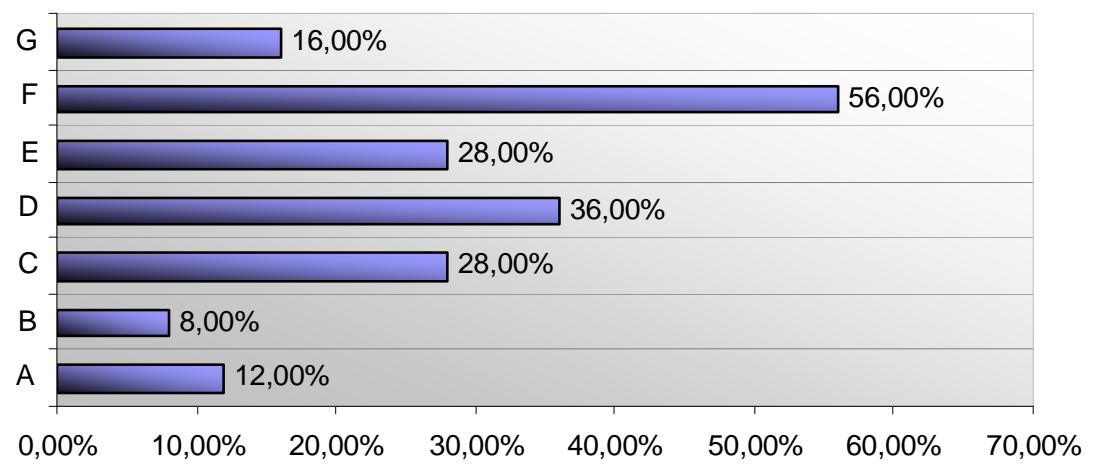

Gráfico 23 - Papel da controladoria na mensuração, análise e controle de custos

Note-se que, das respostas obtidas, 56\% das instituições apontaram a Controladoria como responsável pelo processo de Mensuração, Análise e Controle dos Custos. Além de ser responsável pelo processo nessas instituições, a Controladoria, também, apresenta destaque na opção “D” - Executa o processo, com $36 \%$.

Verificando-se o que ocorre, na prática, no que tange ao papel da Controladoria na Mensuração, Análise e Controle de Custos nas instituições financeiras, e o que foi colocado pela ECBC sobre a Controladoria e a função de custos, pode-se entender que, nesse caso, a ECBC está refletida na prática. 
De forma semelhante à questão anterior, procurou-se, também, investigar a participação da Controladoria no processo de Planejamento Tributário dos bancos pesquisados. O Gráfico 24 apresenta os percentuais de resposta para cada variável disponível.

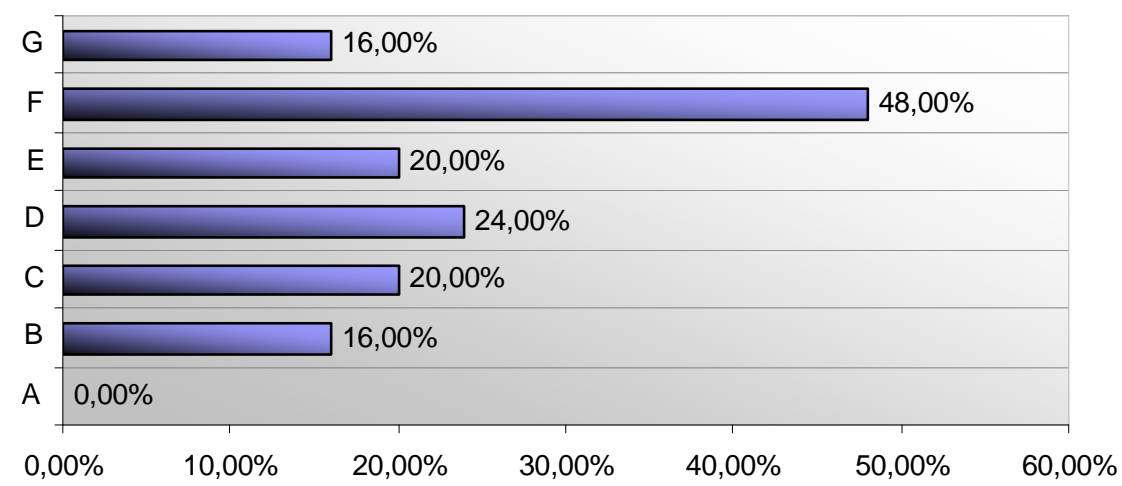

Gráfico 24 - Papel da controladoria no planejamento tributário

O Gráfico 24 demonstra que a opção "F" - É responsável pelo Processo apresentou $48 \%$ de participação nos bancos. O segundo maior destaque, nesse processo, foi a opção " $D$ " Executa o processo, com $24 \%$ de escolhas. Semelhantemente ao processo anterior, a Controladoria exerce grande responsabilidade nas instituições pesquisadas quanto ao processo de Planejamento Tributário das instituições financeiras.

Com essa análise, pode-se refletir que, no processo de Planejamento Tributário, a prática encontrada nas instituições está aderente ao que foi mencionado pela ECBC. Além das atividades tradicionais elencadas, tais como: atender obrigações fiscais, legais, normas e controlar impostos, as respostas encontradas, nessa seção, demonstram que a Controladoria tem grande participação na coordenação, sendo responsável pelo Planejamento Tributário como um todo, indo além do previsto na ECBC.

A última questão analisada, nesse Bloco, investigou a participação da Controladoria no Controle de Riscos das instituições. O Gráfico 25, a seguir, expõe as respostas alcançadas. 


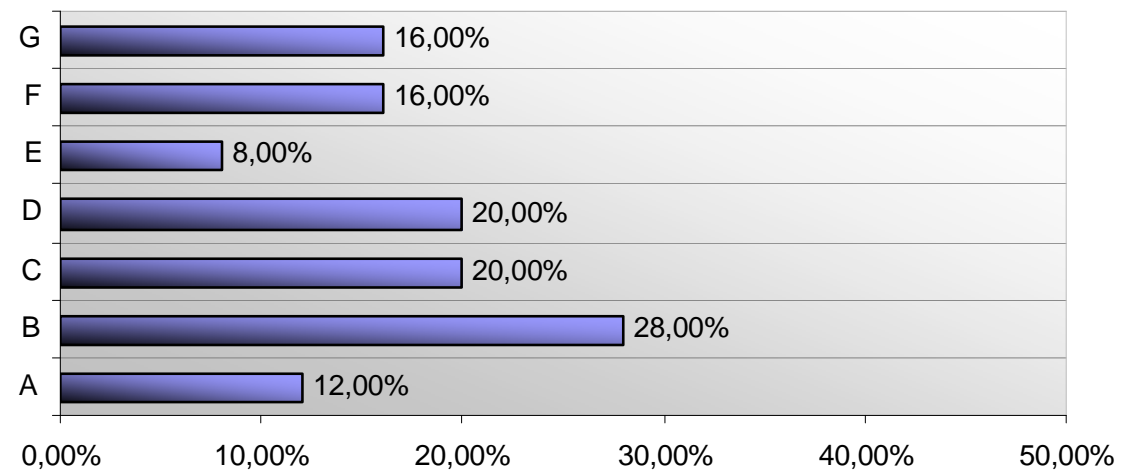

Gráfico 25 - Papel da controladoria no controle de riscos

Verificando os dados apresentados no Gráfico 25, percebe-se que, em 28\% das instituições pesquisadas, a Controladoria, apenas, realiza as tarefas de sua área, assim como as demais áreas do banco, no que tange ao Controle de Riscos. Os outros destaques estão relacionados às opções "C" - Fornece apoio/suporte informacional e "D" - Executa o processo, ambas com apenas $20 \%$ nas respostas. Veja-se que há um baixo percentual para todas as demais opções desse processo, principalmente com relação às opções "G" e "F", que implicariam em maiores responsabilidades da Controladoria no processo de Controle dos Riscos da instituição.

Assim como já exposto na seção anterior, quando foi abordada a função de Riscos e Controles Internos, em se tratando de Controle de Riscos especificamente, a Controladoria não é responsável ou coordenadora do processo, destacando-se, apenas, realizando as atribuições que lhe cabem nesse processo, assim como as demais áreas do banco. Dessa forma, nesse processo, não se apresenta uma aderência ao que foi apontado pela ECBC no referencial teórico deste trabalho.

\subsection{Análise comparativa dos resultados}

Devido à diversidade de algumas práticas da Controladoria entre os bancos pesquisados, revelada na seção anterior, optou-se por apresentar, nessa seção, uma estratificação dos dados obtidos nas entrevistas e questionários, realizando-se uma análise comparativa entre diferentes grupos das instituições financeiras pesquisadas. 
Para evitar a identificação de alguma instituição, garantindo o sigilo necessário aos bancos participantes da pesquisa, os resultados da estratificação não serão, analiticamente, expostos em tabelas, mas explicados de forma resumida em quadros.

Esses quadros dão as informações que foram selecionadas por apresentarem maior divergência entre os respondentes, organizadas da seguinte forma: (i) descrição da unidade que exerce as funções de Controladoria; (ii) denominação do profissional responsável pela Controladoria; (iii) as funções exercidas pela Controladoria e (iv) a participação da Controladoria em processos específicos.

As próximas seções encarregam-se de apresentar as três estratificações realizadas neste estudo, bem como uma análise comparativa entre os grupos de cada estratificação: (a) Estratificação 1: Sete maiores bancos respondentes e demais bancos; (b) Estratificação 2: Bancos de capital nacional e bancos de capital estrangeiro e (c) Estratificação 3: Bancos privados e bancos estatais. Note-se que, para todas as estratificações, foram utilizados apenas dados dos bancos que responderam à pesquisa.

\subsubsection{Estratificação 1: sete maiores bancos participantes e demais bancos}

Primeiramente, decidiu-se por estratificar os dados obtidos em dois grupos: os sete maiores bancos respondentes da pesquisa e os demais bancos, também respondentes. $\mathrm{O}$ critério para a seleção de tamanho das instituições foi o seu Patrimônio Líquido Legal ("PL Legal”). Optouse por realizar essa segregação, pois as sete maiores instituições respondentes representam um montante de mais de 60\% do Patrimônio Líquido Legal e mais de 70\% dos Ativos totais do somatório total dos 50 (cinquenta) bancos selecionados. Com essa grande diferença de porte, supõe-se que a estrutura de áreas dessas instituições seja diferente das instituições de menor porte, tanto pelo número de funcionários que, supostamente, divergem, quanto à diversidade de operações e segmentos.

O Quadro 4, a seguir, apresenta a descrição das características encontradas para o grupo dos sete maiores bancos respondentes da pesquisa. 
Quadro 4 - Características dos sete maiores bancos pesquisados

\begin{tabular}{|c|c|}
\hline \multirow{2}{*}{$\begin{array}{l}\text { Descrição da Unidade } \\
\text { que exerce funções de } \\
\text { Controladoria }\end{array}$} & $\begin{array}{l}\text { Apenas } 28,57 \% \text { desses bancos possuem unidade denominada Controladoria e } \\
71,43 \% \text { não. }\end{array}$ \\
\hline & $\begin{array}{l}\text { Dos que não possuem unidade denominada Controladoria, } 60 \% \text { deles } \\
\text { denominam a área que exerce as funções de Controladoria como Finanças; em } \\
20 \% \text { não há denominação e } 20 \% \text { denomina-se como Vice-Presidência. }\end{array}$ \\
\hline $\begin{array}{l}\text { Denominação do } \\
\text { Profissional } \\
\text { responsável pela } \\
\text { Controladoria }\end{array}$ & $\begin{array}{l}\text { Predomina a denominação CFO, com } 42,86 \% \text { dos cargos do responsável pela } \\
\text { unidade de Controladoria (sendo essa denominada Controladoria ou outra } \\
\text { denominação). } \\
\text { Outras denominações de cargos do profissional responsável: Diretor de } \\
\text { Controladoria, Diretor Executivo, Diretor Gerente e Vice-Presidente, com } \\
14,29 \% \text { cada. }\end{array}$ \\
\hline \multirow{6}{*}{$\begin{array}{l}\text { Funções exercidas pela } \\
\text { Controladoria }\end{array}$} & $\begin{array}{l}\text { A maioria dessas instituições, com } 85,71 \% \text {, realizam função de Contabilidade } \\
\text { Societária na Controladoria. }\end{array}$ \\
\hline & 80,95\% realizam função de Contabilidade Fiscal na Controladoria. \\
\hline & $\begin{array}{l}\text { A função de Riscos e Controles Internos aparece, apenas, com } 20,41 \% \text { na } \\
\text { Controladoria, destacando-se na área de Riscos com } 57,14 \% \text {. }\end{array}$ \\
\hline & $\begin{array}{l}\text { A função Finanças aparece em 50\%, sendo realizada, também, na Tesouraria e } \\
\text { na área Financeira, com } 35,71 \% \text { e 14,29\%, respectivamente. }\end{array}$ \\
\hline & $85,71 \%$ da função de Sistemas de Informações estão sob a Controladoria. \\
\hline & $\begin{array}{l}75 \% \text { da função Atendimento a Usuários Externos realizam-se na } \\
\text { Controladoria. }\end{array}$ \\
\hline \multirow{3}{*}{$\begin{array}{l}\text { Participação da } \\
\text { Controladoria em } \\
\text { Processos Específicos }\end{array}$} & $\begin{array}{l}\text { Na maioria dessas instituições, o papel da Controladoria no Planejamento } \\
\text { Estratégico é de fornecer apoio/suporte informacional e, em alguns casos, ser } \\
\text { corresponsável pelo processo. } \\
100 \% \text { desses bancos apontaram a Controladoria como responsável pelo } \\
\text { Orçamento, além de, em muitos casos, coordenar o processo como um todo. }\end{array}$ \\
\hline & $\begin{array}{l}\text { No processo de análises do ambiente externo, interno e viabilidade de projetos } \\
\text { e produtos, a Controladoria tem, em grande parte, participação apenas } \\
\text { fornecendo apoio/suporte informacional. Em alguns casos, destaca-se como } \\
\text { corresponsável por esse processo. } \\
\text { Para } 71,43 \% \text { dessas instituições, a Controladoria é responsável pelo processo } \\
\text { de Avaliação de Desempenhos (gestor e produtos), destacando-se, também, } \\
\text { como fornecedora de apoio/suporte informacional e como executora do } \\
\text { processo. }\end{array}$ \\
\hline & $\begin{array}{l}\text { Os processos de Controle de Custos e Planejamento Tributário apresentam } \\
85,71 \% \text { e } 71,43 \% \text {, respectivamente, como responsabilidade da Controladoria. } \\
\text { Destaque-se, também, que a Controladoria é, em muitos casos, executora ou } \\
\text { coordenadora desses processos. } \\
\text { O Controle de Riscos foi apontado, em sua maioria, que a Controladoria não } \\
\text { participa desse processo. }\end{array}$ \\
\hline
\end{tabular}

Para facilitar a visualização das funções gerais, descritas no Quadro 4, o Gráfico 26, a seguir, resume a participação da Controladoria em cada uma dessas funções, comparativamente à participação de outras áreas. Os dados são referentes ao estrato analisado, ou seja, aos sete maiores bancos pesquisados. 


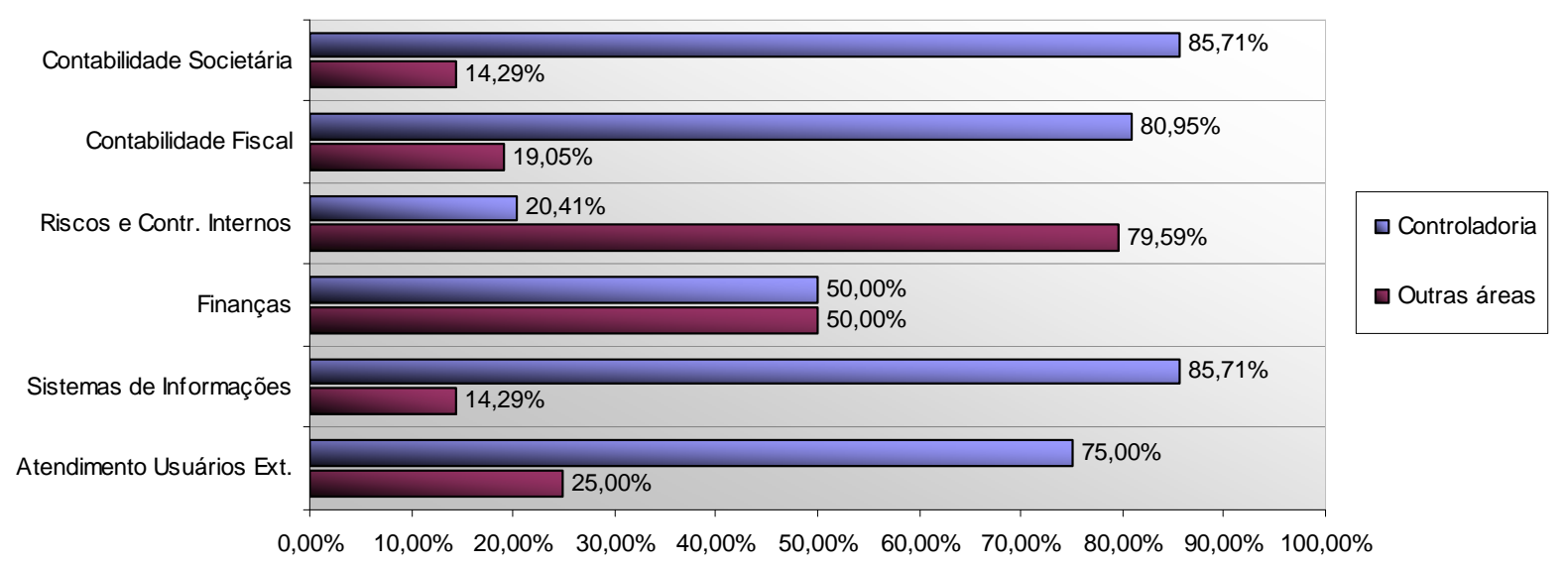

Gráfico 26 - Funções gerais da controladoria nos sete maiores bancos pesquisados

Percebe-se que para esse estrato, a Controladoria tem grande participação nas funções de Contabilidade Societária $(85,71 \%)$, Contabilidade Fiscal $(80,95 \%)$, Sistema de Informações $(85,71 \%)$ e Atendimento aos Usuários Externos (75\%).

O Quadro 5 apresenta um resumo das características dos demais bancos pesquisados, que não fazem parte do grupo dos sete maiores respondentes.

\section{Quadro 5 - Características dos demais bancos pesquisados}

\begin{tabular}{|c|c|}
\hline & \\
\hline \multirow[b]{2}{*}{$\begin{array}{l}\text { Descrição da Unidade } \\
\text { que exerce funções de } \\
\text { Controladoria }\end{array}$} & Em 83,33\% dessas instituições, há uma unidade denominada Controladoria. \\
\hline & $\begin{array}{l}\text { Dos } 16,67 \% \text { que não possuem uma unidade nomeada Controladoria, esses } \\
\text { utilizam as denominações Finanças, Assessoria de Planejamento e Controle e } \\
\text { Contabilidade Geral, com } 33,33 \% \text { cada um. }\end{array}$ \\
\hline $\begin{array}{l}\text { Denominação do } \\
\text { Profissional } \\
\text { responsável pela } \\
\text { Controladoria }\end{array}$ & $\begin{array}{l}\text { Para esse grupo de instituições, destaca-se a denominação Gerente de } \\
\text { Controladoria, para o profissional responsável pela Controladoria, com mais } \\
\text { de } 30 \% \text { de participação. Outro destaque, com } 22 \% \text { de participação, é o cargo } \\
\text { de Controller. Aparecem, também, em poucos casos, cargos relacionados a } \\
\text { Diretor e Superintendente (menos de } 10 \%) \text {. }\end{array}$ \\
\hline \multirow{6}{*}{$\begin{array}{l}\text { Funções exercidas pela } \\
\text { Controladoria }\end{array}$} & $\begin{array}{l}\text { A função de Contabilidade Societária é exercida na Controladoria em 71,11\% } \\
\text { das instituições desse grupo. A área de Contabilidade destaca-se com 27,78\%. }\end{array}$ \\
\hline & $\begin{array}{l}62,96 \text { da função Contabilidade Fiscal está sob a Controladoria. Também } \\
\text { destaca-se a área de Contabilidade, com } 22,22 \% \text {. }\end{array}$ \\
\hline & $\begin{array}{l}\text { Riscos e Controles internos dividem-se, em sua maior parte, entre } \\
\text { Controladoria e Área de Riscos, com } 36,51 \% \text { e } 32,54 \% \text {, respectivamente. }\end{array}$ \\
\hline & $\begin{array}{l}\text { Quanto à função de finanças, estão sob a Controladoria, apenas, } 30,56 \% \text {. } \\
\text { Destacando-se, aqui, a Tesouraria com } 29,17 \% \text { e Outras áreas com mais de } \\
20 \% \text {. }\end{array}$ \\
\hline & $\begin{array}{l}55,56 \% \text { da função Sistema de Informações são realizadas na Controladoria, } \\
\text { destacando-se, também, a área de TI com 35,19\%. }\end{array}$ \\
\hline & 70,83\% do Atendimento a Usuários Externos é realizado na Controladoria. \\
\hline
\end{tabular}


continuação

\begin{tabular}{|c|l|}
\hline \multirow{5}{*}{$\begin{array}{c}\text { Participação da } \\
\text { Controladoria em } \\
\text { Processos Específicos }\end{array}$} & $\begin{array}{l}\text { Estratégico é de fornecer apoio/suporte informacional, sendo que não há outro } \\
\text { destaque do papel da Controladoria nesse processo. } \\
\text { Apenas 44,44\% desses bancos apontaram a Controladoria como responsável } \\
\text { pelo Orçamento, além de, em 36,11\% ela ser a executora do processo. }\end{array}$ \\
\cline { 2 - 3 } & $\begin{array}{l}\text { No processo de análises do ambiente externo, interno e viabilidade de projetos } \\
\text { e produtos, a Controladoria tem, em grande parte, participação, apenas, } \\
\text { Avaliação de Desempenhos (gestor e produtos), não se apresentando } \\
\text { responsável ou coordenadora desse processo. }\end{array}$ \\
\cline { 2 - 3 } & $\begin{array}{l}\text { Nos processos de Controle de Custos e Planejamento tributário, a } \\
\text { Controladoria destaca-se na função de Responsável pelo processo, porém com } \\
\text { percentuais não muito altos (44,44\% e 38,89\%, respectivamente). Não há } \\
\text { evidências de que a Controladoria seja responsável por esses processos. } \\
\text { Quanto ao Controle de Riscos, a Controladoria, também, não é responsável e } \\
\text { não organiza esse processo. }\end{array}$ \\
\hline
\end{tabular}

O Gráfico 27 apresenta as funções gerais da Controladoria e o quanto essa exerce de cada função, de acordo com as explicações dadas no Quadro 5.

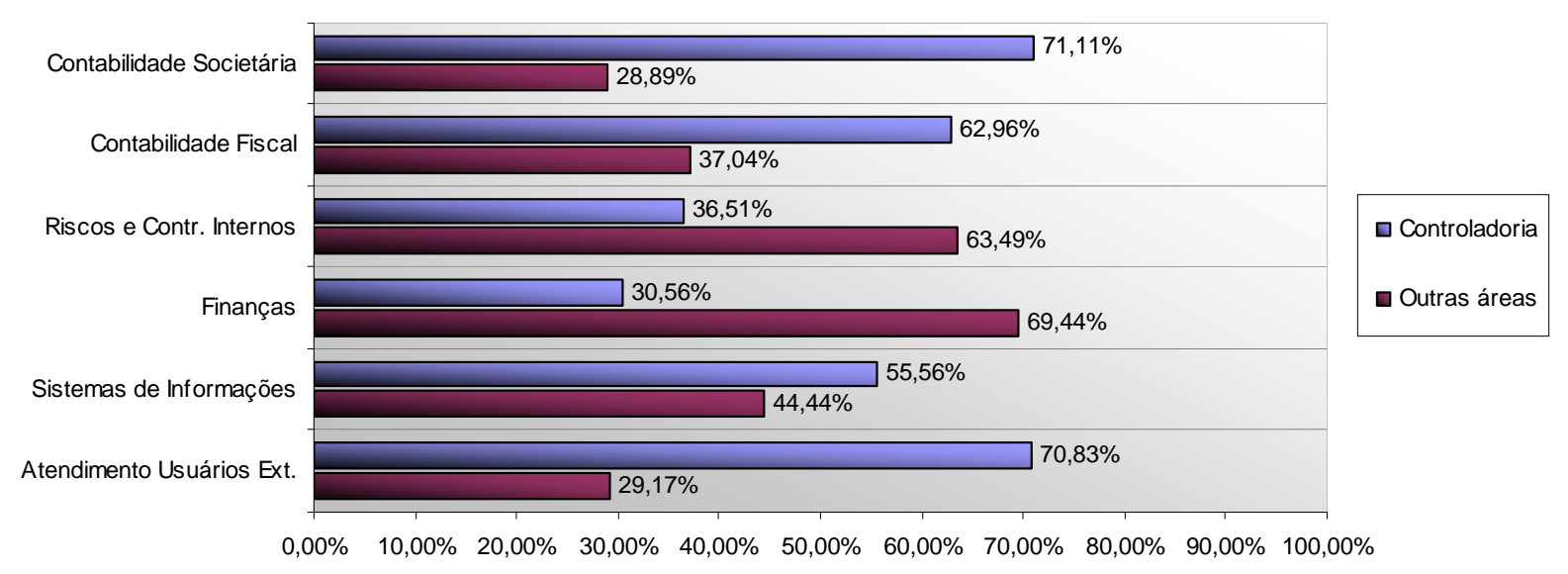

Gráfico 27 - Funções gerais da controladoria nos demais bancos

Comparativamente ao Gráfico 26, é possível perceber, no Gráfico 27, que a Controladoria, também, se destaca nas funções de Contabilidade Societária, Contabilidade Fiscal, Sistemas de Informações e Atendimento aos Usuários Externos. Entretanto, as instituições que fazem parte do grupo dos sete maiores bancos respondentes apresentam percentuais mais elevados para essas funções, sobre serem funções típicas da área de Controladoria.

Quanto aos processos específicos, a área de Controladoria, no grupo dos sete maiores bancos pesquisados, destaca-se nos processos de Orçamento, sendo considerada como a responsável pelo processo, e no Controle de Custos e Planejamento Tributário, sendo, também, enfatizada 
como responsável por esses processos. Em contrapartida, nos demais bancos, a Controladoria não aparece como responsável por nenhum processo específico. Semelhantemente, para ambos os grupos, a Controladoria não tem participação no processo de Controle de Riscos das instituições.

\subsubsection{Estratificação 2: bancos de capital nacional e de capital estrangeiro}

A segunda estratificação realizada com as respostas dos bancos participantes foi a segregação entre bancos de capital nacional e bancos de capital estrangeiro. Supôs-se necessário essa estratificação, partindo-se do entendimento de que os bancos de capital estrangeiro têm suas sedes em outros países e, com isso, possam manter uma estrutura diferente nos demais países que operam. Entendeu-se que essa diferença de estruturação, possivelmente, poderia interferir na área de Controladoria dessas instituições, o que apontariam divergências nas práticas de Controladoria quando comparadas com as instituições de capital nacional, sediadas no Brasil.

O Quadro 6 apresenta, de forma resumida, as características do grupo dos bancos de capital nacional.

\begin{tabular}{|c|c|}
\hline \multicolumn{2}{|r|}{ Quadro 6 - Características dos bancos de capital nacional } \\
\hline \multirow[b]{2}{*}{$\begin{array}{l}\text { Descrição da Unidade } \\
\text { que exerce funções de } \\
\text { Controladoria }\end{array}$} & Em $68,75 \%$ dessas instituições, há uma área denominada Controladoria. \\
\hline & $\begin{array}{l}\text { Para os } 31,25 \% \text { restantes, as denominações para a área que exerce funções de } \\
\text { Controladoria se dividem, igualmente, entre Finanças, Assessoria de } \\
\text { Planejamento e Controle, Contabilidade Geral, Vice-Presidência de Controles } \\
\text { e Riscos e Sem Denominação. }\end{array}$ \\
\hline $\begin{array}{l}\text { Denominação do } \\
\text { Profissional } \\
\text { responsável pela } \\
\text { Controladoria }\end{array}$ & $\begin{array}{l}\text { Em } 37,50 \% \text {, o profissional responsável pela Controladoria é denominado } \\
\text { Gerente de Controladoria. Destacam-se, também, com } 12,50 \% \text { cada, os cargos } \\
\text { de Diretor de Controladoria, Diretor Executivo e Superintendente. }\end{array}$ \\
\hline \multirow{3}{*}{$\begin{array}{l}\text { Funções exercidas pela } \\
\text { Controladoria }\end{array}$} & $\begin{array}{l}\text { Em } 61,25 \% \text { desses bancos, a função Contabilidade Societária está sob a } \\
\text { Controladoria. } \\
\text { Para } 31,25 \% \text {, essa função está na Contabilidade. }\end{array}$ \\
\hline & $\begin{array}{l}\text { A função de Contabilidade fiscal é exercida em } 60,42 \% \text { pela Controladoria, } \\
\text { sendo que } 25 \% \text { é exercida na Contabilidade. }\end{array}$ \\
\hline & $\begin{array}{l}\text { Riscos e Controles Internos estão em } 41,07 \% \text { concentrado na área de Riscos, } \\
\text { mas a Controladoria exerce } 30,36 \% \text { dessa função. }\end{array}$ \\
\hline
\end{tabular}


continuação

\begin{tabular}{|c|c|}
\hline \multirow{3}{*}{$\begin{array}{l}\text { Funções exercidas pela } \\
\text { Controladoria }\end{array}$} & $\begin{array}{l}\text { A função de Finanças está presente na Controladoria em } 32,81 \% \text { desses } \\
\text { bancos, com destaque de } 28,13 \% \text { para a área de Tesouraria. }\end{array}$ \\
\hline & 70,83\% da função de Sistema de Informações estão na Controladoria. \\
\hline & $\begin{array}{l}70,31 \% \text { da função de Atendimento aos Usuários Externos estão na } \\
\text { Controladoria. }\end{array}$ \\
\hline \multirow{3}{*}{$\begin{array}{c}\text { Participação da } \\
\text { Controladoria em } \\
\text { Processos Específicos }\end{array}$} & $\begin{array}{l}\text { Na maioria }(46,88 \%) \text { dessas instituições o papel da Controladoria no } \\
\text { Planejamento Estratégico é de fornecer apoio/suporte informacional. Para } \\
21,88 \% \text {, a Controladoria é responsável por esse processo. } \\
59,38 \text { desses bancos apontaram a Controladoria como responsável pelo } \\
\text { Orçamento, além de, em 34,38\% ela ser a executora do processo. }\end{array}$ \\
\hline & $\begin{array}{l}\text { No processo de análises do ambiente externo, interno e viabilidade de projetos } \\
\text { e produtos, a Controladoria tem, em grande parte, participação, apenas, } \\
\text { fornecendo apoio/suporte informacional. } \\
\text { Dessa mesma forma, a Controladoria é responsável pelo processo de } \\
\text { Avaliação de Desempenhos (gestor e produtos), não se apresentando } \\
\text { responsável por esse processo. }\end{array}$ \\
\hline & $\begin{array}{l}\text { Nos processos de Controle de Custos e Planejamento tributário, a } \\
\text { Controladoria destaca-se na função de responsável pelo processo. São dadas, } \\
\text { ainda, outras atribuições à Controladoria, tais como coordenadora e executora } \\
\text { dos processos. } \\
\text { Quanto ao Controle de Riscos, a Controladoria não é responsável e não } \\
\text { organiza esse processo. }\end{array}$ \\
\hline
\end{tabular}

O Gráfico 28 ilustra a participação nas funções gerais elencadas no Quadro 6, pela área de Controladoria dos bancos de capital nacional.

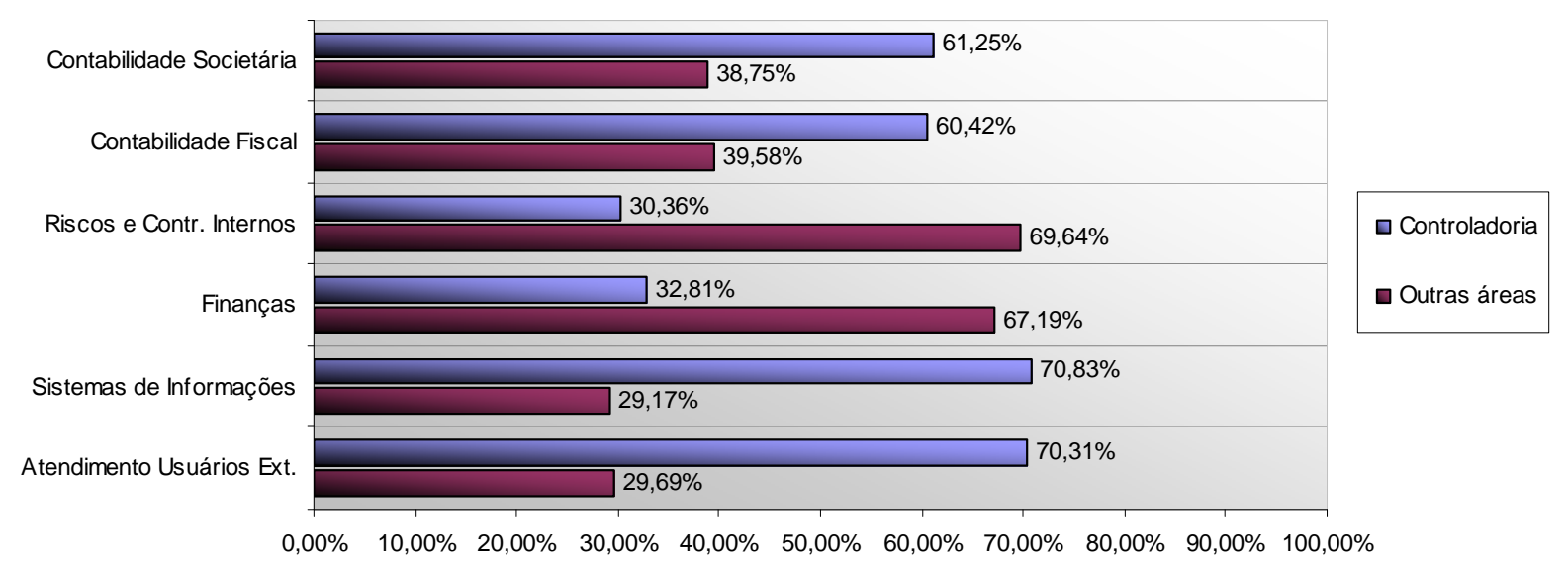

Gráfico 28 - Funções gerais da controladoria nos bancos de capital nacional

De acordo com os dados apresentados, as duas funções que são, em grande parte, exercidas na Controladoria são Sistemas de Informações e Atendimento a Usuários Externos. Percebe-se, analisando o Gráfico 28, que as funções de Riscos, Controles Internos e Finanças são amplamente realizadas por outras áreas. 
No segundo grupo da Estratificação 2, estão os bancos de capital estrangeiro. O Quadro 7 apresenta as características encontradas para essas instituições.

Quadro 7 - Características dos bancos de capital estrangeiro

\begin{tabular}{|c|c|}
\hline \multirow[b]{2}{*}{$\begin{array}{l}\text { Descrição da Unidade } \\
\text { que exerce funções de } \\
\text { Controladoria }\end{array}$} & Em 66,67\% dessas instituições, há uma área denominada Controladoria. \\
\hline & $\begin{array}{l}\text { Para os } 33,33 \% \text { que não possuem uma área nomeada Controladoria, a } \\
\text { denominação dada para a área que exerce funções de Controladoria é Finanças, } \\
\text { em } 100 \% \text { deles. }\end{array}$ \\
\hline $\begin{array}{l}\text { Denominação do } \\
\text { Profissional responsável } \\
\text { pela Controladoria }\end{array}$ & $\begin{array}{l}\text { Os profissionais responsáveis pela Controladoria nesses bancos são, na maior } \\
\text { parte, denominados CFO e Controller. }\end{array}$ \\
\hline \multirow{6}{*}{$\begin{array}{l}\text { Funções exercidas pela } \\
\text { Controladoria }\end{array}$} & $\begin{array}{l}\text { Para essas instituições, a função de Contabilidade Societária está contemplada em } \\
100 \% \text { na área de Controladoria. }\end{array}$ \\
\hline & A função Contabilidade Fiscal está em $81,48 \%$ na Controladoria. \\
\hline & $\begin{array}{l}\text { Riscos e Controles Internos dividem-se, principalmente, entre Controladoria } \\
(34,92 \%) \text { e Área de Riscos }(36,51 \%) \text {. }\end{array}$ \\
\hline & $\begin{array}{l}\text { A função de finanças está sob a Controladoria em } 41,67 \% \text { dessas instituições, } \\
\text { destacando-se, também, na área de Tesouraria, com } 36,11 \% \text {. }\end{array}$ \\
\hline & $\begin{array}{l}51,85 \% \text { da função Sistemas de Informações está sob a Controladoria, sendo que } \\
40,47 \% \text { está na área denominada TI. }\end{array}$ \\
\hline & A Controladoria detém $75 \%$ da função Atendimento aos Usuários Externos. \\
\hline \multirow{3}{*}{$\begin{array}{c}\text { Participação da } \\
\text { Controladoria em } \\
\text { Processos Específicos }\end{array}$} & $\begin{array}{l}\text { Na maioria }(46,88 \%) \text { dessas instituições, o papel da Controladoria no } \\
\text { Planejamento Estratégico é de fornecer apoio/suporte informacional. Para } \\
38,89 \% \text {, a Controladoria é corresponsável por esse processo. } \\
61,11 \% \text { desses bancos apontaram a Controladoria como responsável pelo } \\
\text { Orçamento, além de, em } 50 \% \text { ela ser a executora do processo. }\end{array}$ \\
\hline & $\begin{array}{l}\text { No processo de análises do ambiente externo, interno e viabilidade de projetos e } \\
\text { produtos, a Controladoria tem, em grande parte, participação, apenas, fornecendo } \\
\text { apoio/suporte informacional. } \\
\text { Dessa mesma forma, a Controladoria é responsável pelo processo de Avaliação } \\
\text { de Desempenhos (gestor e produtos), não se apresentando responsável por esse } \\
\text { processo e, em alguns casos, é a executora da Avaliação de Desempenhos. }\end{array}$ \\
\hline & $\begin{array}{l}\text { Nos processos de Controle de Custos e Planejamento tributário, a Controladoria } \\
\text { destaca-se como responsável pelo processo. São dadas, ainda, outras atribuições à } \\
\text { Controladoria, tal como executora dos processos. } \\
\text { Quanto ao Controle de Riscos, a Controladoria não é responsável e não organiza } \\
\text { esse processo, destacando-se que, em algumas instituições, ela é a executora do } \\
\text { Controle de Riscos com } 44,44 \% \text {. }\end{array}$ \\
\hline
\end{tabular}


No Gráfico 29 estão apresentadas as funções gerais da Controladoria, com a distribuição de funções tipicamente realizadas pela área de Controladoria e pelas demais áreas.

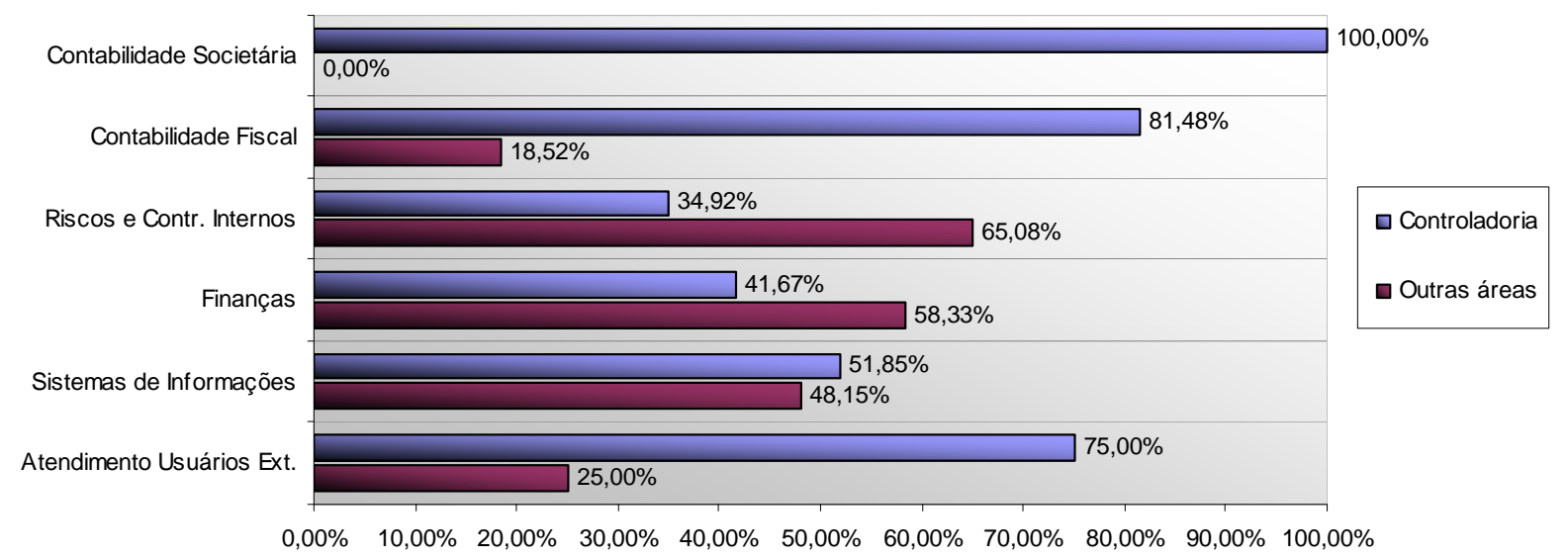

Gráfico 29 - Funções gerais da controladoria nos bancos de capital estrangeiro

O Gráfico 29 evidencia que 100\% da função de Contabilidade Societária é exercida na área de Controladoria. Elevados percentuais nas funções Contabilidade Fiscal e Atendimento a Usuários Externos permitem deduzir que essas são funções típicas da área de Controladoria nas instituições de capital estrangeiro.

Analisando comparativamente os Gráficos 28 e 29, os quais se referem aos bancos de capital nacional e de capital estrangeiro, respectivamente, pode-se perceber que, nos bancos de capital estrangeiro, as funções Contabilidade Societária, Contabilidade Fiscal e Atendimento a Usuários externos são realizadas de uma forma mais intensa na área de Controladoria, se comparadas aos bancos de capital nacional. No entanto, a função de Sistemas de Informações está mais presente nas áreas de Controladoria dos bancos de capital nacional que nos bancos de capital estrangeiro.

Quanto aos processos específicos, os dois grupos apresentam-se semelhantes, sendo a Controladoria responsável pelo Orçamento, Controle de Custos e Planejamento Tributário. Em relação ao processo de Controle de Riscos, nos bancos de capital estrangeiro, a Controladoria aparece em alguns casos como executora do processo, porém, em ambos os grupos, a Controladoria não é responsável ou coordena tal processo. 


\subsubsection{Estratificação 3: bancos privados e bancos estatais}

A terceira e última estratificação desta pesquisa teve como objetivo segregar os bancos pesquisados em dois grupos: os bancos privados e os bancos estatais. Os bancos estatais, por terem que atender regras específicas do governo e possuírem atribuições diferentes dos demais bancos, voltados mais para uma função social, possivelmente apresentam uma estrutura peculiar de suas áreas, o que os diferencia dos bancos privados. Esse motivo levou o pesquisador a realizar a estratificação sugerida nessa seção, separando os bancos pesquisados nesses dois grupos: bancos privados e bancos estatais.

O Quadro 8 apresenta, resumidamente, as características quanto à prática de Controladoria nos bancos privados.

Quadro 8 - Características dos bancos privados

\begin{tabular}{|c|c|}
\hline \multirow{2}{*}{$\begin{array}{l}\text { Descrição da Unidade } \\
\text { que exerce funções de } \\
\text { Controladoria }\end{array}$} & Em $63,16 \%$ dessas instituições, há uma área denominada Controladoria. \\
\hline & $\begin{array}{l}\text { Das } 36,84 \% \text { restantes, a área que exerce as funções de Controladoria é, } \\
\text { predominantemente, denominada Finanças, em mais de } 57 \% \text { dos casos. }\end{array}$ \\
\hline $\begin{array}{l}\text { Denominação do } \\
\text { Profissional } \\
\text { responsável pela } \\
\text { Controladoria }\end{array}$ & $\begin{array}{l}\text { Há uma diversidade entre os cargos do profissional responsável pela } \\
\text { Controladoria nessas instituições. As maiores frequências de denominações } \\
\text { são: CFO com } 21,05 \% \text { e Gerente de Controladoria e Controller, ambos com } \\
15,79 \% \text {. }\end{array}$ \\
\hline \multirow{6}{*}{$\begin{array}{l}\text { Funções exercidas pela } \\
\text { Controladoria }\end{array}$} & $\begin{array}{l}\text { Em } 93,68 \% \text { desses bancos, a função de Contabilidade Societária é uma função } \\
\text { típica da Controladoria. }\end{array}$ \\
\hline & $84,21 \%$ da função de Contabilidade Fiscal estão sob a Controladoria. \\
\hline & $\begin{array}{l}\text { Riscos e Controles Internos encontram-se, em sua maioria, na área de Riscos } \\
(39,10 \%) \text {, com destaque para a área de Controladoria }(30,83 \%) \text {. }\end{array}$ \\
\hline & $\begin{array}{l}\text { A função de Finanças está dividida entre as áreas de Controladoria, Tesouraria } \\
\text { e Outras áreas. }\end{array}$ \\
\hline & $\begin{array}{l}56,14 \% \text { das funções de Sistemas de Informações são desenvolvidas na } \\
\text { Controladoria. } \\
\text { 35,09\% são desenvolvidos na área de TI. O restante é desenvolvido em outras } \\
\text { áreas. }\end{array}$ \\
\hline & $\begin{array}{l}\text { A Controladoria é responsável, em } 80,26 \% \text { dessas instituições, pela função de } \\
\text { Atendimento aos Usuários Externos. }\end{array}$ \\
\hline $\begin{array}{l}\text { Participação da } \\
\text { Controladoria em } \\
\text { Processos Específicos }\end{array}$ & $\begin{array}{l}\text { Na maioria dessas instituições, o papel da Controladoria no Planejamento } \\
\text { Estratégico é de fornecer apoio/suporte informacional. A Controladoria não se } \\
\text { destaca como responsável ou coordenadora desse processo. } \\
52,63 \% \text { desses bancos apontaram a Controladoria como responsável pelo } \\
\text { Orçamento, destacando, também, que, em } 44,74 \% \text { dos casos, a Controladoria é } \\
\text { a executora desse processo. }\end{array}$ \\
\hline
\end{tabular}


continuação

\begin{tabular}{|c|l|}
\hline \multirow{2}{*}{$\begin{array}{c}\text { Participação da } \\
\text { Controladoria em } \\
\text { Processos Específicos }\end{array}$} & $\begin{array}{l}\text { No processo de análises do ambiente externo, interno e viabilidade de projetos } \\
\text { e produtos, a Controladoria tem, em grande parte, participação, apenas, } \\
\text { fornecendo apoio/suporte informacional. } \\
\text { Aessa mesma forma, a Controladoria é responsável pelo processo de } \\
\text { Avaliação de Desempenhos (gestor e produtos), não se apresentando } \\
\text { informacional. }\end{array}$ \\
\cline { 2 - 2 } & $\begin{array}{l}\text { Nos processos de Controle de Custos e Planejamento tributário, a } \\
\text { Controladoria destaca-se como responsável e executora desses processos. } \\
\text { Quanto ao Controle de Riscos, a Controladoria não é responsável e não } \\
\text { organiza esse processo. Destaque-se que ela, apenas, realiza suas tarefas desse } \\
\text { processo, assim como as demais áreas do banco. }\end{array}$ \\
\hline
\end{tabular}

No Gráfico 30, estão ilustradas as funções gerais da Controladoria e qual a área responsável por exercê-las nesse grupo denominado bancos privados, de acordo com o Quadro 8.

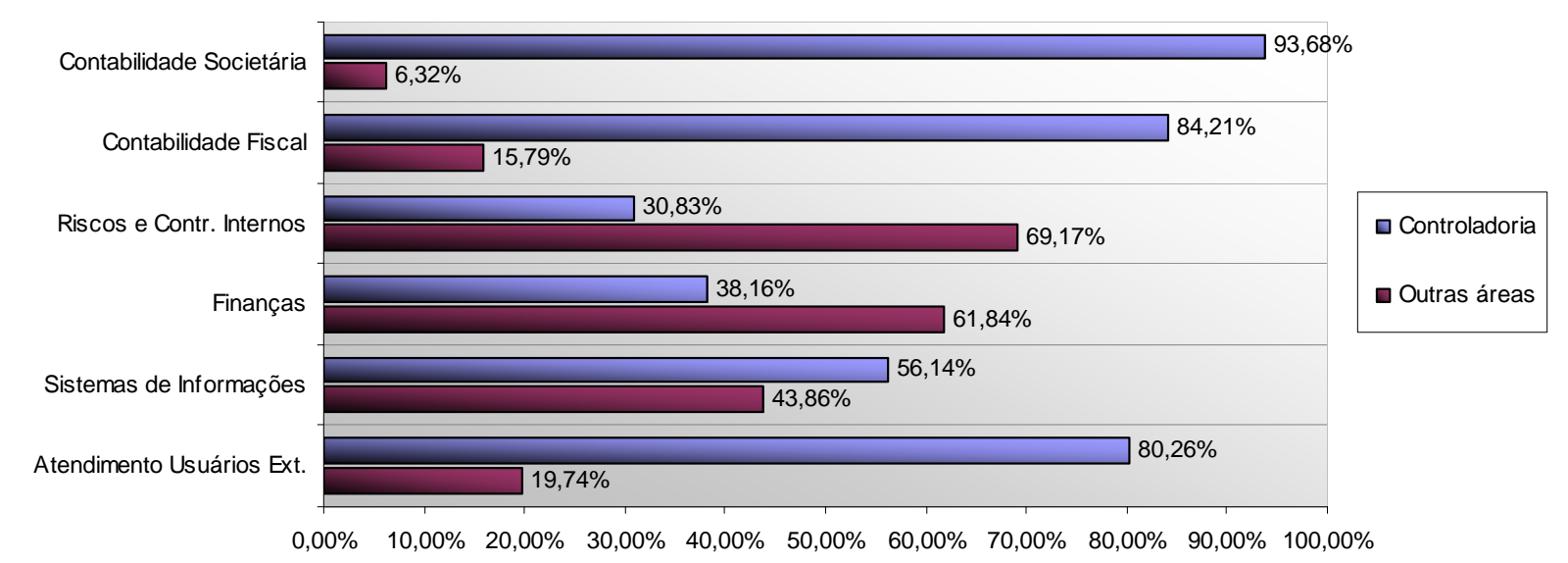

Gráfico 30 - Funções gerais da controladoria nos bancos privados

Veja-se, no Gráfico 30, que as funções Contabilidade Societária, Contabilidade Fiscal e Atendimento a Usuários Externos são funções tipicamente encontradas na área de Controladoria desses bancos privados.

No Quadro 9, a seguir, estão as características dos bancos estatais, conforme estratificação realizada nessa seção. 
Quadro 9 - Características dos bancos estatais

\begin{tabular}{|c|c|}
\hline \multirow[b]{2}{*}{$\begin{array}{l}\text { Descrição da Unidade } \\
\text { que exerce funções de } \\
\text { Controladoria }\end{array}$} & $83,33 \%$ desses bancos possuem uma área denominada Controladoria. \\
\hline & $\begin{array}{l}\text { Os que não possuem a nomeação Controladoria, ou seja, } 16,67 \% \text { denominam } \\
\text { a área que exerce funções de Controladoria como Vice-Presidência de } \\
\text { Controles e Riscos. }\end{array}$ \\
\hline $\begin{array}{l}\text { Denominação do } \\
\text { Profissional } \\
\text { responsável pela } \\
\text { Controladoria }\end{array}$ & $\begin{array}{l}\text { Em } 50 \% \text { dos bancos estatais, o profissional responsável pela Controladoria é o } \\
\text { Gerente de Controladoria. Os demais possuem denominações como } \\
\text { Controller, Diretor de Controladoria e Vice-Presidente, com } 16,67 \% \text { cada um. }\end{array}$ \\
\hline \multirow{6}{*}{$\begin{array}{l}\text { Funções exercidas pela } \\
\text { Controladoria }\end{array}$} & $\begin{array}{l}\text { Apenas } 16,67 \% \text { dos bancos possuem a função Contabilidade Societária na } \\
\text { Controladoria. O restante encontra-se em outras áreas, com destaque para a } \\
\text { área denominada Contabilidade com } 66,67 \% \text {. }\end{array}$ \\
\hline & $\begin{array}{l}\text { Da mesma forma, a função Contabilidade Fiscal aparece sob responsabilidade } \\
\text { da Controladoria em apenas } 16,67 \% \text {, destacando-se a área de Contabilidade } \\
\text { com } 50 \% \text { da função. }\end{array}$ \\
\hline & $\begin{array}{l}35,71 \% \text { da função de Riscos e Controles internos estão sob a Controladoria, } \\
\text { sendo que } 40,48 \% \text { está sob a área de Riscos. }\end{array}$ \\
\hline & $\begin{array}{l}\text { A função de Finanças divide-se entre as áreas de Controladoria, Tesouraria e } \\
\text { Financeira. }\end{array}$ \\
\hline & $\begin{array}{l}\text { Já a função Sistemas de Informações, está presente na Controladoria em } \\
88,89 \% \text { dessas instituições. }\end{array}$ \\
\hline & $\begin{array}{l}\text { A função de Atendimento aos Usuários Externos apresenta-se em } 45,83 \% \text { sob } \\
\text { a responsabilidade da Controladoria, sendo o restante diluído em diversas } \\
\text { áreas. }\end{array}$ \\
\hline \multirow{3}{*}{$\begin{array}{l}\text { Participação da } \\
\text { Controladoria em } \\
\text { Processos Específicos }\end{array}$} & $\begin{array}{l}\text { Na maioria dessas instituições o papel da Controladoria no Planejamento } \\
\text { Estratégico é de fornecer apoio/suporte informacional com } 75 \% \text {. A } \\
\text { Controladoria não se destaca como responsável ou coordenadora desse } \\
\text { processo. } \\
\text { Quanto ao processo de Orçamento, } 83,33 \% \text { destacam a Controladoria como } \\
\text { responsável pelo processo. }\end{array}$ \\
\hline & $\begin{array}{l}\text { No processo de análises do ambiente externo, interno e viabilidade de projetos } \\
\text { e produtos, a Controladoria tem, em grande parte, participação, apenas, } \\
\text { fornecendo apoio/suporte informacional. } \\
\text { Na Avaliação de Desempenho, a Controladoria destaca-se, sendo, na maioria } \\
\text { desses bancos, responsável e corresponsável pelo processo. }\end{array}$ \\
\hline & $\begin{array}{l}\text { Nos processos de Controle de Custos, a Controladoria é apontada em mais de } \\
80 \% \text { dessas instituições como responsável pelo processo. } \\
\text { Já no Planejamento tributário, a Controladoria, apenas, realiza suas tarefas } \\
\text { desse processo, assim como as demais áreas do banco. } \\
\text { Quanto ao Controle de Riscos, a Controladoria não é responsável e não } \\
\text { organiza esse processo. }\end{array}$ \\
\hline
\end{tabular}

No Gráfico 31, a seguir, estão consolidadas as funções gerais da Controladoria para os bancos estatais, com o percentual da área responsável da função, dividido entre área de Controladoria e demais áreas. 


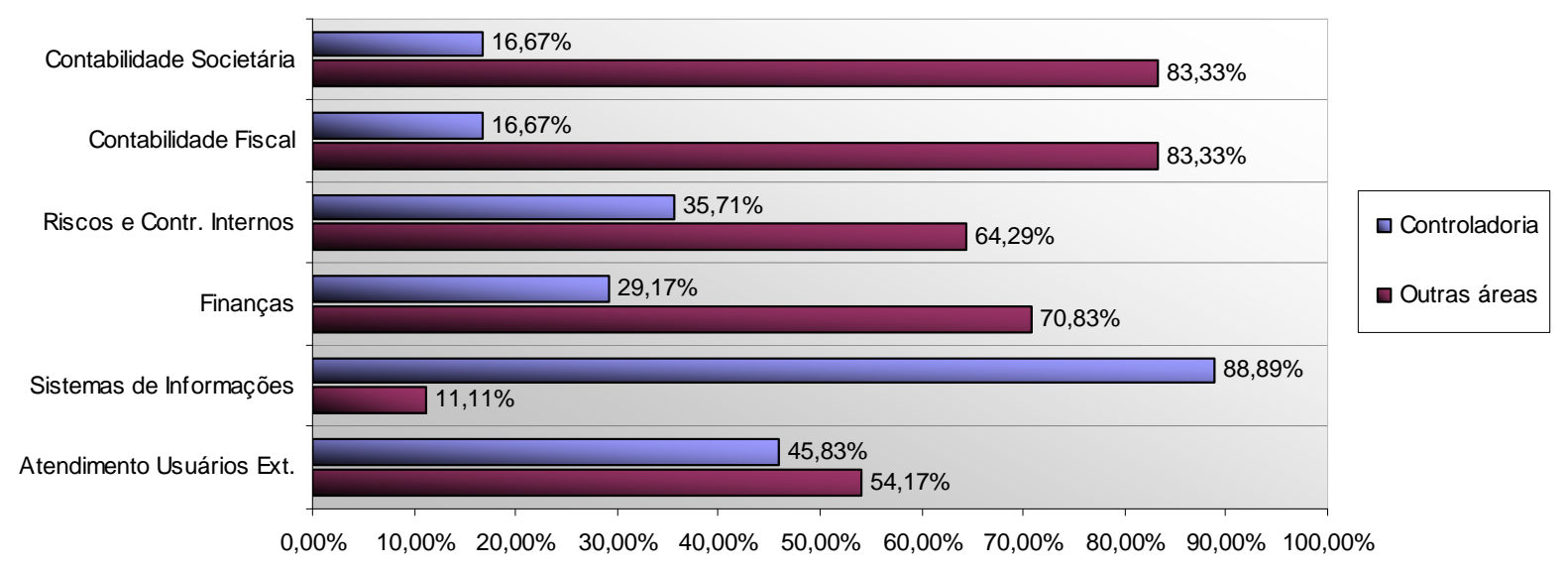

Gráfico 31 - Funções gerais da controladoria nos bancos estatais

Observe-se, no Gráfico 31, que as funções de Contabilidade Societária, Contabilidade Fiscal e Atendimento a Usuários Externos, predominantemente típicas da área de Controladoria nos bancos privados apresentados anteriormente, nos bancos estatais essas funções estão sob a responsabilidade de outras áreas, não sendo funções típicas da área de Controladoria. Percebese que a função mais típica da Controladoria nos bancos estatais é a de Sistemas de Informações.

Verificando-se os processos específicos dos dois grupos, entende-se que a Controladoria nos bancos estatais tem sob sua responsabilidade o processo de Orçamento. Dessa forma, pode-se entender que o processo de elaboração e controle do Orçamento é uma tarefa típica da área de Controladoria nos bancos estatais, enquanto nos bancos privados, esse processo não representa um percentual tão elevado de responsabilidade. Outro ponto de destaque na área de Controladoria dos bancos estatais é o processo de Controle de Custos, o qual foi elencado por mais de $80 \%$ das instituições como a Controladoria sendo responsável pelo processo. Esse percentual, também, não é tão representativo nas instituições privadas.

Outra divergência encontrada nos processos específicos é o Planejamento Tributário. Nos bancos privados, a Controladoria é, em maior parte, responsável por esse processo, enquanto, nos bancos estatais, a Controladoria, apenas, realiza suas tarefas desse processo, assim como as demais áreas. Já no que tange ao Controle dos Riscos, tanto nos bancos privados quanto nos estatais, a Controladoria não é responsável ou coordenadora desse processo. 



\section{CONSIDERAÇÕES FINAIS}

A melhoria de processos e práticas de gestão tornou-se essencial aos bancos que operam no Brasil, em presença da rápida evolução das atividades econômicas e do mercado de crédito. Diante disso, a Controlaria, bem como as informações por ela disponibilizadas, ganha mais espaço e importância dentro das instituições financeiras. Esse novo enfoque pode ser percebido, inclusive, nos estudos acadêmicos que passaram a se dedicar em temos relativos a modelos, funções e práticas da Controladoria nessas entidades.

Nesse sentido, este trabalho teve como objetivo geral verificar se, e em que medida, as práticas de Controladoria dos maiores bancos que operam no Brasil, refletem-se a uma Estrutura Conceitual Básica de Controladoria. Também, foram elencados objetivos específicos, tais como: (i) revisar os conceitos propostos por Borinelli (2006) para uma ECBC; (ii) complementar a ECBC com foco em instituições financeiras; (iii) investigar se ocorre uma aplicação da teoria da Controladoria, na prática, nos maiores bancos que operam no Brasil e (iv) verificar a aderência dessas instituições à ECBC.

Com a finalidade de cumprir esses objetivos propostos, apresentou-se, no Capítulo 2, uma revisão da ECBC proposta por Borinelli (2006), com uma complementação das funções e atribuições da Controladoria voltadas para instituições financeiras, de acordo com literatura específica sobre esse assunto. No Capítulo 4, foram realizadas análises sobre a aplicação da teoria na prática nos bancos pesquisados, bem como uma análise da aderência dessas práticas de Controladoria à ECBC. Ainda nesse capítulo, foi analisada a forma em que se reflete a ECBC nos maiores bancos que operam no Brasil. Sendo assim, pode-se dizer que essas abordagens contemplam evidencias do cumprimento dos objetivos desta pesquisa.

A questão de pesquisa definida procurou, à luz de uma Estrutura Conceitual Básica de Controladoria, entender quais os elementos que refletem a prática dos maiores bancos que operam no Brasil. Além disso, foram propostas questões expandidas, que interrogavam sobre: (i) quais os elementos que deveriam integrar uma ECBC para contemplar instituições financeiras; (ii) quais as práticas de Controladoria nos maiores bancos que operam no Brasil e (iii) qual o nível de aderência dos elementos da ECBC nessas instituições. 
Para responder à primeira questão expandida, foi realizada uma revisão da literatura sobre Controladoria em instituições financeiras. Procurou-se entender quais as funções e atribuições específicas para essas entidades, que poderiam não estar sendo contempladas pela ECBC, a qual tinha um aspecto muito genérico, sem focar algum segmento específico. Com isso, no Capítulo 2 deste trabalho, foi apresentado um tópico com uma revisão da literatura que aborda especificamente funções e atribuições da Controladoria em bancos, como forma de complementar a ECBC, contemplando aspectos para essas instituições.

A segunda e a terceira questão de pesquisa expandida, bem como a questão geral de pesquisa proposta, foram respondidas por uma pesquisa empírica, mediante entrevistas e questionários, realizada com 25 dos 50 maiores bancos que operam no Brasil. Os dados obtidos nos bancos respondentes foram tratados, analisados à luz dos elementos que contemplam a ECBC e apresentados na forma de resultados no Capítulo 4. Esses foram divididos entre informações gerais, perfil das instituições pesquisadas, análise e interpretação das práticas de Controladoria e, por fim, uma análise comparativa dos resultados, com estratificações dos bancos respondentes.

Com base na questão de pesquisa formulada, este trabalho seguiu uma hipótese de pesquisa, estabelecida como uma resposta ao problema que foi investigado. Tal hipótese anunciou que: as práticas de Controladoria dos maiores bancos que operam no Brasil refletem os elementos que integram uma Estrutura Conceitual Básica de Controladoria.

A partir dos dados obtidos, observa-se que, quanto à existência de uma unidade denominada Controladoria, comprovou-se que, em $68 \%$ das instituições pesquisadas, havia uma unidade com essa denominação. As demais instituições apresentam outra denominação para a área que exerce as funções e atribuições de Controladoria. Além disso, em 92\% desses bancos, a Controladoria é centralizada em um único órgão. Outra característica encontrada é que o cargo do responsável pela unidade organizacional de Controladoria, seja essa denominada Controladoria ou não, tem o status de Diretor em 32\%, Gerente em 24\%, CFO e Controller em $16 \%$ dos bancos pesquisados, entre outros cargos com menor frequência.

Com relação às funções e atribuições da Controladoria, verificou-se que as funções de Contabilidade Societária, Contabilidade Fiscal, Gestão das Informações e Atendimento a 
Usuários Externos, são funções típicas da área de Controladoria nas instituições financeiras pesquisadas, aderindo às especificações feitas pela ECBC.

Já as funções de Riscos, Controles Internos e Finanças não foram apontadas pelos bancos pesquisados como funções desempenhadas pela área de Controladoria. A função de Riscos e Controles Internos é, em sua maioria, realizada na área denominada Riscos, destacando-se, também, as áreas de Auditoria Interna, Controles Internos e Compliance. Logo a função de Finanças se divide entre a área de Controladoria e a área denominada Tesouraria. Essas funções são elementos da ECBC, sendo que a função de Riscos e Controles Internos é, densamente, indicada na revisão da literatura sobre funções de Controladoria para bancos. Todavia, o que se percebe é que essas duas funções, na prática dos bancos pesquisados, não estão aderentes à ECBC.

Além dessas funções gerais da Controladoria, a ECBC, complementada com a revisão de funções e atribuições da Controladoria para bancos, relata o papel da Controladoria como responsável ou coordenadora de alguns processos específicos. Verificou-se que, para os processos específicos de Orçamento, Mensuração, Análise e Controle de Custos, bem como no Planejamento Tributário, a Controladoria é considerada como a área responsável, conforme respostas obtidas nos bancos participantes da pesquisa. A prática dos bancos pesquisados, nesses processos específicos, está aderente ao que se encontra na ECBC.

Entretanto, para os processos de Planejamento Estratégico, Análises de Ambientes e Viabilidades, Avaliação de Desempenho e Controle de Riscos, a Controladoria não é considerada como responsável ou coordenadora desses processos e, em muitos casos, apenas, fornece apoio/suporte informacional. Dessa forma, pontualmente, para esses processos, conclui-se que a prática dos bancos pesquisados não está aderente à ECBC.

Não obstante, optou-se, ainda, por estratificar os dados obtidos entre diferentes grupos de instituições, o que permitiu realizar uma comparação da prática de Controladoria entre os grupos distintos. A primeira estratificação separou os dados entre os sete maiores bancos e demais bancos pesquisados. Outra estratificação realizada foi entre bancos de capital nacional e bancos de capital estrangeiro. Por fim, a última estratificação foi a separação entre bancos privados e bancos estatais. O que se concluiu foi que a prática de Controladoria de alguns grupos parece ser mais aderente aos elementos que integram a ECBC, do que em outros 
grupos. Dentre esses grupos, destacam-se: os sete maiores bancos pesquisados, os bancos de capital estrangeiro e os bancos privados. Todavia, em nenhum dos grupos os elementos da ECBC refletem, completamente, a prática de Controladoria dos bancos.

Diante dos resultados a que se chegou neste trabalho, e diante da complexidade dos aspectos da Controladoria, deduz-se que futuras pesquisas podem contribuir de muitas formas para analisar e fazer novas descobertas, no que tange à prática de Controladoria nas instituições financeiras. Perante isso, é possível relacionar sugestões para o desenvolvimento de pesquisas futuras, como: (i) ampliar o número de bancos, separando-os por foco de atividade e investigando a prática da Controladoria em bancos de porte menor; (ii) investigar a diferença da prática de Controladoria entre empresas que não sejam instituições financeiras, com os bancos desta pesquisa e (iii) investigar o motivo de as funções, apontadas nesta pesquisa, não aderirem aos elementos da ECBC em instituições financeiras, principalmente no que tange à função de Riscos e Controles Internos.

Por fim, conclui-se que, tanto os objetivos específicos elencados, quanto o objetivo geral da pesquisa, foram plenamente satisfeitos e alcançados. Entretanto, os achados deste trabalho permitem confirmar, parcialmente, a hipótese enunciada, visto que nem todos os elementos que integram a ECBC, juntamente com a complementação de funções e atribuições da Controladoria voltadas para bancos, estão refletidos na prática dessas instituições. 


\section{REFERÊNCIAS}

AHRENS, Thomas; CHAPMAN, Christopher S.. Management accounting as practice. Accounting, Organizations and Society, n. 32, p. 1-27, 2007.

ANDREZO, Andrea F.; LIMA, Iran Siqueira. Mercado financeiro: Aspectos Conceituais e Históricos. 3. ed. São Paulo: Atlas, 2007.

ARIENTI, Patrícia F. F.. Reestruturação e consolidação do sistema bancário privado brasileiro. Ensaios FEE, n. 2, p. 577-600, 10/2007.

ASSAF NETO, Alexandre. Estrutura e análise de balanços: um enfoque econômicofinanceiro. 8. ed. São Paulo: Atlas, 2007.

. Mercado financeiro. 7. ed. São Paulo: Atlas, 2006.

BANCO CENTRAL DO BRASIL. Resolução n. 2.099, 26 de agosto de 1994. Brasília, DF, 1994.

. Resolução n. 1.524, de 21 de setembro de 1988. Brasília, DF, 1988.

Resolução n. 3.040, de 28 de outubro de 2002. Brasília, DF, 2002.

Resolução n. 3.380, de 29 de junho de 2006. Brasília, DF, 2006.

BATISTELLA, Flávio Donizete. Uma análise do valor gerado para acionistas de bancos brasileiros que fizeram aquisições entre 1995 e 2004. São Paulo, 2005. Dissertação (Mestrado em Ciências Contábeis) - Programa de Pós-Graduação em Ciências Contábeis, Departamento de Contabilidade e Atuária, Faculdade de Economia, Administração e Contabilidade da Universidade de São Paulo.

BENNETT, Barbara. Off balance sheet risk in banking: the case of standby letters of credit. Federal Reserve Bank of San Francisco - Economic Review, n. 1, p. 19-29, 1986.

BOLLERSLEV, T. et al. ARCH modeling in finance: a review of theory and empirical evidence. Journal of Econometrics, v. 52, p. 5-59, 1992.

BORINELLI, Márcio Luiz. Estrutura conceitual básica de controladoria: sistematização à luz da teoria e da práxis. São Paulo, 2006. Tese (Doutorado em Ciências Contábeis) Programa de Pós-Graduação em Ciências Contábeis, Departamento de Contabilidade e Atuária, Faculdade de Economia, Administração e Contabilidade da Universidade de São Paulo. 
BRANDÃO, Marcelo Moll et al.. Marketing e performance no setor bancário brasileiro. In: CONGRESSO USP DE CONTROLADORIA E CONTABILIDADE, 5., 2005, São Paulo. Anais... São Paulo: USP, 2005.

BRASIL. Lei n. 4.595, 31 de dezembro de 1964. Presidência da República. Brasília, DF, 1964.

BREALEY, Richard A. et al.. Principles of corporate finance. 9. ed. Nova Iorque: McGrawHill, 2008.

BRITO, Osias Santana de. Contribuição ao estudo de modelo de controladoria de riscoretorno em bancos de atacado. São Paulo, 2000. Tese (Doutorado em Ciências Contábeis) Programa de Pós-Graduação em Ciências Contábeis, Departamento de Contabilidade e Atuária, Faculdade de Economia, Administração e Contabilidade da Universidade de São Paulo.

CAPELLETTO, Lucio Rodrigues; CORRAR, Luiz João. Índices de risco sistêmico para o setor bancário. Revista Contabilidade \& Finanças - USP, n. 47, p. 6-18, 05-08/2008.

CARVALHO, Marcelino Freitas de. Uma contribuição ao estudo da controladoria em instituições financeiras organizadas sob a forma de banco múltiplo. São Paulo, 1995. Dissertação (Mestrado em Ciências Contábeis) - Programa de Pós-Graduação em Ciências Contábeis, Departamento de Contabilidade e Atuária, Faculdade de Economia, Administração e Contabilidade da Universidade de São Paulo.

Silvio Aparecido de. Desenvolvimento de Novas Técnicas para a Gestão Bancária no Brasil. São Paulo, 1993. Tese (Doutorado em Ciências Contábeis) - Programa de PósGraduação em Ciências Contábeis, Departamento de Contabilidade e Atuária, Faculdade de Economia, Administração e Contabilidade da Universidade de São Paulo.

CASELLA, Bruna Maria Barbosa Xavier; BISPO, Jorge de Souza. Um estudo do impacto do acordo da Basiléia I no resultado dos bancos no Brasil. In: ENCONTRO DA ASSOCIAÇÃO NACIONAL DE PÓS-GRADUAÇÃO E PESQUISA EM ADMINISTRAÇÃO - EnANPAD, 31., 2007, Rio de Janeiro. Anais... Rio de Janeiro: ANPAD, 2007.

CATELLI, Armando (Coord.). Controladoria: uma abordagem da gestão econômica GECON. 2. ed. São Paulo: Atlas, 2001.

et al. Avaliação de resultados e desempenhos em instituições financeiras. In: Controladoria: uma abordagem da gestão econômica - GECON. Armando Catelli (Coord.). São Paulo: Atlas, 2001.

CHAGAS, José Ferreira. O exercício da controladoria em instituições bancárias com atuação no Brasil. São Paulo, 2000. Dissertação (Mestrado em Ciências Contábeis) Programa de Pós-Graduação em Ciências Contábeis, Departamento de Contabilidade e 
Atuária, Faculdade de Economia, Administração e Contabilidade da Universidade de São Paulo.

CHEN, Yeh-Ning. Banking panics: the role of the first-come, first-served rule and information externalities. Journal of Political Economy, v. 107, n. 5, p. 946-968, 1999.

CORNELL, B.; SHAPIRO, A. C.. Managing foreign exchange risks. Midland Corporate Finance Journal, Midland, TX, p.16-31, 1983.

DAMODARAN, Aswath. Applied corporate finance: a user's manual. Nova Iorque: John Wiley \& Sons, Inc, 1999.

DEMO, Pedro. Metodologia do conhecimento científico. São Paulo: Atlas, 2000.

DE PAULA, L. F. R.; MARQUES, Maria B. L.. Tendência recentes da consolidação bancária no mundo e no Brasil. In: ENCONTRO NACIONAL DE ECONOMIA POLÍTICA, 9., 2004, Uberlândia. Anais... Uberlândia: Sociedade Brasileira de Economia Política, 2004.

DOORNIK, Bernardus F. N. V. et al.. Transparência das demonstrações contábeis no Brasil após o acordo de Basiléia 2: um estudo temporal dos 10 maiores bancos do país. In: ENCONTRO DA ASSOCIAÇÃO NACIONAL DE PÓS-GRADUAÇÃO E PESQUISA EM ADMINISTRAÇÃO - EnANPAD, 31, 2007, Rio de Janeiro. Anais... Rio de Janeiro: ANPAD, 2007.

ESPEJO, Márcia M. S. B.. Perfil dos atributos do sistema orçamentário sob a perspectiva contingencial: uma abordagem multivariada. São Paulo, 2008. Tese (Doutorado em Ciências Contábeis) - Programa de Pós-Graduação em Ciências Contábeis, Departamento de Contabilidade e Atuária, Faculdade de Economia, Administração e Contabilidade da Universidade de São Paulo.

EXAME. São Paulo: Abril, Melhores e Maiores, 04-06/2008.

FARIAS, Cláudio Gondim Bezerra. A controladoria no contexto do sistema de gestão econômica (Gecon) - uma abordagem para instituições financeiras. São Paulo, 1998. Dissertação (Mestrado em Ciências Contábeis) - Programa de Pós-Graduação em Ciências Contábeis, Departamento de Contabilidade e Atuária, Faculdade de Economia, Administração e Contabilidade da Universidade de São Paulo.

FEBRABAN. Relatório social FEBRABAN, 2007. Disponível em: <http://www.febraban. org.br>. Acesso em: 15/10/2008.

FERREIRA, Caio Fonseca; FARINA, Elizabeth M. M. Q.. Concorrência e performance do setor bancário em um mercado heterogêneo. Revista EconomiA, Selecta, v. 6, n. 3, p. 157$189,12 / 2005$. 
FORTUNA, Eduardo. Mercado financeiro: produtos e serviços. 16. ed. Rio de Janeiro: Qualitymar, 2005.

FREZATTI, Fábio. Orçamento empresarial: planejamento e controle gerencial. São Paulo: Atlas, 2006.

GIL, Antônio Carlos. Como elaborar projetos de pesquisa. 4. ed. São Paulo: Atlas, 2002.

GITMAN, L. J.. Princípios de administração financeira. 10. ed. São Paulo: Addison Wesley, 2004.

GLAUM, Martin. Strategic management of exchange rate risks. Long Range Planning, v. 23, n. 4, p. 65-72, 1990.

GOULART, André Moura Cintra. Evidenciação contábil do risco de mercado por instituições financeiras no Brasil. São Paulo, 2003. Dissertação (Mestrado em Ciências Contábeis) - Programa de Pós-Graduação em Ciências Contábeis, Departamento de Contabilidade e Atuária, Faculdade de Economia, Administração e Contabilidade da Universidade de São Paulo.

GRANDE, Jefferson F.; BEUREN, Ilse Maria. Abordagens da controladoria em livros publicados no Brasil. Revista de Informação Contábil, v. 2, n. 1, p. 40-55, 01-03/2008.

GUERREIRO, Reinaldo et al.. A controladoria sob o enfoque gecon - gestão econômica: a experiência da Caixa Econômica Federal do Brasil. Revista de Contabilidade CRC-SP, p. 45-51, 04/1997.

HIRTLE, Beverly J.; STIROH, Kevin J.. The return to retail and the performance of US Banks. Journal of Banking \& Finance, v. 31, p. 1101-1133, 2006.

JORION, Philippe. Value at risk: a nova fonte de referência para o controle do risco de mercado. São Paulo: BMF Brasil, 1998.

KANITZ, Stephen Charles. Controladoria: teoria e estudo de casos. São Paulo: Pioneira, 1976.

KERLINGER, Fred Nichols. Metodologia da pesquisa em ciências sociais: um tratamento conceitual. São Paulo: Edusp, 1980.

LIMA, Iran Siqueira et al. (Coord.). Curso de mercado financeiro: tópicos especiais. São Paulo: Atlas, 2006.

; LOPES, Alexandro Broedel. Contabilidade e controle de operações com derivativos. São Paulo: Pioneira, 1999. 
MACEDO, Marcelo Álvaro da Silva et al.. Desempenho organizacional no setor bancário brasileiro: uma aplicação da análise envoltória de dados. In: ENCONTRO DA ASSOCIAÇÃO NACIONAL DE PÓS-GRADUAÇÃO E PESQUISA EM ADMINISTRAÇÃO - EnANPAD, 29., 2005, Brasília. Anais... Brasília: ANPAD, 2005.

MARCONI, Marina de Andrade; LAKATOS, Eva Maria. Fundamentos de metodologia científica. 6. ed. São Paulo: Atlas, 2005

MARTIN, Nilton Cano. Da contabilidade à controladoria: a evolução necessária. Revista Contabilidade \& Finanças - USP, n. 28, p. 7-28, 01-04/2002.

MARTINS, Gilberto de Andrade. Manual para elaboração de monografias e dissertações. 2. ed. São Paulo: Atlas, 1994.

; THEÓPHILO, Carlos Renato. Metodologia da investigação científica para ciências sociais aplicadas. São Paulo: Atlas, 2007.

MATARAZZO, Dante Carmine. Análise financeira de balanços: abordagem básica e gerencial. 6. ed. São Paulo: Atlas, 2003.

MENDONÇA, A. R. R.. O Acordo da Basiléia de 2004: uma revisão em direção às práticas de mercado. Revista Economia Política Internacional: Análise Estratégica, n. 2, p. 27-37, 07-09/2004.

MERLOTTO, Juliano et al. . A exposição ao risco de câmbio e o valor das empresas: uma análise no mercado de ações brasileiro no período de 1999 a 2003. Revista de Administração da USP - Eletrônica, v 1, n. 1, 2008.

MOSIMANN, Clara Pellegrinello; FISCH, Silvio. Controladoria: seu papel na administração de empresas. São Paulo: Atlas, 1999.

NAKAGAWA, Masayuki. ABC: custeio baseado em atividades. São Paulo: Atlas, 1994.

Introdução à controladoria. São Paulo: Atlas, 1993.

NASCIMENTO, Auster Moreira; BIANCHI Márcia. Um estudo sobre o papel da controladoria no processo de redução de conflitos de agência e de governança corporativa. In: CONGRESSO USP DE CONTROLADORIA E CONTABILIDADE, 5., 2005, São Paulo. Anais... São Paulo: USP, 2005.

, A.; REGINATO, L.. Controladoria: um enfoque na eficácia organizacional. São Paulo: Atlas, 2007. 
NEVES JR., Idalberto José das et al.. Eficiência operacional: uma análise exploratória dos 50 maiores bancos brasileiros pelo ranking BACEN. In: CONGRESSO USP DE CONTROLADORIA E CONTABILIDADE, 7., 2007, São Paulo. Anais... São Paulo: USP, 2007.

OLIVEIRA, Djalma de Pinho Rebouças de. Sistemas, organização e métodos: uma abordagem gerencial. 11 ed. São Paulo: Atlas, 2000.

PARISI, Cláudio. Ensaio sobre o comportamento organizacional. In: Controladoria: uma abordagem da gestão econômica - GECON. Armando Catelli (Coord.). São Paulo: Atlas, 2001.

PI, Lynn; TIMME, Stephen G.. Corporate control and bank efficiency. Journal of Banking and Finance, p. 515-530, 1993.

PINHEIRO, Fábio Araújo. Uma contribuição ao estudo da atuação da controladoria na avaliação de resultados e desempenhos em instituições financeiras de desenvolvimento. São Paulo, 2000. Dissertação (Mestrado em Ciências Contábeis) - Programa de PósGraduação em Ciências Contábeis, Departamento de Contabilidade e Atuária, Faculdade de Economia, Administração e Contabilidade da Universidade de São Paulo.

ROSS, Stephen A. et al.. Princípios de administração financeira. 2. ed. São Paulo: Atlas, 2000 .

SALOMON, Délcio Vieira. Como fazer uma monografia. 9. ed. São Paulo: Martins Fontes, 1999.

SANTOS, Lílian Regina dos. A governança empresarial e a emergência de um novo modelo de controladoria. São Paulo, 2004. Dissertação (Mestrado em Ciências Contábeis) Programa de Pós-Graduação em Ciências Contábeis, Departamento de Contabilidade e Atuária, Faculdade de Economia, Administração e Contabilidade da Universidade de São Paulo.

Sérgio Cipriano dos. Risco legal nas instituições financeiras: o impacto da jurisprudência no crédito bancário. São Paulo, 2007. Dissertação (Mestrado em Administração) - Programa de Pós-Graduação em Administração, Departamento de Administração, Faculdade de Economia, Administração e Contabilidade da Universidade de São Paulo.

SAUNDERS, Anthony. Administração de instituições financeiras. São Paulo: Atlas, 2000.

SCHNORRENBERGER, Darci et al.. Uma análise das funções da controladoria: um estudo comparativo dos Estados Unidos, Alemanha e Brasil. In: CONGRESSO BRASILEIRO DE CUSTOS, 15., 2007. João Pessoa. Anais... João Pessoa: Associação Brasileira de Custos, 2007. 
SCHWARZE, Felix et al.. Drivers of and barriers to management accounting change. AAA 2008 MAS Meeting Paper, 2008.

TABAK, Benjamin Miranda et al. Eficiência bancária: o valor intrínseco na função de produção. Revista de Administração da USP, v. 40, n. 4, 2005.

TRAPP, Adriana C. Garcia. Estudo da avaliação e gerenciamento do risco operacional de instituições financeiras no Brasil: análise de caso de uma instituição financeira de grande porte. São Paulo, 2004. Dissertação (Mestrado em Ciências Contábeis) - Programa de PósGraduação em Ciências Contábeis, Departamento de Contabilidade e Atuária, Faculdade de Economia, Administração e Contabilidade da Universidade de São Paulo.

VERRONE, Marco Antonio Guimarães. Basiléia II no Brasil: uma reflexão com foco na regulação bancária para risco de crédito - Resolução CMN 2.682/99. São Paulo, 2007. Dissertação (Mestrado em Administração) - Programa de Pós-Graduação em Administração, Departamento de Administração, Faculdade de Economia, Administração e Contabilidade da Universidade de São Paulo.

VIEIRA, Rui; HOSKIN, Keith. Management accounting practices and discourses change: the role and use of management accounting systems. FEUNL Working Papern, n. 481, 2005.

XAVIER, Paulo Henrique Moura. Transparência das demonstrações contábeis dos bancos no Brasil: estudo de caso sob a perspectiva do acordo "Basiléia 2". São Paulo, 2003. Dissertação (Mestrado em Ciências Contábeis) - Programa de Pós-Graduação em Ciências Contábeis, Departamento de Contabilidade e Atuária, Faculdade de Economia, Administração e Contabilidade da Universidade de São Paulo. 



\section{APÊNDICES}

APÊNDICE 1 - CARTA DE APRESENTAÇÃO

APÊNDICE 2 - QUESTIONÁRIO 



\title{
APÊNDICE 1 - CARTA DE APRESENTAÇÃo
}

\author{
Universidade de São Paulo \\ Faculdade de Economia, Administração e Contabilidade \\ Departamento de Contabilidade e Atuária \\ Programa de Pós-Graduação em Controladoria e Contabilidade
}

\section{Carta de Apresentação}

São Paulo/SP, de de 2008.

Ilustríssimo Sr.

Na qualidade de Professor Doutor do Departamento de Contabilidade e Atuária da Faculdade de Economia, Administração e Contabilidade (FEA) da Universidade de São Paulo (USP), Diretor Presidente da Fundação Instituto de Pesquisas Contábeis Atuariais e Financeiras (FIPECAFI), membro de conselhos de administração e fiscal de diversas empresas e tendo exercido os cargos de Diretor das Áreas de Mercado de Capitais e de Fiscalização do Banco Central do Brasil, Secretário Executivo de Controle de Empresas Estatais - SEST, Secretário Executivo do Conselho Interministerial de Salários das Empresas Estatais - CISE e Diretor Econômico-Financeiro da Telebrás, tenho a grata satisfação de apresentar a V.Sa. o Sr. BLEISE RAFAEL DA CRUZ, aluno de mestrado do Programa de Pós-Graduação em Controladoria e Contabilidade desta Universidade, da linha de pesquisa acadêmica "Mercado Financeiro, de Crédito e de Capitais", cujo trabalho de pesquisa se encontra sob minha orientação.

A dissertação de mestrado do referido aluno consiste em investigar as práticas de Controladoria dos maiores bancos que operam no Brasil. Ressaltamos que não serão levantados números contábeis, mas tão somente informações sobre como são desenvolvidas as funções de Controladoria nessas instituições. Para o levantamento dos dados necessários à pesquisa é que solicito encarecidamente a colaboração de V.Sa., concedendo uma entrevista ao mestrando, a qual tem duração máxima estimada de aproximadamente 60 (sessenta) minutos.

Saliento o compromisso ético assumido pelo pesquisador em que os dados obtidos serão utilizados exclusivamente para os fins mencionados, passando por um tratamento estatístico, e sendo garantido o sigilo necessário.

Antecipadamente agradeço a colaboração de V.Sa.

Prof. Dr. Iran Siqueira Lima

Orientador 



\section{APÊNDICE 2 - QUESTIONÁRIO}

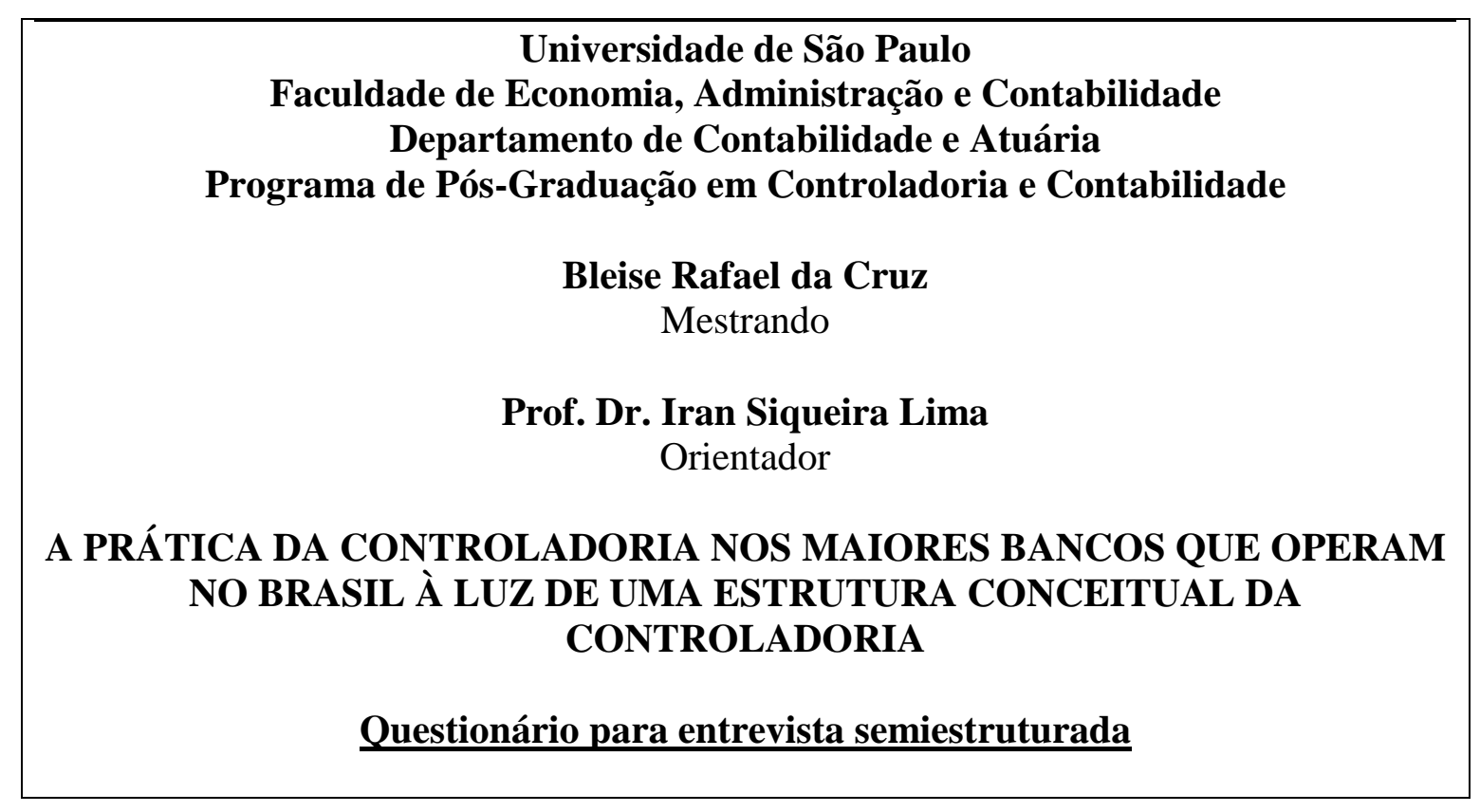

\begin{tabular}{|l|l|}
\hline BLOCO 1 - Identificação da Entrevista \\
\hline Data: & \\
\hline Horário Inicial: & \\
\hline Horário Final: & \\
\hline Local: & \\
\hline Banco: & \\
\hline $\begin{array}{l}\text { Nome do } \\
\text { Entrevistado(a): }\end{array}$ & \\
\hline $\begin{array}{l}\text { Cargo do } \\
\text { Entrevistado(a): }\end{array}$ & \\
\hline
\end{tabular}

\section{BLOCO 2 - Estrutura da Instituição}

Organograma Atual (áreas executivas): 
BLOCO 3 - Identificação da unidade organizacional que exerce funções de Controladoria

1 Há uma unidade denominada Controladoria

2 Caso "Sim", especifique:

Há Controladoria Corporativa?

Há Controladoria Divisional?

Há outro tipo de Controladoria?

Caso "Sim", Favor especificar:

3

Como se denomina o cargo do responsável pela unidade organizacional de Controladoria?

4 A Controladoria é centralizada em um único órgão?

5 Caso "Não", favor responder:

Quantos órgãos denominados Controladoria existem?

A Controladoria é segmentada por "Produtos" ou "Serviços" do Banco?

Quais as áreas que possuem um órgão de Controladoria?

Se não há Controladoria, qual a denominação da

6 unidade organizacional que exerce as funções de Controladoria? (pode haver mais de uma)

\begin{tabular}{|l|l|l|}
\hline \multicolumn{3}{|l|}{ BLOCO 4 - Identificação do Profissional da principal unidade de Controladoria } \\
\hline 7 & Em que ano nasceu? & \\
\hline 8 & Em que curso(s) de graduação é formado? & \\
\hline 9 & Em que curso(s) de pós-graduação é formado? & \\
\hline 10 & Há quanto tempo está na função? E na empresa? & \\
\hline 11 & $\begin{array}{l}\text { Foi contratado para essa função ou foi transferido } \\
\text { de outra área? Em caso de transferência, qual a } \\
\text { área anterior? }\end{array}$ & \\
\hline
\end{tabular}




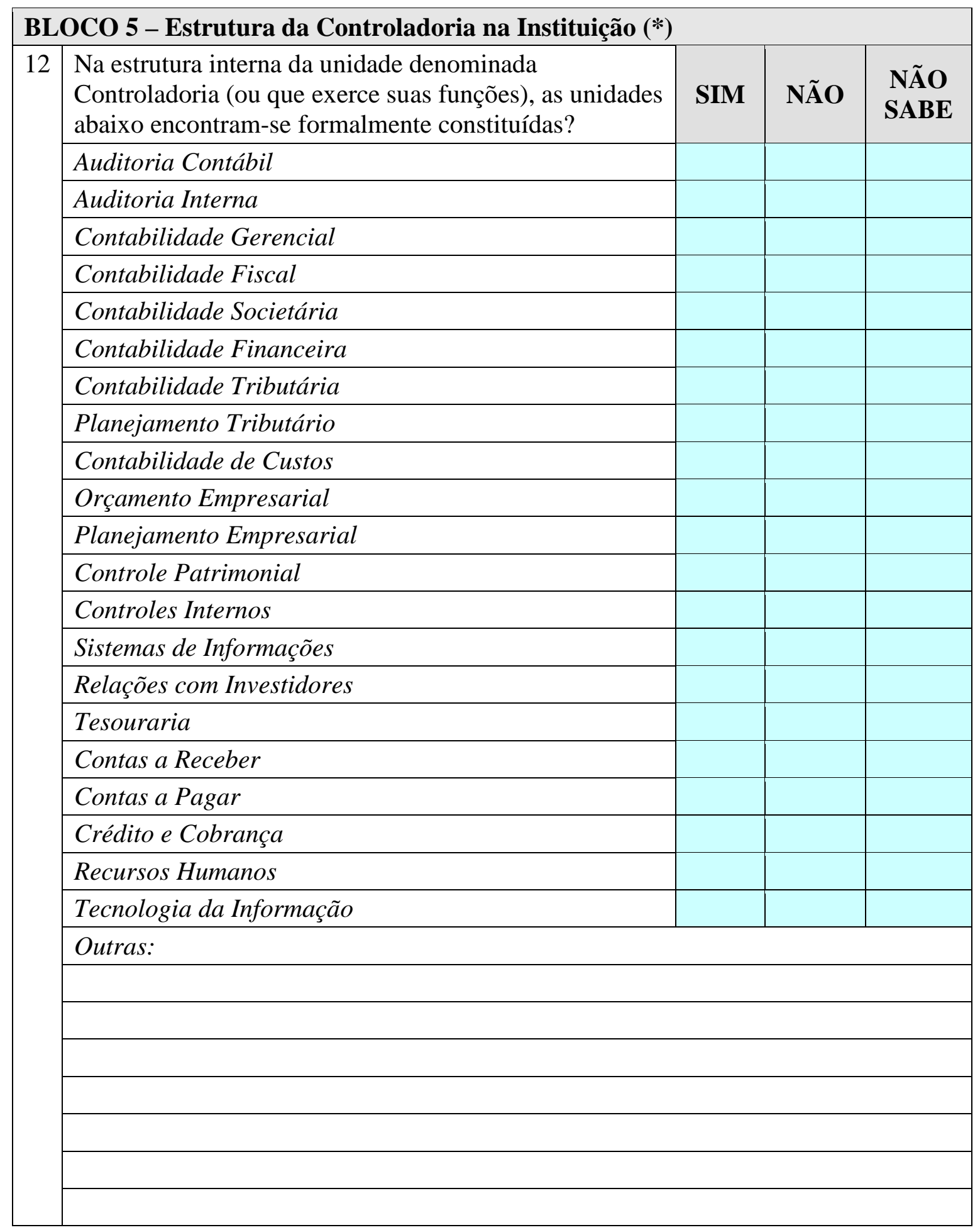

(*) Caso a instituição forneça o organograma interno da área, esta questão não precisa ser respondida. 


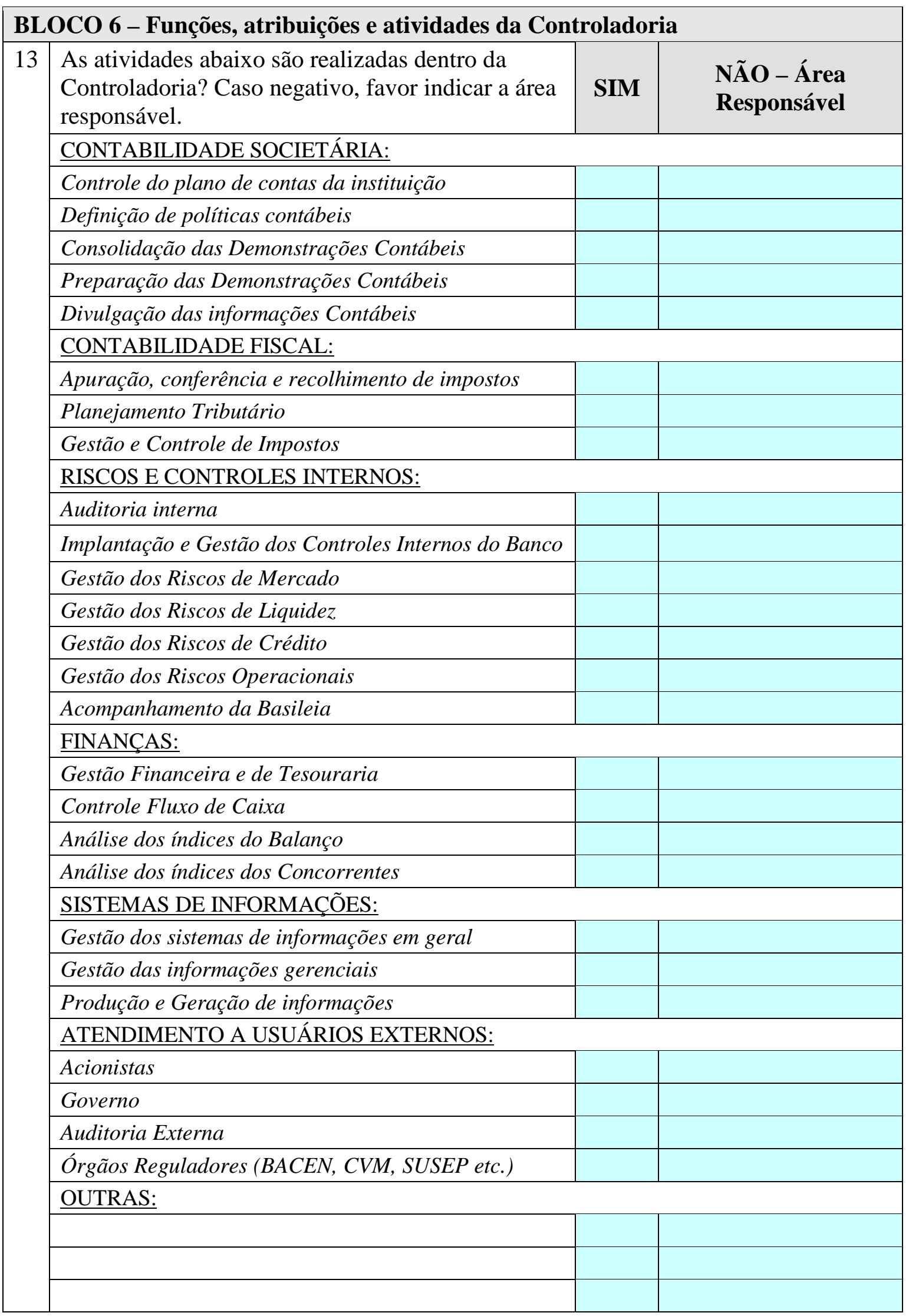




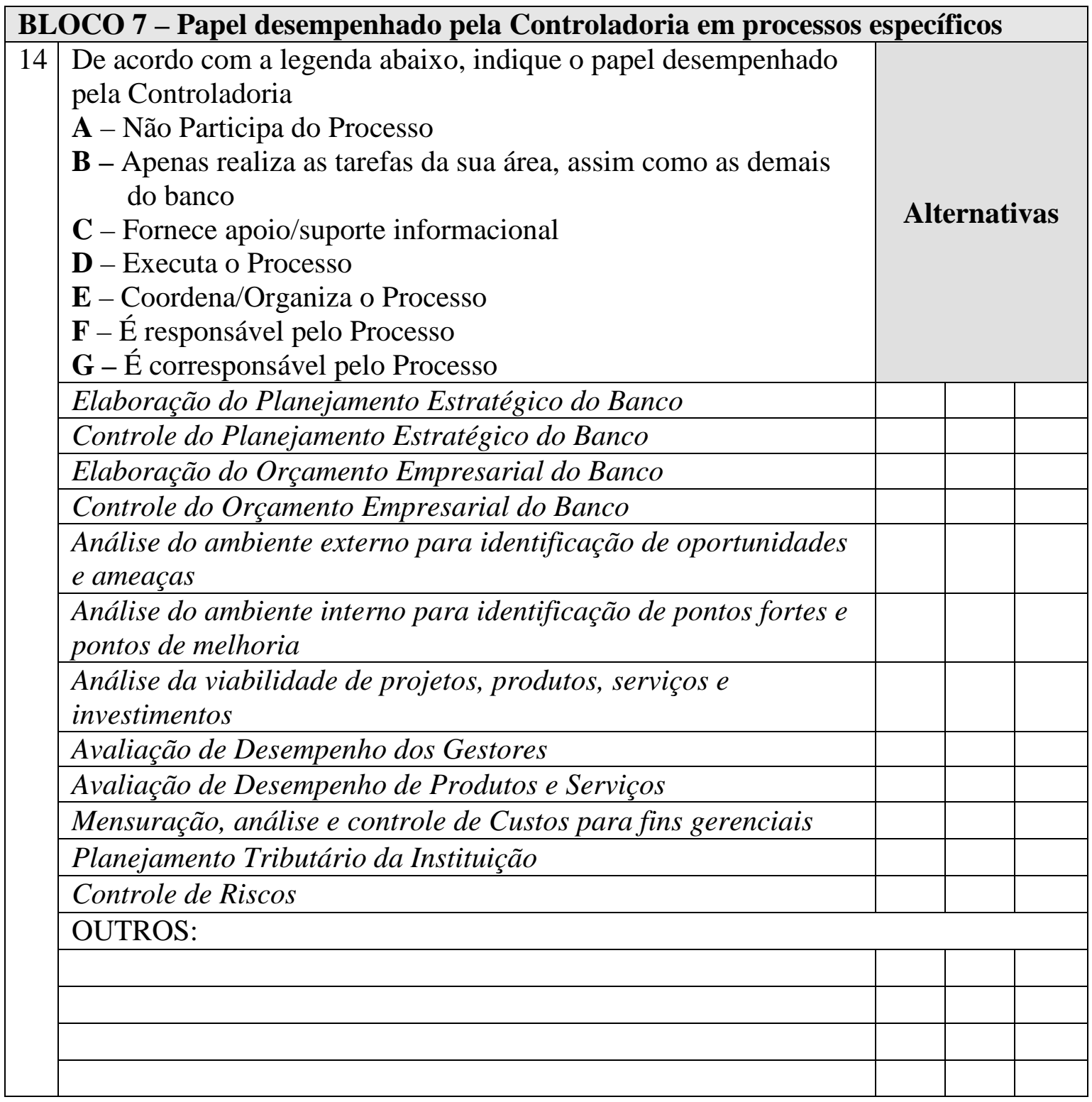

\begin{tabular}{|l|}
\hline Observações: \\
\hline \\
\hline \\
\hline \\
\hline \\
\hline \\
\hline
\end{tabular}

